Кельчевская Н.Р., Пелымская И.С.

\title{
КОРПОРАТИВНАЯ СОЦИАЛЬНАЯ ОТВЕТСТВЕННОСТЬ ПРОМЫШЛЕННЫХ ПРЕДПРИЯТИЙ В МОНОГОРОДАХ
}

Монография

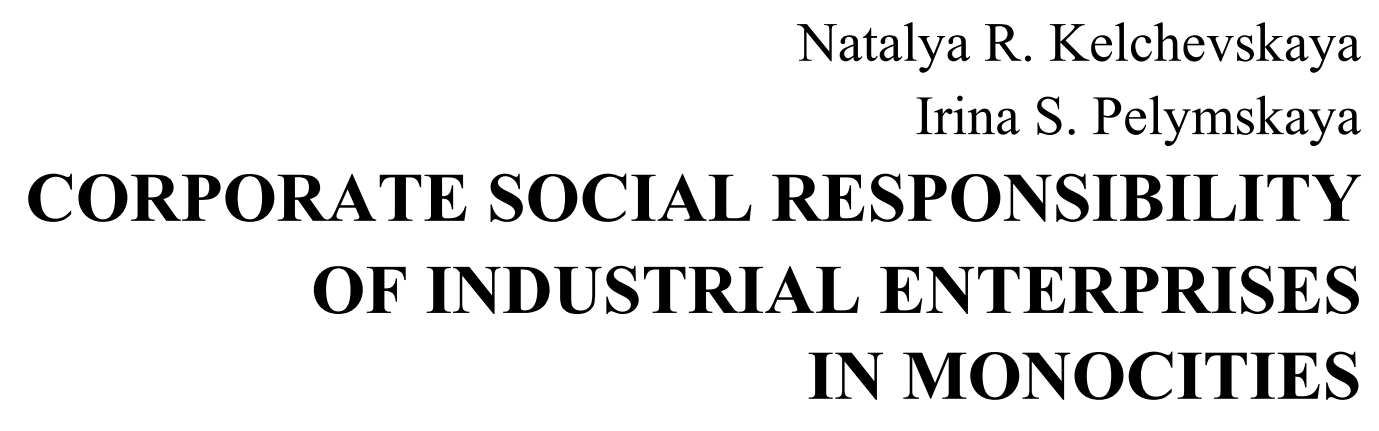

Moscow, 2020

\author{
Москва \\ ПЕРВОЕ ЭКОНОМИЧЕСКОЕ ИЗДАТЕЛЬСТВО \\ 2020
}


УДК 005.35

ББК 65.29

К34

\section{Рецензенты:}

Мокеева Н.Н. - доцент кафедры финансов, денежного обращения и кредита УрГЭУ-СИНХ, кандидат экономических наук, доцент.

Романова О.А. - главный научный сотрудник отдела региональной промышленной политики и экономической безопасности Института экономики УрО РАН, доктор экономических наук.

\section{Кельчевская Н.Р., Пелымская И.С.}

К34 Корпоративная социальная ответственность промышленных предприятий в моногородах [Текст]: монография / Н.Р. Кельчевская, И.С. Пелымская. - М.: Первое экономическое издательство, 2020. - 162 с.

ISBN 978-5-91292-340-1

DOI 10.18334/9785912923401

ISBN 978-5-91292-340-1 Кельчевская Н.Р., Пелымская И.С., 2020

(C) Оформление, дизайн обложки ООО «Первое экономическое издательство», 2020 


\section{СОДЕРЖАНИЕ}

ВВЕДЕНИЕ

1. ТЕОРЕТИЧЕСКИЕ ОСНОВЫ КОРПОРАТИВНОЙ СОЦИАЛЬНОЙ ОТВЕТСТВЕННОСТИ ПРОМЫШЛЕННЫХ ПРЕДПРИЯТИЙ И ЕЕ ОСОБЕННОСТИ В МОНОГОРОДАХ .10

1.1. Сущность корпоративной социальной ответственности предприятий в современных условиях

1.2. Эволюция концепции модели корпоративной социальной ответственности 19

1.3. Нормативно-правовое регулирование корпоративной социальной ответственности организаций в Российской Федерации .41

1.4. Методические подходы к анализу и оценке эффективности корпоративной социальной ответственности предприятий .....47

2. АНАЛИЗ УРОВНЯ РАЗВИТИЯ КОРПОРАТИВНОЙ СОЦИАЛЬНОЙ ОТВЕТСТВЕННОСТИ ПРОМЫШЛЕННЫХ ПРЕДПРИЯТИЙ МОНОГОРОДОВ РОССИЙСКОЙ ФЕДЕРАЦИИ .60

2.1. Особенности корпоративной социальной ответственности промышленных предприятий в моногородах 60

2.2. Российские моногорода: социально-экономическое положение, население и отраслевая специализация предприятий

2.3. Анализ уровня развития корпоративной социальной ответственности промышленных градообразующих предприятий России .78

3. РАЗРАБОТКА МЕТОДИЧЕСКОГО ИНСТРУМЕНТАРИЯ РАЗВИТИЯ КОРПОРАТИВНОЙ СОЦИАЛЬНОЙ ОТВЕТСТВЕННОСТИ ПРОМЫШЛЕННЫХ ПРЕДПРИЯТИЙ В МОНОГОРОДАХ 
3.1. Подход к выбору экономических показателей для оценки состояния корпоративной социальной ответственности промышленного градообразующего предприятия....................102

3.2. Социальное проектирование как методический инструментарий развития корпоративной социальной ответственности промышленных предприятий в моногородах

3.3. Апробация разработанного инструментария развития корпоративной социальной ответственности и расчет экономической эффективности его внедрения

СПИСОК ИСПОЛЬЗОВАННЫХ ИСТОЧНИКОВ 147

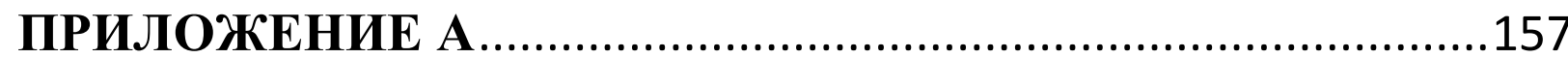

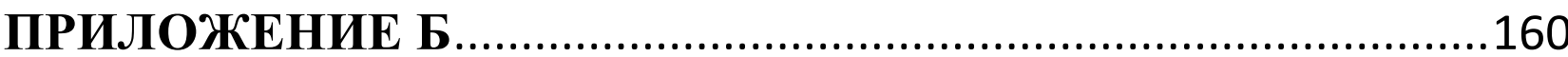


Монография посвящена развитию корпоративной социальной ответственности промышленных предприятий в моногородах. Проблема эффективного ведения социально направленного бизнеса градообразующими предприятиями является наиболее значимой и актуальной для современного общества, так как деятельность этих предприятий напрямую влияет на поддержание устойчивого развития моногорода и комфортность проживания в нем.

В монографии исследуются основные теоретические и практические аспекты корпоративной социальной ответственности градообразующих промышленных предприятий, авторами определены и развиты методические подходы к развитию социальной ответственности промышленных предприятий в моногородах.

Монография может быть полезна студентам, аспирантам, экономистам, руководителям предприятий и практическим работниками в области корпоративной социальной ответственности.

Ключевые слова: корпоративная социальная ответственность, моногород, промышленное предприятие, экономическая эффективность, развитие, анализ, исследование. 



\section{ВВЕДЕНИЕ}

В Российской Федерации значительная часть населения (более 10\% населения страны) проживает в моногородах, которые существенно зависят от функционирования и развития градообразующих предприятий. Как известно, под моногородом или монопрофильным городом понимается муниципальное образование, в развитии которого важную роль играет градообразующее предприятие, обеспечивая население необходимыми социальными благами.

С точки зрения экономики предприятий градообразующего комплекса значительную роль играет корпоративная социальная ответственность (далее - КСО), которая является инструментом поддержания конкурентоспособности, а также формирования модели внешней и внутренней среды организации. Вследствие этого проблема эффективного ведения социально направленного бизнеса градообразующими предприятиями является наиболее значимой и актуальной для современного общества, так как деятельность этих предприятий напрямую влияет на поддержание устойчивого развития моногорода и комфортность проживания в нем.

Цель данной монографии заключается в исследовании специфики корпоративной социальной ответственности градообразующих предприятий и разработке инструментария развития КСО промышленных предприятий в моногородах.

Для достижения поставленной цели определен ряд задач:

- изучить теоретические и методические основы корпоративной социальной ответственности промышленных предприятий;

- проанализировать и оценить уровень развития корпоративной социальной ответственности промышленных предприятий моногородов РФ;

- разработать методику развития корпоративной социальной ответственности промышленных предприятий в моногородах. 
Объект исследования - механизмы реализации корпоративной социальной ответственности на промышленных предприятиях в моногородах.

Предмет исследования - экономические и управленческие отношения, возникающие при реализации корпоративной социальной ответственности градообразующими предприятиями.

Для изучения данного вопроса были использованы методы исследования:

а) проведен контент-анализ литературы;

б) проведен анализ статистических данных в области КСО градообразующих предприятий и данных социально-экономического положения моногородов РФ;

в) в качестве апробации, была исследована деятельность промышленного градообразующего предприятия, а также социальноэкономическое положение г. Верхняя Салда за последние 10 лет и проанализированы такие показатели, как:

1) динамика численности населения моногорода и среднегодовой численности работников градообразующего предприятия;

2) изменение объемов реализации выпускаемой продукции исследуемого предприятия;

3) изменение выручки от реализации исследуемого предприятия и иные виды прибыли;

4) корпоративная документация по деятельности исследуемого предприятия в рамках корпоративной социальной ответственности;

г) проведена оценка эффективности разработанного инструментария. 
Теоретической основой работы являются фундаментальные положения экономической теории, труды отечественных и зарубежных ученых, нормативно-правовые акты РФ, учебная и научная литература, печатные периодические издания и интернет-ресурсы.

Большой вклад в развитие основ теории и изучения различных аспектов корпоративной социальной ответственности внесли Г. Боуэн, А. Кэрролл, К. Девис, Д. Виндзор, А. Зарецкий, Т. Иванова, М. Измайлова, Ю. Благов, О. Данилова, Э. Коротков, П. Робинс, М. Коултер, Н. Петров, А. Титков, Б. Штопов, Л. Фиглин, В. Мосейко, Д. Грейсон, А. Ходжес, Г. Тульчинский, В. Шитов, О. Цымбалист, Е. Попова, И. Черненко и другие авторы.

В качестве эмпирической базы для проведения исследования были использованы данные из открытых источников промышленных градообразующих предприятий на территории Российской Федерации, а также статистические данные по моногородам РФ, размещенные на официальном сайте Федеральной службы государственной статистики.

Монография состоит из введения, теоретической, аналитической и практической главы, заключения, списка использованных источников и приложений. 


\section{1. ТЕОРЕТИЧЕСКИЕ ОСНОВЫ КОРПОРАТИВНОЙ СОЦИАЛЬНОЙ ОТВЕТСТВЕННОСТИ ПРОМЫШЛЕННЫХ ПРЕДПРИЯТИЙ И ЕЕ ОСОБЕННОСТИ В МОНОГОРОДАХ}

\section{1. Сущность корпоративной социальной ответственности предприятий в современных условиях}

В современных условиях экономики одним из наиболее эффективных инструментов повышения конкурентоспособности и инвестиционной привлекательности предприятия является социально ответственная деятельность компании. Вопросам корпоративной социальной ответственности в настоящее время уделяется все больше внимания как в обществе, на предприятиях, так и на уровне государства.

Проблемы социальной ответственности предприятий вызывают большой интерес среди ученых. Это обусловлено недостаточной разработанностью многих вопросов в данной области. Исследованием вопросов социально ответственного поведения компаний занимаются как зарубежные, так и отечественные авторы.

Разработка любого подхода к осуществлению КСО базируется на добровольном принятии на себя обязательств предприятием по безвозмездной реализации различных социальных программ и мероприятий [1]. Основы становления и развития концепций «корпоративная социальная добросовестность», «социальная ответственность бизнеса» и «корпоративная социальная ответственность» изначально зарождались в США.

Первые упоминания о корпоративной социальной ответственности относятся к 50-м годам XX века. Так, американский экономист Говард Боуэн впервые использовал понятие КСО и фактически внес его в научную литературу в 1953 году. Он отметил важность влияния социальных вопросов на развитие экономических показателей орга- 
низации, а также полагал, что социальная ответственность предприятий заключается в реализации такой политики, таких принятий решений и следовании такого поведения, которые являлись бы желательными с позиции ценностей и целей общества [2]. Он отмечал, что феномен социальной ответственности корпорации представляет собой некий акт филантропии, который определен стремлением общества поддерживать свои ценности. В связи с тем, что любые обязательства корпорации необходимы для достижения целей общества, как полагал Говард Боуэн, складывалось мнение, что КСО является обязательной и отказываться от нее совсем было бы нерационально.

Становление и развитие аналогичных теорий, а также их систематизация отражены в работах А. Кэрролла, К. Девиса, Д. Виндзора.

Помимо Г. Боуэна основоположником концепции корпоративной социальной ответственности также является А. Кэрролл, который трактовал корпоративную социальную ответственность как соответствие правовым, экономическим, этическим и дискреционным ожиданиям общества, предъявляемым организацией в данный период [3, 4]. Также он представил такую ответственность в модели «трех кругов» (Three-dimensional Model) [5]:

- внешний круг указывал на возрастание социальных обязательств, возникающих в динамике социального развития;

- средний - определял дополнительные функции менеджмента, которые могли бы повлиять на общественные ценности;

- внутренний - описывал достижение эффектов экономической и иной деятельности.

Позднее А. Кэрроллом была предложена пирамида социальной ответственности, которая послужила основой концепции стейкхолдеров и определила понимание природы социальной активности организаций (рис. 1). 


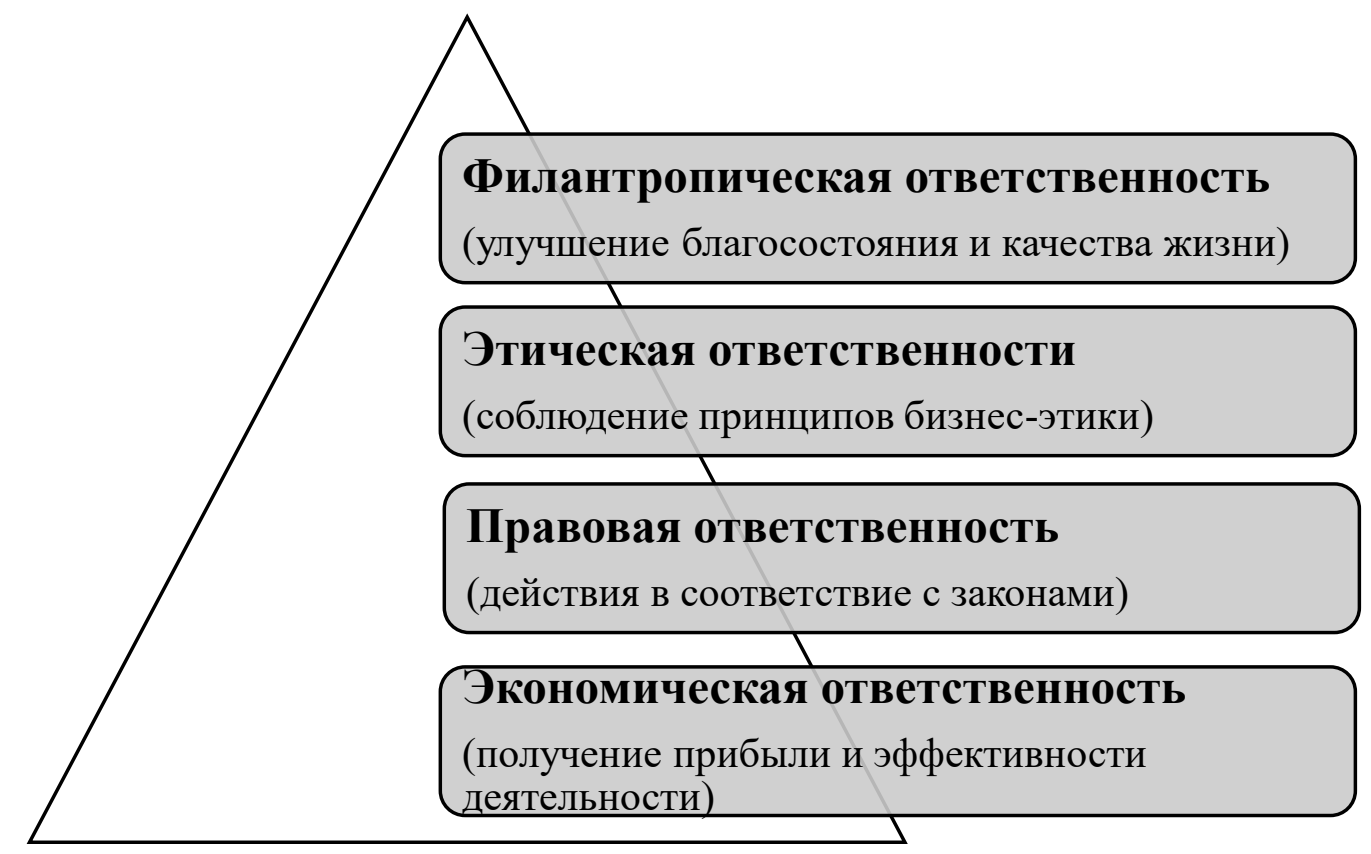

Рисунок 1. Пирамида корпоративной социальной ответственности, согласно Д. Кэрроллу [6, с. 74]

Последователи А. Кэрролла отмечали, что модель «трех кругов» и пирамида социальной ответственности являются универсально применимыми и адаптируемыми под требования корпоративного развития, но также выделяли и существование недостатков этих моделей. Данные модели предполагали возможность определения приоритетов в социальной политике предприятиями самостоятельно, что нередко нарушало баланс в развитии определенных социальных направлений: каким-то направлениям фирмы уделяли достаточно внимания, подавляя традиционное представление бизнес-этики, филантропической деятельности и т. д., при этом некоторые направления оставались нерешенными, что могло вызывать обострение социальных проблем.

Концепция КСО, предложенная К. Девисом, строится на следующих принципах [7]: 
- предприятия должны быть открытыми и прозрачными перед общественностью, осуществляя свою деятельность, а также быть мотивированы рыночными инструментами;

- тщательный расчет списания части себестоимости выпускаемой продукции и оказания услуг на социальные затраты;

- направление развития корпоративной социальной ответственности диктуется общественностью, а государство, в свою очередь, должно создавать для этого все условия и быть наглядным примером социальной ответственности.

Виндзор Д. в своих исследованиях определил, что концепция корпоративного гражданства и управление заинтересованными сторонами являются альтернативными [8].

В экономической литературе также существуют другие различные определения понятия корпоративной социальной ответственности бизнеса. В таблице 1 приведены основные трактовки отечественных и зарубежных авторов по определению корпоративной социальной ответственности.

Таблицุа 1

\section{Трактовки понятия «корпоративная социальная ответственность» и «социальная ответственность»}

\begin{tabular}{|l|l|}
\hline \multicolumn{1}{|c|}{ Автор } & \multicolumn{1}{|c|}{ Определение } \\
\hline Зарецкий А.Д., & Социальная ответственность - это выполнение организа- \\
Иванова Т.Е. & цией законодательно установленных, добровольно приня- \\
{$[9]$} & $\begin{array}{l}\text { тых социальных обязательств по отношению к персоналу, } \\
\text { развитию социально-трудовой сферы внутри компании } \\
\text { и социальной сферы общества и местного сообщества, } \\
\text { на территории которого она осуществляет деятельность }\end{array}$ \\
\hline $\begin{array}{l}\text { Измайлова М.А. } \\
{[10]}\end{array}$ & $\begin{array}{l}\text { Социальная ответственность - базовая ценность общества } \\
\text { и инструмент решения системы социально-экономических } \\
\text { задач }\end{array}$ \\
\hline
\end{tabular}




\begin{tabular}{|c|c|}
\hline $\begin{array}{l}\text { Благов Ю.В. } \\
\text { [11] }\end{array}$ & $\begin{array}{l}\text { Корпоративная социальная ответственность - концепция, } \\
\text { в соответствии с которой предприятие учитывает интересы } \\
\text { общества, принимая на себя ответственность за влияние } \\
\text { и последствия ее деятельности на работников, контраген- } \\
\text { тов, акционеров, местные сообщества и другие заинтерес-- } \\
\text { ванные стороны общественной сферы предприятия. Данная } \\
\text { ответственность действует за рамками законодательно } \\
\text { установленных обязательств и предполагает, что предприя- } \\
\text { тие берет на себя ответственность по повышению качества } \\
\text { жизни сотрудников, их семей и общества }\end{array}$ \\
\hline $\begin{array}{l}\text { Данилова О.В. } \\
{[12]}\end{array}$ & $\begin{array}{l}\text { Корпоративная социальная ответственность - деятельность } \\
\text { компании, направленная на создание стабильной и устой- } \\
\text { чивой экономической среды; интеллектуализация человече- } \\
\text { ского капитала }\end{array}$ \\
\hline $\begin{array}{l}\text { Коротков Э.М. } \\
{[13]}\end{array}$ & $\begin{array}{l}\text { Корпоративная социальная ответственность - реализация } \\
\text { интересов организации путем обеспечения развития ее кол- } \\
\text { лектива и участия компании во всестороннем развитии об- } \\
\text { щества }\end{array}$ \\
\hline $\begin{array}{l}\text { Робинс П., } \\
\text { Коултер М. } \\
{[14]}\end{array}$ & $\begin{array}{l}\text { Корпоративная социальная ответственность - это некое обя- } \\
\text { зательство предприятия преследовать полезные цели обще- } \\
\text { ства в долгосрочном периоде, которое принято им за преде- } \\
\text { лами требуемого законодательства и условий экономики }\end{array}$ \\
\hline $\begin{array}{l}\text { Петров Н.Г, } \\
\text { Титков А.В. } \\
{[15]}\end{array}$ & $\begin{array}{l}\text { Корпоративная социальная ответственность может пони- } \\
\text { маться узко, как забота о социальном обществе, как вложе- } \\
\text { ния в рабочую силу, человеческий капитал через фонды об- } \\
\text { щественного потребления, а также может пониматься ши- } \\
\text { роко - как удовлетворение потребностей социума и служе- } \\
\text { ние обществу }\end{array}$ \\
\hline $\begin{array}{l}\text { Шпотов Б.М. } \\
{[16]}\end{array}$ & $\begin{array}{l}\text { КСО компании - максимизация использования преиму- } \\
\text { ществ фирмы и минимизация ее недостатков, которые непо- } \\
\text { средственно затрагивают участников бизнеса и общество } \\
\text { в целом }\end{array}$ \\
\hline $\begin{array}{l}\text { Фиглин Л., } \\
\text { Мосейко В. } \\
{[17]}\end{array}$ & $\begin{array}{l}\text { Под социальной ответственностью понимается способность } \\
\text { компании оценивать последствия своей деятельности } \\
\text { для развития общества. В широком смысле КСО охватывает } \\
\text { и такие проблемы, как экология, социальная справедли- } \\
\text { вость, равноправие и благосостояние общества }\end{array}$ \\
\hline $\begin{array}{l}\text { Grayson D., } \\
\text { Hodges A. } \\
{[18]}\end{array}$ & $\begin{array}{l}\text { КСО - ответственность предприятия перед контрагентами, } \\
\text { персоналом и другими заинтересованными лицами обще- } \\
\text { ственной среды компании }\end{array}$ \\
\hline
\end{tabular}


Таким образом, обобщив все приведенные выше интерпретации определения корпоративной социальной ответственности, можно сделать вывод, что они схожи по следующим параметрам:

- устойчивое развитие общества является одной из главных задач корпоративной социальной ответственности;

- КСО должна учитывать интересы всех заинтересованных сторон, как внутренних, так и внешних, для повышения качества жизни общества;

- необходима интеграция КСО в стратегию развития предприятий для их более эффективной и качественной деятельности;

- соблюдение концепции и принципов корпоративной социальной ответственности способствует ее более эффективному развитию, улучшению финансовых результатов, повышению безопасности и устойчивости бизнеса.

Исходя из рассмотренных точек зрения авторов различных периодов времени, видно, что более чем за 60 лет становления концепции корпоративной социальной ответственности определены основные принципы социально направленного бизнеса.

Тем не менее помимо первоначальных основ, заложенных в понятие социальной ответственности, с возникновением и формированием новых социально-экономических явлений, появившихся с глобализацией мирового хозяйства, подходы к трактовке КСО были значительно переосмыслены и расширены [19]. Появились систематизированные концепции «этики бизнеса» и концепции «стейкхолдеров» («заинтересованных сторон»). Сама концепция стейкхолдеров отмечает вклад каждой корпорации на индивидуальном уровне, основой принципа является рассмотрение внешней социальной среды во взаимосвязи с прямыми заинтересованными сторонами. Современные подходы к развитию бизнеса направлены на создание улучшенных 
условий жизни для общества внутри и вне предприятий, одновременно достигая экономической эффективности.

В XXI веке предприятиям все сложнее осуществлять социальную ответственность в полной мере в связи с тем, что круг стейкхолдеров непрерывно расширяется, а взаимосвязи с ними усложняются. Несмотря на это, современные исследователи указывают на то, что для развития общества достаточно соблюдения необходимых условий для благополучия и развития самого бизнеса, в связи с этим предприятиям необязательно напрямую прослеживать эффективность своей социальной деятельности в краткосрочной перспективе [20]. Несмотря на это, корпоративная социальная ответственность с технической точки зрения становится традиционным и одним из основных инструментов менеджмента, который рассматривается больше как моральные и этические обязательства.

Определение групп заинтересованных сторон (стейкхолдеров) для каждого из предприятий может осуществляться универсально, тем не менее часть из них могут сочетать в себе несколько функций (к примеру, поставщики могут одновременно являться и потребителями, а работники организации могут выступать акционерами), а также при необходимости можно формировать новые группы стейкхолдеров, объединяя их интересы по направлениям [21, 22]. Далее определим особенности каждой группы заинтересованных сторон:

- одной из наиболее значительных групп заинтересованных сторон являются работники предприятия, штатные (постоянные) или временные. Большинство организаций без трудностей определяют выгоды от ведения социально направленного бизнеса для своих сотрудников, полагая, что тем самым они повышают уровень мотивации, непрерывности деятельности и лояльности ценностям предприятия, повышая свою эффективность и прибыльность $[23,24]$. Ряд закономерных последствий, которые влияют на производительность ин- 
теллектуального и физического труда, связанных с различными социальными гарантиями, может быть весьма разнообразен, поэтому корпорации определяют для себя инструменты КСО самостоятельно.

Трудовые отношения базируются на соблюдении прав человека и трудового законодательства. Решение проблем во взаимоотношениях с данной группой стейкхолдеров относится скорее к базовому уровню корпоративной социальной ответственности компании. Наиболее развитые социальные технологии предполагают инновационные тактики и подходы по улучшению взаимодействия с персоналом. К таким инструментам можно отнести: предоставление льготного или бесплатного доступа к социальной инфраструктуре, развитие социальных гарантий по медицинскому страхованию, превосходящему трудовое законодательство, нематериальные поощрения сотрудников за эффективность работы или поддержание профессионального статуса и т. д. Также необходимо отметить, что отсутствие вложений в социальные обязательства на уровне взаимодействия с работниками влечет за собой значительные риски, поэтому со стороны менеджмента организации необходимо уделять повышенное внимание данной области;

- поставщики и клиенты также являются группой стейкхолдеров ближайшего окружения организации, в интересах которых используются такие практики КСО, как добросовестное и прозрачное ведение дел с целью повышения доверия к деятельности предприятия. Для работы с данной группой заинтересованных сторон руководству компании необходимо создать такое позиционирование финансовой, производственной, технологической, а также социальной устойчивости организации на всех уровнях для увеличения своей привлекательности и конкурентоспособности в рамках обеспечения долгосрочных партнерских отношений. Для реализации мероприятий по работе с поставщиками и клиентами разделяют такие типы рынков, как business to business и business to consumer, включающие в себя определенные 
элементы маркетинга, но также ориентированные на этическое взаимоотношение и стремление превосходить ожидания клиентов в социальной сфере взаимодействия с ними. В связи с этим для данной группы заинтересованных сторон необходимо создание эффективных коммуникационных связей и каналов на уровне маркетинга [25];

- также важнейшими стейкхолдерами для любой организации являются акционеры и инвесторы, которые обеспечивают входной поток заемного или привлеченного капитала. Для данной группы стейкхолдеров необходимо отражать инвестиционную привлекательность предприятия, эффективность разработанной стратегии по долгосрочному развитию и перспективность его деятельности. Для обеспечения надежных отношений с данной группой заинтересованных лиц мероприятия КСО должны быть ориентированы на раскрытие достоверной информации экономической и социальной деятельности предприятия, а также поддержание эффективности работы коммуникационных каналов предприятия, при этом они должны быть направлены как на существующих партнеров, так и на потенциальных инвесторов;

- локальное сообщество, представляющее собой группу стейкхолдеров, которые прямо или косвенно взаимосвязаны с деятельностью предприятия. Данная группа может быть не ограничена географическим фактором, так как их интересы группируются благодаря различным средствам коммуникации и технологиям. Такая категория стейкхолдеров может включать в себя людей, на экологическое благополучие которых влияет деятельность предприятия (особенно промышленность), косвенные потребители продукции или услуг фирмы, члены сообщества, исследующих экологические, технологические или экономические аспекты общества, другие лица и сообщества.

Естественно, что набор всех стейкхолдеров весьма широк, а их интересы чрезвычайно разнообразны, а в некоторых случаях бывают 
несовместимы или противоположны. В подобных случаях на практике социальной направленности финансовых вложений значимое место занимает содействие в развитии отношений со стейкхолдерами и в повышении качества социальной инфраструктуры (как это происходит на крупных промышленных предприятиях в российских моногородах).

\section{2. Эволюция концепции модели корпоративной социальной ответственности}

В связи с многообразием определений КСО необходимо обратиться к истории становления концепции модели корпоративной социальной ответственности. Процессы становления зрелых индустриальных экономик в течение предшествующего столетия привели к социально-экономическим изменениям, вследствие которых существенно расширилось понимание принципов функционирования коммерческих организаций, признаками эффективности работы которых стало не только наличие прибыли как важнейшего финансового результата, но и принятие и исполнение ряда обязательств в отношении общества, с которым взаимодействуют. Стратегия формирования и развития долгосрочных отношений с заинтересованными сторонами с течением времени стала рассматриваться как конкурентное преимущество, возможность ясно демонстрировать обществу намерения компании в области основных направлений развития, тем самым повышая уровень доверия к своей деятельности и качество социального капитала. Таким образом, члены общества наряду с непосредственно заинтересованными сторонами (работники, акционеры, партнеры, конкуренты) получают доступ к информации в сфере принципов и результатов работы отдельных организаций, а в иных случаях даже оказывают прямое влияние на поощрение или ограничение некоторых видов организационной деятельности. 
Проблемы корпоративной социальной ответственности остаются весьма актуальными для многих исследователей, поскольку представляют собой путь к решению комплексных задач, стоящих перед представителями современного бизнеса и общества. Логика процесса становления концепции социальной ответственности при значительном объеме исследований по данному направлению неоднозначна, однако наибольшим толчком к ее развитию стало осознание социальной природы организаций и ее значимости с точки зрения расширяющегося круга заинтересованных сторон. В современный период вопросы социальной ответственности касаются любой организации, и разработка любого практического инструментария социальной ответственности и социального инвестирования требует изучения теоретического фундамента данных направлений деятельности организаций. С этой целью необходимо изучить процессы развития концепции в зарубежной и отечественной литературе. Еще в начале XIX в. Р. Оуэн одним из первых говорил о проблеме элементарной ответственности менеджмента как совокупности отдельных личностей, применяющих человеческие и иные ресурсы для достижения корпоративных целей. Теоретико-методические основы концепции социальной ответственности можно проследить и в работах классических экономистов, таких как Дж.С. Милль, Ж.Б. Сэй, К. Маркс и др., исследования авторов касались вопросов производительного труда и факторов, его определяющих, установления социальной справедливости при распределении ресурсов между различными сторонами экономических процессов. В экономико-философских работах К. Маркса, несмотря на обширную современную критику, заложены острые вопросы, которые не раз будут возникать у исследователей социальной ответственности в течение всех последующих десятилетий, например о том, насколько эффективно с социальной точки зрения используются экономические ресурсы и как происходит их распределение между заинтересованными сторонами. Выработка любого подхода к осуществлению корпоративной социальной ответственности 
основывается, прежде всего, на современном понимании ее принципов и развития этого понятия в зарубежной управленческой мысли. Основой таких принципов по общему определению является добровольное взятие предприятием на себя обязательств по выполнению различного рода социальных программ на безвозмездной основе. Первоначально данный принцип развивался, прежде всего, в США, являясь основой таких концепций, как социальная ответственность бизнеса, корпоративная социальная ответственность, корпоративная социальная добросовестность. Руководство компаний на интуитивном уровне начало приходить к выводу, что поддержание социальной активности так же важно, как и получение прибыли, и является ключом к устойчивому развитию. В 1953 году вышла работа Г. Боуэна «Социальная ответственность бизнесмена». Согласно Г. Боуэну, социальная ответственность состоит в принятии таких решений, которые бы определяли линию поведения компании, желательную и благоприятную для целей и ценностей общества. Исследователь отмечал, что феномен социальной ответственности корпораций представляет собой акт филантропии, который продиктован стремлением сообществ поддержать свои ценности [2]. Боуэн также полагал, что любые обязательства бизнеса желательны для достижения целей и задач общества, таким образом, складывалось впечатление, что социальная ответственность обязательна и было бы нерациональным шагом отказываться от нее вовсе. В монографии, принесшей автору заслуженную славу «отца корпоративной социальной ответственности», во многом были определены рамки и заданы направления последующей дискуссии о социальной ответственности бизнеса.

Однако У. Фредерик и К. Дэвис, в свою очередь, полагали, что для каждой организации существуют рациональные предпосылки для проявления в деловых ситуациях социально ответственного поведения, которое в результате может обернуться значительными финансовыми выгодами. 
Обсуждение вопросов социальной ответственности начиная с 1970-х гг. приняло масштабный характер. Мнения исследователей стали радикально расходиться. Дж. Мак Гуир отмечал, что корпорация имеет не только экономические и правовые обязательства, но и несет социальную ответственность перед обществом [7]. Согласно стейкхолдерской модели Р. Фримена, представители менеджмента должны были учитывать интересы и ожидания всех участников, которые связаны с деятельностью предприятий, таким образом, в зону формирования социально ответственной политики предприятия попадают не только работники, но и члены местных сообществ.

В противовес мнений об эффективности социальной ответственности М. Фридман [8] отмечал, что для бизнеса она обеспечивается за счет повышения его прибыли для акционеров, а менеджеры не должны включаться в процессы нецелевого расходования средств предприятий, лежащие за пределами их компетенций. Радикальная точка зрения М. Фридмана подкреплялась еще и тезисом о том, что социальная ответственность не является элементом стратегического преимущества, пока не становятся очевидными и прозрачными выгоды от ее применения. Социальная ответственность эффективна только в том случае, если приносит очевидные выгоды всем заинтересованным сторонам, а для самой корпорации самой очевидной выгодой является, прежде всего, прибыль от деятельности.

Формирование единого поля социальной ответственности предполагало, что социальная активность осуществляется и при ведении внешних операций (от рыночной деятельности до обеспечения технологического обмена и создания инноваций) и в плане внутренней деятельности (то, как предприятие распоряжается привлекаемой рабочей силой, какие обязательства возникают перед работниками и т.п.). Д. Кэрролл в этих условиях описал ответственность в модели «трех кругов» (Three-dimensional Model): внутренний круг описывал достижение экономических эффектов, средний круг означал опосредующие 
функции менеджмента, влияющие на развитие ценностей общества, внешний круг обозначал возрастающие социальные обязательства, которые возникают в динамике социального развития [5]. Немного позднее Д. Кэрроллом была предложена пирамида социальной ответственности, которая внесла вклад в развитие концепции стейкхолдеров и понимание природы социальной активности предприятий. Лежащая в основании пирамиды экономическая ответственность непосредственно определяется базовой функцией компании на рынке как производителя товаров и услуг, позволяющих удовлетворять потребности потребителей и, соответственно, извлекать прибыль. Правовая ответственность подразумевает необходимость законопослушности бизнеса в условиях рыночной экономики, соответствие его деятельности ожиданиям общества, зафиксированным в правовых нормах.

Этическая ответственность, в свою очередь, требует от деловой практики созвучности ожиданиям общества, не оговоренным в правовых нормах, но основанным на существующих нормах морали. Филантропическая ответственность побуждает компанию к действиям, направленным на поддержание и развитие благосостояния общества через добровольное участие в реализации социальных программ.

Теория «корпоративного эгоизма» указывает, что единственная ответственность бизнеса - увеличение прибыли для своих акционеров. Главный ее представитель, как уже известно, Милтон Фридман (1970). Этой же позиции придерживался Т. Левитт (1958), который также выступал против корпоративной ответственности перед обществом, мотивируя это тем, что подобная ответственность уводит бизнес в сторону от его основной цели - получения прибыли.

Вторая точка зрения, получившая название теории корпоративного альтруизма, прямо противоположна теории М. Фридмана и появилась одновременно с его публикациями. Основная идея заключается в том, что бизнес должен заботиться не только о росте прибыли, но и делать максимально доступным вклад в решение общественных 
проблем, повышение качества жизни граждан и сообщества, а также в сохранение окружающей среды. Авторство этой теории принадлежало Комитету по экономическому развитию США. В рекомендациях Комитета подчеркивалось, что «корпорации обязаны вносить значительный вклад в улучшение качества американской жизни». Основателем этой теории можно считать Г. Боуэна (1953), также ее придерживались С. Сети (1975), Д. Вуд и др. Они говорили о том, что компании не могут самоустраняться от социальных проблем, так как они являются открытыми системами, активно участвуя в лоббировании законов и других государственных решений, спонсируя различные партии и иные общественные объединения.

Третья позиция представлена одной из самых сильных «центристских» теорий, теорией «разумного эгоизма» (enlightened selfinterest). Ее поддерживали К. Дэвис (1960), У. Фредерик, Дж. Мак Гуир и др. Она строится на том, что социальная ответственность бизнеса - это просто «хороший бизнес», поскольку сокращает долгосрочные потери прибыли. Затраты на социальные и благотворительные программы сокращают текущую прибыль, но в долгосрочной перспективе создают благоприятное социальное окружение и, следовательно, устойчивые прибыли. Филантропические и спонсорские программы способствуют узаконенному снижению налогооблагаемой базы компании и дают хороший «эффект публичности». Именно в этом состоит основной мотив социальной деятельности компании.

Помимо выделенных разновидностей концепции социально ответственного бизнеса позднее стал выделяться широко распространенный и на сегодняшний день интегрированный подход к социальной ответственности, когда корпоративная социальная ответственность направлена и во внешнюю, и во внутреннюю среду корпорации и идет учет интересов всех заинтересованных сторон. Главными представителями этого подхода считаются Р. Фримен (1984) с его мо- 
делью «стейкхолдеров» (по Фримену, «стейкхолдер - это группа (индивидуум), которая может оказать влияние на достижение организацией своих целей или на работу организации в целом»), Л. Крамер (1995), А. Кэрролл (с 1991 г.) и др. Рассмотренные выше подходы к определению сущности КСО сведены в таблицу 2.

Таблицุа 2

\section{Подходы к определению сущности корпоративной социальной ответственности}

\begin{tabular}{|c|c|c|}
\hline Подход & Авторы & Сущность КСО \\
\hline $\begin{array}{l}\text { Корпоративный } \\
\text { эгоизм }\end{array}$ & $\begin{array}{l}\text { Т. Левитт (1958), } \\
\text { М. Фридман (1970) }\end{array}$ & $\begin{array}{l}\text { - обеспечение экономиче- } \\
\text { ских и финансовых интере- } \\
\text { сов собственников; } \\
\text { - получение высокой при- } \\
\text { были }\end{array}$ \\
\hline $\begin{array}{l}\text { Корпоративный } \\
\text { альтруизм }\end{array}$ & $\begin{array}{l}\text { Комитет по экономиче- } \\
\text { скому развитию США, } \\
\text { Г. Боуэн (1953), } \\
\text { С. Сети (1975), } \\
\text { Д. Вуд (1991) }\end{array}$ & $\begin{array}{l}\text { - социальные обязательства; } \\
\text { - благотворительная прак- } \\
\text { тика; } \\
\text { - социальная практика }\end{array}$ \\
\hline Разумный эгоизм & $\begin{array}{l}\text { К. Дэвис (1960), } \\
\text { Дж. Мак Гуир (1963), } \\
\text { У. Фредерик (1968) }\end{array}$ & $\begin{array}{l}\text { - долгосрочное инвестирова- } \\
\text { ние; } \\
\text { - достижение долгосрочных } \\
\text { преимуществ }\end{array}$ \\
\hline Интегрированный & $\begin{array}{l}\text { Р. Фримен (1984), } \\
\text { А. Кэрролл (с 1991), } \\
\text { Л. Крамер (1995) }\end{array}$ & $\begin{array}{l}\text { - КСО направлен и на внут- } \\
\text { реннюю, и на внешнюю } \\
\text { среду компании; } \\
\text { - идет учет всех заинтересо- } \\
\text { ванных сторон }\end{array}$ \\
\hline
\end{tabular}

Если говорить о целостности модели корпоративной социальной ответственности, то именно подход А. Кэрролла получил широкий резонанс в силе придания логической последовательности концепциям предшественников и определил формы современных экономических 
исследований в области корпоративной социальной ответственности. Как уже упоминалось ранее, по А. Кэрроллу, социальная ответственность бизнеса включает в себя экономические, юридические, этические, а также филантропические ожидания, которые общество предъявляет организации. Сведем все составляющие корпоративной социальной ответственности в таблицу 3.

Таблица 3

\section{Составляющие корпоративной социальной ответственности}

\begin{tabular}{|c|c|}
\hline $\begin{array}{c}\text { Область реализа- } \\
\text { ции }\end{array}$ & Характеристика \\
\hline $\begin{array}{l}\text { Экономическая от- } \\
\text { ветственность }\end{array}$ & $\begin{array}{l}\text { • основная социальная ответственность фирмы; } \\
\text { • доходы должны быть максимизированы; } \\
\text { • в обязанности бизнеса входит предоставление потре- } \\
\text { бителям качественных товаров и услуг по приемлемым } \\
\text { ценам; } \\
\text { • основными общественными проблемами должно за- } \\
\text { ниматься государство в лице различных социальных ин- } \\
\text { ститутов }\end{array}$ \\
\hline $\begin{array}{l}\text { Правовая } \\
\text { ственность }\end{array}$ & $\begin{array}{l}\text { • обязательства бизнеса - подчиняться: } \\
\text { - общим законам для бизнеса; } \\
\text { - уголовным законам; } \\
\text { - специальным, регулирующими деятельность произво- } \\
\text { дителей (например, Закон о защите прав потребителей); } \\
\text { • специальные службы и отделы на предприятиях } \\
\text { для рассмотрения претензий и рекламаций }\end{array}$ \\
\hline $\begin{array}{l}\text { Этическая ответ- } \\
\text { ственность }\end{array}$ & $\begin{array}{l}\text { • моральные обязательства фирмы вести себя этично } \\
\text { и социально ответственно; } \\
\text { • масштаб этических норм шире, но они могут быть не- } \\
\text { обязательны для реализации }\end{array}$ \\
\hline $\begin{array}{l}\text { Дискреционная } \\
\text { (филантропиче- } \\
\text { ская) ответствен- } \\
\text { ность }\end{array}$ & $\begin{array}{l}\text { • участие бизнеса (фирмы) в реализации социальных } \\
\text { программ как на уровне общества, так и на уровне самой } \\
\text { фирмы }\end{array}$ \\
\hline
\end{tabular}


Однако в последнее время подход А. Кэрролла был подвержен жесткой критической оценке, указывая на то, что филантропия не может рассматриваться как ответственность сама по себе, и лучше ее отнести к этической или экономической ответственности, ибо благотворительность основана на этическом аспекте и имеет экономическую мотивацию. Поэтому в 2003 г. «пирамида Кэрролла» обрела форму трехсферной модели, в которой показано взаимодействие и взаимодополнение экономического, юридического и этического аспектов ответственности.

Рассмотрим подробнее составляющие модели Кэрролла:

1. Экономическая ответственность определяет базовую функцию компании как производителя товаров и услуг, позволяющую максимизировать прибыль настолько, насколько возможно, поддерживая сильное конкурентное положение и высокий уровень производительности. Данная категория имеет чисто экономический характер, и основанная на ней деятельность может считаться незаконной или неэтичной. Примером может служить Ford Motor Company, которая продолжала производить автомобили модели Pinto в 1970-х гг., несмотря на наличие опасных дефектов (производители снизили стоимость страхования данной модели, вместо того чтобы прекратить ее производство).

2. Юридическая ответственность подразумевает повиновение или исполнение закона как основных понятий справедливости, установленных законодательством. А. Кэрролл выделяет три типа юридических мотивов: согласие (пассивное, ограничительное, оппортунистическое), уклонение от гражданской тяжбы, ожидание закона. Пассивное согласие подразумевает исполнение определенных требований норм безопасности (если даже это не прописано законом), и компания, придерживающаяся этого, находится в пассивном способе согласия. Ограничительное согласие возникает в случае, когда компа- 
нии вынуждены придерживаться закона. Например, закон может запрещать большее загрязнение, чем установлено нормативами, таким образом, правовая система ограничивает определенного рода деятельность. Оппортунистическое согласие проявляется в действиях компании при соблюдении буквы закона, а не его духа. Компании могут использовать и искать определенные лазейки в законодательстве в целях участия в определенных действиях. Также возможны попытки действовать в специфической юрисдикции, например, организация производства в развивающихся странах с менее строгими экологическими стандартами, более слабым законом защиты потребителей и благосостоянием служащих.

Второй тип юридических мотивов - уклонение от гражданской тяжбы - желание избежать текущей и будущей гражданской тяжбы в результате небрежного поведения. В ответ на такие страхи компании могут прекратить вредные для окружающей среды действия. Часто эти компании участвуют в юридической защитной стратегии, пытаясь уладить все судебные процессы.

В случае же мотива ожидания изменений в законодательстве компании могут участвовать в лоббировании своих интересов при разработке и принятии новых законов.

3. Этическая ответственность требует от деловой практики соответствия ожиданиям общества, основанным на приверженности ряду этических стандартов или моральных принципов.

Однако сложно выделить чисто этические мотивы, потому как невозможно в полной мере знать мотивы принятия решения и их последствия.

Конечно, в идеале социально ответственной компанией может считаться только та, в действиях которой соблюдены нормы и правила всех аспектов ответственного поведения. Однако в современной реальности возможны различные варианты неполного соответствия. 
Наиболее распространенные модели такого поведения компаний представлены ниже:

- этико-экономическая ответственность - сочетание экономической и этической ответственности. К ней можно отнести производство зеленых товаров народного потребления (знаменитые электромобили Smart, уменьшение использования пластиковых упаковок, автоматическое участие в благотворительных акциях при покупке товаров и т.д.). Таким образом, действия компаний экономически и этически обоснованы;

- экономико-правовая ответственность характеризует компании, экономически и юридически ответственные, допускающие некоторое неэтичное поведение, использующие законодательные и административные лазейки для получения экономической выгоды. Например, осуществление деятельности в странах третьего мира - в худших социальных условиях или экологических условиях;

- этико-правовая ответственность характеризует деятельность не из-за прямых экономических выгод, а на основании законодательства и этических принципов. К примеру, мероприятия по установке очистных сооружений требуются по закону и предотвращают негативное воздействие на окружающую среду, здоровье людей на территории присутствия компании, следовательно, такую деятельность можно считать также этичной.

Рассмотренные варианты показывают, что неполная реализация всех видов ответственности приводит к определенным дисфункциям. Особое значение в связи с этим имеет новый подход к корпоративной социальной ответственности А. Кэрролла, который более точно определяет взаимосвязь и неотделимость экономической, правовой и этической ответственности, одномоментное исполнение которых позволяет говорить о высоком уровне социальной ответственности предприятия. В начале XXI в. ООН сформулировала десять принципов Глобального договора, обращенных предпринимательскому сообществу: 
- оказывать поддержку соблюдению прав человека, провозглашенных международным сообществом;

- обеспечить свою непричастность к нарушениям прав человека;

- поддерживать свободу ассоциаций и признавать право персонала на заключение коллективных договоров;

- выступать за уничтожение всех форм принудительного труда;

- выступать за ликвидацию дискриминации в сфере труда и занятости;

- выступать за полное искоренение детского труда;

- способствовать предупреждению негативных воздействий на окружающую среду;

- проявлять инициативы, направленные на повышение ответственности за состояние окружающей среды;

- содействовать развитию и распространению экологически чистых технологий;

- противодействовать коррупции во всех ее формах, включая вымогательство и взяточничество [9].

По сути, эти десять принципов являются концептуальной основой для проведения политики в области корпоративной социальной ответственности каждой фирмой и предприятием в мире. Таким образом, в КСО можно выделить направления развития социально-экономических отношений, частью которых являются социально-трудовые отношения и экологическая безопасность. Необходимо заметить, что включение вопросов защиты экологии в первую очередь произошло под влиянием различных общественных объединений и в результате многочисленных экологических катастроф, самыми известными и оказавшими наибольшее влияние на изменение политики корпораций по отношению к обществу стали: 
- утечка токсичных газов на заводе по производству пестицидов компании Union Carbide в Бхопале (Индия) в 1994 г., в результате которой погибли более 22000 человек;

- катастрофа танкера Valdez компании Exxon у берегов Аляски в 1989 г., приведшая к самому большому разливу нефти в истории Америки - пораженными оказались более 1770 км прибрежной территории, сумма штрафов компании составила 1 млрд долларов;

- обвинения нефтяной компании Shell в нарушении прав коренного населения в долине р. Нигер на территории Нигерии, где компания Shell Nigeria добывала 80\% своей нефти, кроме того, были предъявлены обвинения в финансировании диктаторского режима в стране.

В этом контексте, говоря о включении в КСО вопросов взаимоотношений корпораций с инвесторами и акционерами, эта тенденция особо выделилась после скандалов с крупнейшими американскими компаниями Evron и WorldCom. Инвесторы, акционеры и общество оказались союзниками в процессе формирования и внедрения КСО. Корпоративная социальная ответственность в различных своих проявлениях имеет очень долгую историю в России. Еще до Октябрьской революции предприниматели участвовали в строительстве школ, библиотек и железных дорог, а позже, в советскую эпоху, государственные компании помогали в решении многих социальных задач: предоставление жилья своим рабочим, строительство бассейнов и футбольных полей в регионах своего присутствия [19].

С 1990 г. можно выделить несколько этапов становления модели корпоративной социальной ответственности в России:

1. 90-е гг. - беспорядки в стране, несистемная частная благотворительность.

Первыми проявлениями социально ответственного поведения российского предпринимательства 1990-х гг. были благотворитель- 
ность и меценатство. Но формирование рыночной экономики постепенно привело к расслоению общества (класс богатых и класс бедных). Благотворительность перестала зависеть от основной деятельности предприятий и стала больше личной инициативой самих руководителей предприятий.

2. 2002-2006 гг. - рост активности корпоративной социальной ответственности.

Активность российского бизнеса в сфере КСО началась после 2003 г., когда Президент РФ В.В. Путин призвал российских предпринимателей быть социально ответственными. Процесс активности продолжался вплоть до кризиса 2008 г. Нестабильность экономики показала «истинное» отношение компаний к социально ответственной деятельности: некоторые компании сократили расходы на социальную деятельность или даже отказались от принятых ранее обязательств, а ряд компаний перешли на нефинансовую форму корпоративной социальной ответственности - корпоративное волонтерство, материальная помощь и т.д.

3. 2007 г. - экономический кризис; упадок корпоративной социальной ответственности.

4. 2008 г. - настоящее время - закрепление имеющихся представлений о КСО, привязывание КСО компании к ее основной деятельности, переход к стратегическому планированию. Обсуждение проблем корпоративной социальной ответственности прочно заняло одну из лидирующих позиций как на страницах газет и деловых журналов, так и на повестке дня форумов руководителей государства и лидеров российского бизнеса.

Основными направлениями корпоративной социальной ответственности, отражающими ее российскую специфику, по мнению современных экономистов К.В. Симонова, Д.В. Петросянц, Е.В. Махмутовой, должны являться: 
- политика доходов населения (жизненный уровень, потребительская корзина, благосостояние);

- политика в сфере труда и трудовых отношений (достойная и своевременная оплата труда, охрана труда и социальное страхование, занятость населения);

- социальная поддержка и защита нетрудоспособных и малоимущих слоев населения (пенсионное обеспечение, социальное обслуживание, социальные гарантии и т.п.);

- основные направления развития отраслей социальной сферы (охрана здоровья и его профилактика, обеспечение занятости трудоспособного населения, разработка пенсионных схем, образование, наука, культура, физическая культура и спорт и т.п.);

- обеспечение экологической безопасности социума;

- политика в области современной инфраструктуры (обеспечение жильем и ЖКХ, транспорт, коммуникации, торговое и бытовое обслуживание);

- миграционная политика;

- государственная политика в отношении отдельных категорий населения (семейная, молодежная политика, политика в отношении пожилых и инвалидов и т.п.).

Д.А. Ситковский отмечает, что «социальная ответственность бизнеса представляет собой философию поведения и концепцию выстраивания деловым сообществом, компаниями и отдельными менеджерами основной и дополнительной общественно значимой деятельности. При этом социальная ответственность бизнеса не является и не может рассматриваться в качестве некой операционной, жестко и однозначно регламентированной сферы деятельности. Именно поэтому социальную ответственность бизнеса следует трактовать как стиль деловой активности, принятый бизнесменами добровольно 
и оказывающий значимое влияние на процесс принятия ими стратегических и тактических решений по развитию бизнеса с учетом интересов всех задействованных сторон» [11]. Кроме того, он отмечает, что основные вопросы, связанные с ролью бизнеса в развитии общества, представлены в концепциях так называемой социальной ответственности бизнеса (или корпоративной социальной ответственности). Отметим, что наблюдается одинаковое понимание этих категорий - «социальная ответственность бизнеса» и «корпоративная социальная ответственность».

Как отмечает М.В. Киварина, социальная ответственность бизнеса трактуется по-разному: иногда очень узко, иногда слишком широко. В узком смысле корпоративная социальная ответственность предполагает своевременную выплату работникам зарплаты, уплату налогов, соблюдение законодательства в сфере охраны окружающей среды, техники безопасности и здоровья работников, этичное поведение в рамках существующего законодательства. Следовательно, исходной сферой формирования системы социальной ответственности бизнеса являются социально-трудовые и связанные с ними экономические и политические отношения. С этих позиций социальная ответственность выступает как метод цивилизованного решения социально-трудовых конфликтов, содержащий в себе механизм достижения социальной стабильности общества. В широком смысле корпоративная социальная ответственность представляет собой добровольный вклад бизнеса в развитие общества в социальной, экономической и экологической сферах, зачастую не связанный напрямую с основной деятельностью компании и выходящий за рамки определенного законодательного минимума и принятых в обществе этических норм. Это ответственность перед деловыми партнерами и сотрудниками, перед местными сообществами и населением в целом. 
Что касается отношения власти в лице президента России В.В. Путина к корпоративной социальной ответственности, то на сегодняшний день он призывает предпринимателей обращать больше внимания на так называемую внутреннюю социальную политику предпринимателей, т.е. социальную политику, проводимую для работников своей компании: «Государство должно выстраивать баланс между развитием рыночных отношений, с одной стороны, и вопросами социальной справедливости, - с другой... Социальное партнерство это и взаимная ответственность и работодателей, и работников, и, еще раз повторю, - их объединение» (Президент России В.В. Путин).

Действенным механизмом формирования условий для повышения уровня внутренней корпоративной социальной ответственности бизнеса является институт социального партнерства, в основе которого - диалог и взаимовыгодное сотрудничество работодателей и профсоюзов. Вопросам социального партнерства в сфере труда посвящен целый раздел Трудового кодекса Российской Федерации, занимающий первостепенное место в Законе. Прогрессивно мыслящая часть предпринимателей России принимают этику социальной ответственности бизнеса, осознают, что социальная ответственность в бизнесе - это обязательное условие его развития, а построение отношений с представителями работников - профсоюзами на принципах социального партнерства - главный инструмент повышения уровня социальной ответственности компании.

Рассмотрим становление модели корпоративной социальной ответственности в США. В США о корпоративной социальной ответственности начали задумываться еще в конце XIX - в начале XX вв. Многие американские политики и бизнесмены выражали уверенность в том, что предприятия обязаны всячески содействовать общественному благосостоянию. С самого начала частная и государственная благотворительность была широко распространенной формой оказания помощи нуждающимся. Например, сталепромышленник Эндрю 
Карнеги спонсировал строительство более чем 2 тысяч публичных библиотек, а Джон Рокфеллер создал благотворительный Фонд Рокфеллера. Но государственная благотворительность по своим масштабам и по объему финансовых затрат значительно превосходила частную. Частная благотворительность обеспечивала только четверть всей поддержки, предоставляемой нуждающимся, остальная помощь исходила от государственных (федеральных), штатных и муниципальных органов власти.

Однако в 30-е годы в США разразилась Великая депрессия, и руководители компаний перестали задумываться о какой бы то ни было социальной ответственности корпораций. Люди отнеслись к этому с пониманием, поскольку сами ждали от бизнеса только прибыли и наличия рабочих мест. Примерно в середине 50-х годов в США укрепилось сотрудничество между бизнесом и правительством, был создан комитет по экономическому развитию. В него вошли самые видные представители мира бизнеса с целью консультировать правительство по важным экономическим вопросам. Значение этого комитета возрастало, поскольку увеличивалась степень участия делового сообщества в решении проблем государственной и социальной политики.

Произошедшие в 1960-х гг. беспорядки в США побудили корпорации обратить еще больше внимания на вопросы социальной ответственности. Неблагоприятные условия жизни городской бедноты заставили крупнейшие корпорации вложить деньги и использовать человеческие ресурсы для улучшения ситуации, особенно в депрессивных регионах. Немного позднее (в начале 70-х гг.) уменьшение социальной ответственности бизнеса вызвало усиление негативного отношения общества к деловому миру. Корпорациям пришлось принять действенные меры в ответ на движения в защиту прав потребителей, их вклады в филантропические акции начали значительно увеличиваться. Новый этап активности последовал в 1980-е гг., когда дей- 
ствия администрации Р. Рейгана по сокращению федеральной помощи общественным программам послужили толчком к тому, что различные организации и частные лица стали осаждать корпорации с просьбами о финансовых средствах, предоставлении оборудования. Просьбы исходили не только от добровольных общественных организаций, но и от государственных учреждений, оказавшихся перед перспективой крупных сокращений своих бюджетов. А поворотным событием в понимании американскими предпринимателями принципов и форм КСО стало сокращение по инициативе Конгресса США в 1996 г. ассигнований некоммерческим организациям на период 1997-2002 гг. на 90 млрд долларов. Были свернуты или существенно урезаны программы социальной защиты, ограничены субсидии на строительство жилья, уменьшен доступ к бесплатной медицинской помощи. Правительство США обратилось к бизнес-сообществу с просьбой заполнить образовавшиеся пустоты, поскольку проблемы нищеты, наркомании, алкоголизма, бездомности, распространения СПИДа были такими же острыми, как и прежде. Американский бизнес откликнулся на этот призыв, так как в эпоху экономики знаний бесспорным является вывод о том, что инвестиции в школьное образование обеспечат достойную смену квалифицированных кадров, развитие физкультуры, спорта, искусства способствует повышению духовной составляющей жизненного уровня людей, а финансовые вливания в систему социального обеспечения поднимают конкурентоспособность США на мировом рынке.

Наиболее четко современное отношение американских компаний к КСО, социальным программам выразил профессор экономики Университета штата Огайо Ричард Стекель: «Для компаний, которые хотят заниматься лишь производством и сбытом своей продукции, социальная ответственность представляется трудновыполнимой задачей. Те из них, кто не справился с ней, проиграют в конкурентной борьбе. Те же компании, которые стремятся к ее решению через стратегическое партнерство с некоммерческими организациями, обретут 
мощный инструмент обеспечения рентабельности и жизнеспособности своего бизнеса на долгосрочную перспективу» [9]. Что же касается современного отношения американского правительства к вопросам КСО: «У правительства и бизнеса есть взаимные обязательства; ...совместное выполнение этих обязательств приносит пользу нам всем» (Президент США Барак Обама).

Государственный департамент США твердо придерживается принципов корпоративной социальной ответственности. Это подтверждается комплексным подходом к помощи и методической поддержке в областях ответственного корпоративного поведения. В соответствии с экономическим курсом, о котором объявил госсекретарь США и который нацелен на использование глобальных экономических инструментов для достижения целей Соединенных Штатов в сфере международной политики, отдельные бюро и офисы играют ведущую роль в определенных инициативах. В то же время они обеспечивают эффективную координацию и партнерство между собой, с посольствами США, коммерческими предприятиями, организациями гражданского общества и прочими заинтересованными сторонами. Существует тесная взаимосвязь между экономическим процветанием, соблюдением прав человека и добропорядочным корпоративным гражданством. Бюро по вопросам экономики и бизнеса предоставляет методическую и другую поддержку американским компаниям, реализующим социальные программы и соблюдающим этику ведения бизнеса, способствующую устойчивому развитию. Оно также работает с бизнесом, профсоюзами и гражданским обществом над принятием и внедрением образцовых корпоративных политик. В рамках этой работы взаимодействие с частным сектором во многом регламентируется рекомендациями для транснациональных корпораций, составленными Организацией по экономическому сотрудничеству и развитию (ОЭСР), а также национальными положениями, разработанными Бюро по вопросам экономики и бизнеса для адаптации этих рекомендаций к условиям США. Каждый год Госдепартамент вручает 
отличившимся на поприще социальной активности предприятиям премию госсекретаря за образцовую корпоративную деятельность.

Бюро по вопросам демократии, прав человека и трудовых отношений и его управления по вопросам международных трудовых отношений, свободе интернета, бизнеса и прав человека сотрудничают с компаниями, гражданским обществом (в том числе профсоюзами и неправительственными организациями) и правительствами, внедряя политики, способствующие соблюдению прав человека и трудовых прав, а также максимально увеличивающие положительное влияние на глобальное развитие. Управление по вопросам бизнеса и прав человека уделяет основное внимание привлечению заинтересованных сторон к решению конкретных проблем относительно сочетания бизнеса и прав человека. Кроме того, оно координирует усилия правительства США, направленные на внедрение Руководящих принципов ООН по вопросам бизнеса и прав человека. В частности, управление способствует стандартизации бизнеса и прав человека, демонстрирует пользу надежных систем, учитывающих интересы всех задействованных сторон, стимулирует компании соблюдать права человека и признанные на международном уровне трудовые права на всех этапах цепочек поставок, а также предлагает решения для злободневных политических проблем, препятствующих соблюдению прав человека корпорациями. А Управление по вопросам интеллектуальной собственности Бюро по вопросам экономики и бизнеса работает над защитой интеллектуальной собственности в целях обеспечения соблюдения прав человека. Краткое описание становления КСО в России и США приведено в таблице 4. 


\section{История становления КСО в России и США}

\begin{tabular}{|c|c|}
\hline Россия & США \\
\hline \multicolumn{2}{|c|}{ Конец XIX - начало XX вв. } \\
\hline $\begin{array}{l}\text { Меценатство со стороны крупных россий- } \\
\text { ских промышленников и купцов. } \\
\text { Примеры Е.В. Морозова по строительству } \\
\text { больниц, П.В. Третьякова в содействии куль- } \\
\text { турному развитию и многих других }\end{array}$ & $\begin{array}{l}\text { Помощь промышленников и предпри- } \\
\text { нимателей нуждающимся слоям насе- } \\
\text { ления, вклады в культуру и медицину. } \\
\text { Примеры благотворительных фондов } \\
\text { Карнеги и Рокфеллера }\end{array}$ \\
\hline \multicolumn{2}{|c|}{ 30-е гг. - конец 80-х гг. ХХ в. } \\
\hline $\begin{array}{l}\text { - плановая экономика; } \\
\text { - общая государственная социально-эконо- } \\
\text { мической программа повышения благососто- } \\
\text { яния советского народа; } \\
\text { - право граждан на социальное обеспечение } \\
\text { закреплено Конституцией СССР; } \\
\text { - фондами социального обеспечения явля- } \\
\text { ются бюджет государственного социального } \\
\text { страхования, дополнительные ассигнования } \\
\text { государства и отчисления колхозов }\end{array}$ & $\begin{array}{l}\text { - «Великая депрессия» 30х гг. - силь- } \\
\text { ный упадок бизнеса, и, соответ- } \\
\text { ственно, сокращение социальной от- } \\
\text { ветственности корпораций; } \\
\text { - 50-е гг. - тесное сотрудничество } \\
\text { между бизнесом и правительством } \\
\text { в решении социальных проблем; } \\
\text { - 60-е гг. - увеличение КСО, вызван- } \\
\text { ное беспорядками в обществе и движе- } \\
\text { ниями в защиту прав потребителей; } \\
\text { - 80-е гг. - новый всплеск КСО } \\
\text { в связи с сокращением помощи обще- } \\
\text { ственным программам правительства } \\
\text { Рейгана }\end{array}$ \\
\hline \multicolumn{2}{|c|}{ 90-е годы XX - начало XXI в. } \\
\hline $\begin{array}{l}\text { - 90-е гг. - нестабильность в стране; силь- } \\
\text { ное расслоение общества; несистемная част- } \\
\text { ная благотворительность; } \\
\text { - 2001-2006 гг. - рост активности КСО; } \\
\text { формирование современной трактовки КСО; } \\
\text { - } 2007 \text { г. - экономический кризис; резкое } \\
\text { снижение уровня КСО }\end{array}$ & $\begin{array}{l}\text { - } 1996 \text { г. - переломный момент - со- } \\
\text { кращение по инициативе Конгресса } \\
\text { США ассигнований некоммерческим } \\
\text { организациям на период 1997-2002 гг. } \\
\text { на } 90 \text { млрд долларов. Правительство } \\
\text { обращается к бизнесу за помощью } \\
\text { в осуществлении социальных про- } \\
\text { грамм }\end{array}$ \\
\hline \multicolumn{2}{|c|}{2008 г. - настоящее время } \\
\hline $\begin{array}{l}\text { - закрепление имеющихся сведений о КСО; } \\
\text { - переход к стратегическому планирова- } \\
\text { нию; } \\
\text { - рост «популярности» КСО. } \\
\text { «Государство должно выстраивать баланс } \\
\text { между развитием рыночных отношений, } \\
\text { с одной стороны, и вопросами социальной } \\
\text { справедливости, - с другой...». (Президент } \\
\text { России В.В. Путин) }\end{array}$ & $\begin{array}{l}\text { - укрепление и развитие системы } \\
\text { КСО. } \\
\text { «У правительства и бизнеса есть вза- } \\
\text { имные обязательства; ...совместное } \\
\text { выполнение этих обязательств прино- } \\
\text { сит пользу нам всем» (Президент } \\
\text { США Барак Обама) }\end{array}$ \\
\hline
\end{tabular}




\section{3. Нормативно-правовое регулирование корпоративной социальной ответственности организаций в Российской Федерации}

В российских условиях полноценное развитие корпоративной социальной ответственности приобретает стратегическое значение, в первую очередь - в рамках развития отношений и обучения своих работников, предоставления возможностей социального и карьерного роста для отдельных категорий персонала. Компании ежегодно декларируют существенный прирост финансовых вложений в социальную сферу в рамках публикуемой финансовой и нефинансовой (в том числе социальной) отчетности, расширение социального пакета для своих работников для обеспечения мотивации и повышения производительности труда, а также привлечения новых кадров. В данных условиях существует значимость в поиске и обосновании ключевых направлений социального инвестирования, проработка мероприятий социальной ответственности и учет потенциальных рисков. На уровне международных стандартов за последние годы имеет особое значение концепция устойчивого развития, в рамках которой осуществляется реализация различных проектов в экологической и социальной сфере, при этом данная деятельность может быть полноценно включена в стратегию предприятия. Несмотря на то, что деятельность предприятия в рамках КСО является в основном добровольной, существует четырехуровневая система нормативно-правового регулирования данной сферы, которую можно представить в виде схемы (рuс. 2) [26].
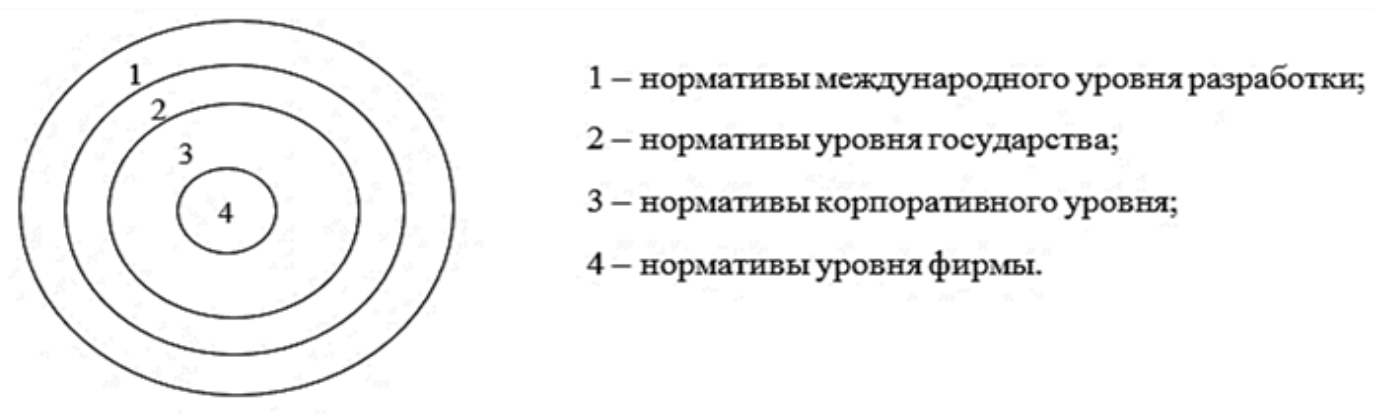

Рисунок 2. Нормативная среда регулирования корпоративной социальной ответственности 
Первый уровень системы - нормативы международного уровня разработки. Начиная с 1990-х годов на международном уроне начали создаваться организации по разработке рекомендаций в отношении корпоративного социального управления. Ряд таких рекомендаций зачастую носят общий характер, имеют базовые принципы и подходы, а также добровольны к принятию.

Ко второму уровню системы относят нормативы государственного уровня, на котором установленные политические, экономические и культурные особенности развития страны формируют отличающиеся друг от друга национальные модели корпоративной социальной ответственности.

Третьим уровнем системы нормативно-правового регулирования социальной ответственности являются нормативы на уровне корпорации. Корпоративный уровень предполагает соблюдение базовых принципов международного уровня, а также определенных требований, предъявляемых к компаниям в той или иной стране. Следование предприятием определенным нормативам по социальной ответственности может быть обязательным требованием для ее участия в той или иной отраслевой ассоциации.

К четвертому уровню системы относятся нормативы уровня экономического субъекта (фирмы). Нормативы внутрифирменного уровня регулирования корпоративной социальной ответственности формируют нормы, которые соответствуют документам международного, государственного и корпоративного уровней нормативного регулирования КСО.

О начавшихся процессах стандартизации определенного ряда международных документов, таких как AA1000, SA8000, Рекомендации GRI, под влиянием глобализации может свидетельствовать работа по их интеграции. 
При работе различных инициатив в области корпоративной социальной ответственности существует стремление к унификации, которое позволяет сформировать единые стандарты социального поведения организаций, общепринятые в мировом сообществе. На этом будет базироваться дальнейшее развитие нормативно-правового регулирования социальной ответственности за счет сопоставления различных показателей экономической и социальной эффективности на международном уроне. В таблице 5 приведена краткая характеристика наиболее распространенных нормативных документов международного уровня разработки в хронологическом порядке принятия.

Таблицуа 5

Краткая характеристика основных международных нормативных документов, регулирующих КСО [26]

\begin{tabular}{|c|c|c|c|}
\hline Норматив & $\begin{array}{c}\text { Год при- } \\
\text { нятия }\end{array}$ & Разработчик & Особенности \\
\hline $\begin{array}{l}\text { Документы меж- } \\
\text { дународной } \\
\text { организации } \\
\text { труда }\end{array}$ & - & $\begin{array}{l}\text { Международная } \\
\text { организация } \\
\text { труда }\end{array}$ & $\begin{array}{l}\text { Отражают общие базовые принципы } \\
\text { в области трудовых отношений }\end{array}$ \\
\hline ISO 14001 & 1996 & $\begin{array}{l}\text { Международная } \\
\text { организация } \\
\text { по стандартиза- } \\
\text { ции }\end{array}$ & $\begin{array}{l}\text { Касается системы менеджмента } \\
\text { организации в области охраны окру- } \\
\text { жающей среды }\end{array}$ \\
\hline ISO 14001 & 1996 & $\begin{array}{l}\text { Международная } \\
\text { организация } \\
\text { по стандартиза- } \\
\text { ции }\end{array}$ & $\begin{array}{l}\text { Касается системы менеджмента } \\
\text { организации в области охраны окру- } \\
\text { жающей среды }\end{array}$ \\
\hline $\begin{array}{l}\text { Social } \\
\text { Accountability } \\
8000 \text { (SA 8000) }\end{array}$ & 1997 & $\begin{array}{l}\text { Международная } \\
\text { организация } \\
\text { по социальной } \\
\text { отчетности }\end{array}$ & $\begin{array}{l}\text { Содержит показатели } \quad \text { и методику } \\
\text { аудита и сертификации фирмы по тру- } \\
\text { довым отношениям }\end{array}$ \\
\hline $\begin{array}{l}\text { Рекомендации } \\
\text { ОЭСР для ТНК }\end{array}$ & 2000 & $\begin{array}{l}\text { Организация } \\
\text { экономического } \\
\text { сотрудничества } \\
\text { и развития }\end{array}$ & $\begin{array}{l}\text { Является международным всеобъем- } \\
\text { лющим кодексом корпоративного по- } \\
\text { ведения }\end{array}$ \\
\hline
\end{tabular}


Окончание Таблищы 5

\begin{tabular}{|c|c|c|c|}
\hline $\begin{array}{l}\text { Глобальный до- } \\
\text { говор ООН }\end{array}$ & 2000 & $\mathrm{OOH}$ & $\begin{array}{l}\text { Охватывает универсальные принципы } \\
\text { по правам человека, труда, окружаю- } \\
\text { щей среды и борьбы с коррупцией }\end{array}$ \\
\hline $\begin{array}{l}\text { Руководство } \\
\text { по отчетности } \\
\text { устойчивого } \\
\text { развития }\end{array}$ & 2000 & $\begin{array}{l}\text { Глобальная } \\
\text { инициатива } \\
\text { по отчетности }\end{array}$ & $\begin{array}{l}\text { Предлагает методику составления от- } \\
\text { четности, включающую набор индика- } \\
\text { торов для комплексной оценки устой- } \\
\text { чивости развития фирмы с учетом эко- } \\
\text { номической, социальной и экологиче- } \\
\text { ской составляющих }\end{array}$ \\
\hline $\begin{array}{l}\text { Нормы ООН } \\
\text { относительно } \\
\text { обязанностей } \\
\text { компаний в обла- } \\
\text { сти прав человека }\end{array}$ & 2003 & $\mathrm{OOH}$ & $\begin{array}{l}\text { Сводный документ по правам человека } \\
\text { содержит ряд соответствующих требо- } \\
\text { ваний к фирме }\end{array}$ \\
\hline $\begin{array}{l}\text { Account Ability } \\
1000 \text { (AA1000) }\end{array}$ & 2003 & $\begin{array}{l}\text { Британский Ин- } \\
\text { ститут } \\
\text { социальной } \\
\text { и этической от- } \\
\text { четности }\end{array}$ & $\begin{array}{l}\text { Содержит серию базовых стандартов } \\
\text { по интегрированному управлению со- } \\
\text { циальными практиками фирмы. Нор- } \\
\text { матив устанавливает строгие требова- } \\
\text { ния к формированию социальной от- } \\
\text { четности, а также описывает основные } \\
\text { положения для ее верификации } \\
\text { и аудита }\end{array}$ \\
\hline
\end{tabular}

Нормативные документы международного уровня разработки зачастую содержат базовые подходы и принципы, добровольны к принятию и имеют общий характер. Так, Рекомендации Организации экономического сотрудничества и развития указывают направления транснациональным компаниям на формирование условий, которые были бы не менее благоприятными, чем установленные местными нормами. Такой нормативный документ, как Резолюция Совета Европейского союза по труду и социальной политике по корпоративной социальной ответственности, призывает организации распространять принципы корпоративной социальной политики и на дочерние подразделения.

Документы международного уровня создают рамочные, общие условия для нормативов последующих уровней, поскольку обладают 
не только преимуществами (в том числе формирование единых общемировых ценностей), но и недостатками (например, универсальность подходов, не учитывающих национальных особенностей).

В Российской Федерации содержание конкретных мероприятий, ориентированных на обеспечение права всех граждан на охрану здоровья и безопасности труда, связано с различными сферами ответственного поведения предприятия, среди которых особенно важны следующие:

- охрана окружающей природной среды.

Правовое регулирование в этой сфере осуществляется в соответствии с Федеральным законом от 10.01.2002 г. № 7-Ф3 «Об охране окружающей среды» [27];

- благоприятные и безопасные условия труда.

Согласно 37 статье Конституции РФ, каждый гражданин страны имеет право свободно распоряжаться своими способностями к труду, а также выбирать профессию и род деятельности [28]. Также Конституцией закреплено право каждого гражданина на труд в условиях, которые отвечают всем требованиям безопасности и гигиены, что получает развитие в трудовом законодательстве и в первую очередь в Трудовом кодексе РФ;

- благоприятные условия быта, обучения, воспитания и отдыха.

Данные условия устанавливаются работодателем на уровне локального нормативно-правового регулирования, в том числе они отражаются в коллективном договоре, а также в рамках индивидуального регулирования трудовых отношений. В содержании трудового договора, в частности, могут предусматриваться дополнительные требования об улучшении социально-бытовых условий сотрудника и членов его семьи (ст. 57 Трудового кодекса РФ) [29];

- оказание качественной и доступной медицинской помощи. 
Конкретное содержание мероприятий, относящихся к обеспечению оказания качественной и доступной медицинской помощи, определено в статье 10 Федерального закона от 21.11.2011 г. № 323-Ф3 «Об основах охраны здоровья граждан в Российской Федерации» [30].

Права граждан на охрану здоровья также обеспечиваются юридической ответственностью со стороны должностных лиц за сокрытие ими обстоятельств и фактов, создающих угрозу для здоровья и жизни людей (ч. 3 ст. 41 Конституции РФ), что соответствует праву каждого на доступность информации о состоянии окружающей среды и возмещение ущерба, причиненного здоровью или имуществу экологическим правонарушением [28].

Исходя из рассмотренных мероприятий, реализуемых в рамках корпоративной социальной ответственности, можно сделать вывод о том, что правовое обеспечение КСО в Российской Федерации базируется на комплексном использовании всей системы юридических норм, которые регулируют различные сферы общества. Исходя из этого, можно сказать, что необходимость в создании специального законодательного акта по корпоративной социальной ответственности отсутствует. В качестве аргументов можно назвать следующие факторы:

- отечественная нормативно-правовая база на сегодняшний день содержит порядка 175 тысяч актов в области корпоративной социальной ответственности, однако многие из них на практике не применяются. В связи с этим существует риск: новый специализированный закон в этой области может также стать невостребованным, как и другие, а также не сможет оказать существенного влияния на ее совершенствование и развитие;

- анализ применения Ф3 «Об основах охраны здоровья граждан в Российской Федерации» показал, что большинство вопросов корпоративной социальной ответственности уже урегулированы в различ- 
ных нормативных актах общественных отношений (социальное обеспечение, трудовое законодательство, экологические, налоговые и иные отношения). В связи с этим нецелесообразна переработка значительного объема действующих законов с целью вычленения из них вопросов корпоративной социальной ответственности в отдельный специализированный нормативно-правовой акт;

- анализ правового регулирования социальной ответственности на международном уровне также указывает на то, что в значительной части зарубежных стран специального законодательства о КСО не существует, при этом вопросы по ее регулированию остаются в рамках общественных, а не правовых отношений и соответствуют принятым международным стандартам.

\section{4. Методические подходы к анализу и оценке эффективности корпоративной социальной ответственности предприятий}

В научной экономической литературе оценка корпоративной социальной ответственности рассматривается по-разному, исходя из различных теоретических методов и подходов, применяемых для сбора и анализа данных.

Под методами оценки КСО понимается совокупность действий по оценке состояния практики в сфере социально ответственной деятельности фирмы. При этом в процессе оценки и анализа КСО учитываются специфические особенности организации, такие как размер компании; стадия ее жизненного цикла; отраслевая принадлежность фирмы, организационно-правовая форма, публичный или непубличный характер организации и пр.

Результаты оценки эффективности КСО дают возможность организации определить сильные и слабые стороны в данной области и обосновать направления деятельности по ее совершенствованию. 
Иначе говоря, методы оценки эффективности корпоративной социальной ответственности являются важными инструментами для принятия управленческих решений.

В настоящее время разработано и применяется множество различных методических подходов к оценке эффективности корпоративной социальной ответственности предприятий. Однако предпринимаются последующие попытки поиска новых подходов и методов, позволяющих оценивать эффективность КСО фирмы в рамках принятых систем оценок и развития уже существующих. При оценке эффективности КСО предприятия часто применяются следующие показатели: относительные, абсолютные величины, средние и индексные системы.

Еще в 1984 году Ф.Л. Кочран и Р.А. Вуд в своей работе «Корпоративная социальная ответственность и финансовый результат» предлагают два метода оценки КСО [31]. Один из них - репутационный индекс, который заключается в том, что компетентные наблюдатели (эксперты, которые проводят оценку) составляют рейтинг компаний на основе одного или нескольких измерителей социального результата. Второй метод, предложенный Ф.Л. Кочраном и Р.А. Вудом, контент-анализ, который позволяет измерить степень отчетности в различных публикациях, в частности в годовых отчетах. Данный метод допускает использование как качественного, так и количественного анализа данных. При этом сами авторы отмечают, что у двух данных методов есть как достоинства, так и недостатки.

А. Калабрезе, Ф. Розати, Р. Коста в качестве базы для оценки действий по раскрытию отчетности по КСО определили руководство по отчетам в области устойчивого развития глобальной инициативы отчетов (GRI), исходя из того, что данное руководство является наиболее полным и структурированным для раскрытия данных отчетов [32].

В ходе проведения анализа более 50 методических подходов к оценке эффективности социальной ответственности организаций 
Никитина Л.М. и Борзаков Д.В. классифицируют все методики следующим образом [33]:

- по уровню создания (мега, макро, мезо и микро), включая активное развитие региональных инициатив в данной сфере;

- по позиции разработанной концепции, которая положена в основу оценки эффективности социальной ответственности корпорации (устойчивое развитие, уровень социальных инвестиций, социальный потенциал и др.);

- по направлению оценки КСО (внешняя оценка, самооценка или смешенная);

- по содержанию оценки (системы, методики отчетности, рейтинговые, индексные, индикативные и конкурсные методики).

Методические подходы к анализу эффективности КСО с точки зрения оценки социального инвестирования представлены в работах Н.А. Кричевского, К.А. Руденко, В.Б. Вязового, В.А. Бахметьева и др.

Методический подход Н.А. Кричевского и С.Ф. Гончарова включает в себя качественные и количественные показатели КСО [34]. Авторы предлагают объединить качественные показатели в три группы:

- показатели корпоративной социальной ответственности перед персоналом;

- показатели КСО предприятия перед обществом, включая расходы на социальную поддержку окружающего сообщества;

- показатели КСО по экологическим аспектам.

Количественные показатели оценки эффективности социальной активности компании не всегда могут в полной мере отразить характер социальной направленности бизнеса. Исходя из этого, С.Ф. Гон- 
чаров и Н.А. Кричевский предлагают использование системы качественных показателей для оценки эффективности КСО. Тем не менее недостатком данного метода может являться поверхностная оценка качественного уровня социальной активности, которая не показывает степень проявления критериев в деятельности фирмы.

Также Г.Л. Тульчинским предложен комплексный методический подход к оценке эффективности КСО, который позволит комплексно оценить социальную активность фирмы, сравнивать предприятия вне зависимости от вида их деятельности, организационноправовой формы и ведомственной принадлежности [35, с. 68-74]. Данная методика базируется на таких показателях, которые характерны для любого предприятия. Анализ предполагает поэтапное сравнение. Методика состоит из 5 этапов:

- выделение основных направлений развития КСО;

- выделение показателей по каждому из направлений;

- определение значений в баллах с расчетом весовых коэффициентов;

- анализ динамики показателей в процентах;

- определение фактического значения итоговой суммы баллов.

Данный подход предполагает определение уровня корпоративной социальной ответственности и формирование рейтингов как по отдельным направлениям КСО, так и в совокупности. Достоинством методики является возможность объективного сравнения предприятий независимо от их специализации, сектора экономики и прочих параметров.

Многофакторная модель, разработанная Н.Ю. Псаревой, позволяет оценить уровень развития КСО и ее соответствие требованиям международных и национальных стандартов в данной области [36]. Модель предполагает оценку развития социальной ответственности 
по шкале от 1 до 5 (где 1 - очень низкий, 5 - очень высокий уровень). Оценка проводится по следующим группам факторов проявления социальной активности:

- социальная политика организации;

- эффективность и результативность;

- окружающая среда;

- взаимоотношения со стейкхолдерами.

Однако данная методика не содержит набора конкретных показателей, рекомендаций по самооценке и работе с экспертами.

Помимо вышеупомянутых методик в настоящее время в международной практике анализа и оценки эффективности КСО существует набор индексов и рейтинговых инструментов, получивших широкое распространение. Такие инструменты можно разделить на две группы: фондовые и нефондовые индексы корпоративной социальной ответственности [37].

Фондовые индексы учитывают социальные, финансовые, этические, экологические аспекты: KLD, SAM, EIRIS, Dow Jones Sustainability Index (DJSI), FTSE4Good Index и др.

Нефондовые индексы применяются в основном для сравнительного позиционирования на базе социальных аспектов деятельности предприятия: CPI (Corporate Philanthropy Index), SI (Social Index).

Кроме существующих методик по оценке количественных и качественных показателей, индексных и рейтинговых инструментов, есть и другая группа методик, которая учитывает взаимоотношения с группами заинтересованных сторон предприятия. К примеру, российское рейтинговое агентство «Репутация» (далее - РА «Репутация») использует методику социальной ответственности, которая состоит из следующих элементов [38]: 
- взаимодействие с потребителями и заказчиками;

- права персонала;

- взаимодействие с обществом;

- экология и охрана окружающей природной среды;

- экономическая результативность предприятия.

По итогам оценки уровня КСО предприятия используется рейтинговая шкала «Российская национальная шкала», созданная РА «Репутация», которая учитывает совокупный набор показателей, характерных для большинства предприятий. Данная шкала разделена на шесть классов рейтинга корпоративной социальной ответственности (рис. 3).

Индекс «S» характеризует рейтинговую оценку, присвоенную в отношении КСО исследуемой компании.

Несмотря на доступность данного метода, он также имеет недостаток, которым является то, что из большого количества заинтересованных сторон чаще всего рассматривают только две группы из вышеперечисленных: взаимодействие с потребителями и заказчиками и взаимодействие с обществом. Оценивая уровень КСО, целесообразно также принимать во внимание отношения и с другими внешними и внутренними стейкхолдерами, например, с такими как персонал, акционеры, профсоюзы, контрагенты, потенциальные инвесторы, конкуренты и т.д.

Необходимо отметить, что для глубокого анализа социальной активности предприятия необходимо качественную и индексную оценку его социальной ответственности дополнять количественной. Исходя из этого, использование системы оценки, базирующейся на количественных показателях КСО организаций, весьма целесообразно. 


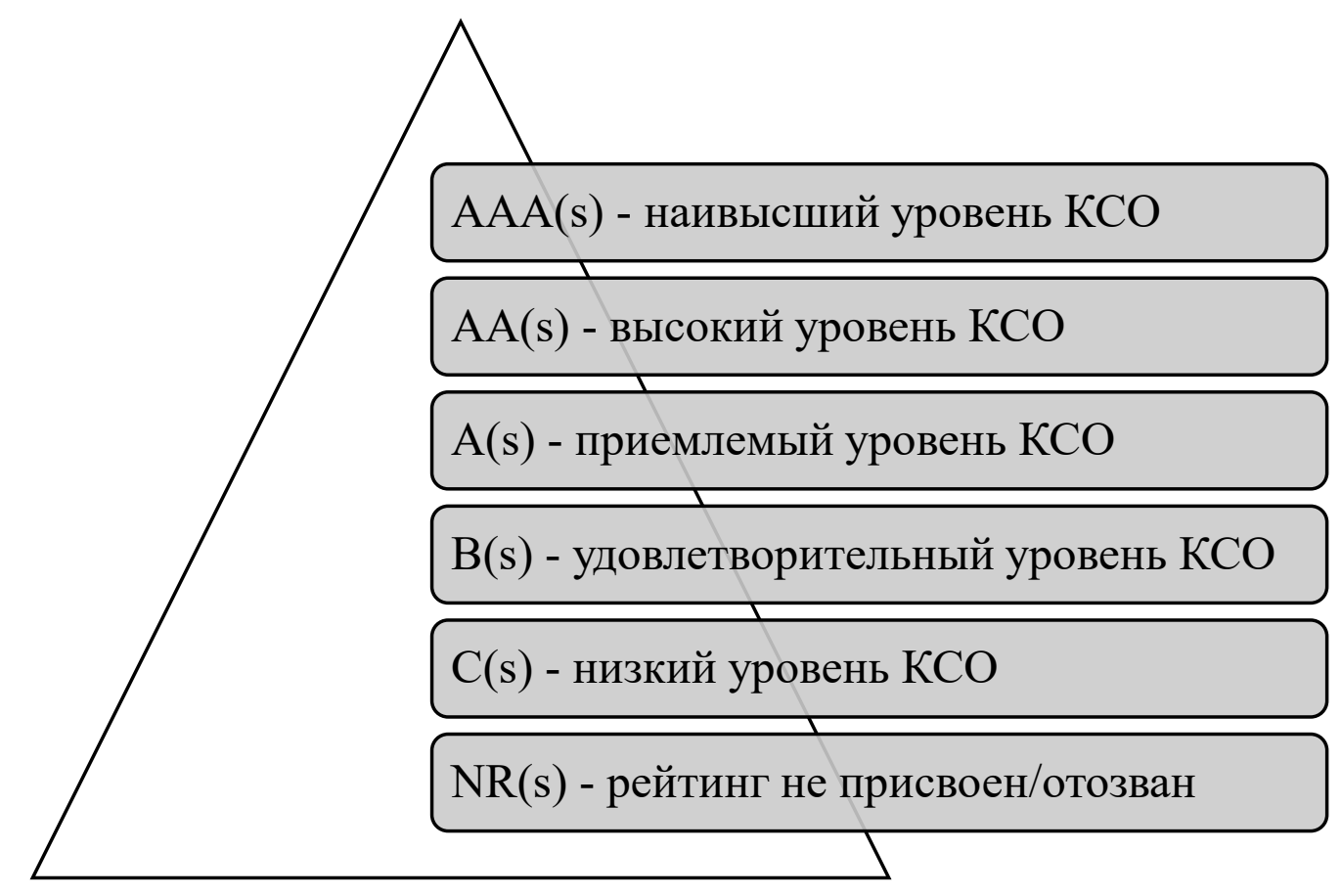

Рисунок 3. Российская национальная шкала оценки уровня социальной ответственности организации РА «Репутация»

Для количественной оценки индекса социального инвестирования Ассоциацией менеджеров России выделено три вида индексов социальных инвестиций российских компаний [39]:

- доля социальных инвестиций исследуемых организаций к общему объему их прибылей (до налогообложения), в процентах:

$$
I P=\frac{\sum_{i=1}^{n} C_{i}}{\sum_{i=1}^{n} P_{i}}
$$

где $C_{i}$ - объем социальных инвестиций і-й фирмы (в том числе обязательные и добровольные затраты на социальные программы); $P_{i}$ - общий объем прибыли всех исследуемых компаний (до налогообложения); 
- индекс удельных социальных инвестиций, который представляет собой объем социальных инвестиций организаций, приходящийся на одного работника, в рублях:

$$
I L=\frac{\sum_{i=1}^{n} C_{i}}{\sum_{i=1}^{n} L_{i}}
$$

где $L_{i}$ - среднесписочная численность работников і-й организации; n - количество исследуемых компаний;

- доля социальных инвестиций исследуемых организаций к общему объему их продаж, в процентах:

$$
I S=\frac{\sum_{i=1}^{n} C_{i}}{\sum_{i=1}^{n} S_{i}} \cdot 100 \%
$$

где $S_{i}$ - валовой объем продаж і-го предприятия.

При этом существуют некие трудности при такой оценке корпоративной социальной ответственности:

- определение и оценивание социальной ориентированности предприятия по сумме социальных инвестиций, вложенных в КСО, не совсем корректно. Поскольку в большинстве случаев наибольший объем инвестиций на восстановление окружающей среды приходится на те предприятия, которые сами явились причиной ее загрязнения;

- отсутствие необходимости в отчетной информации. Это объясняется тем, что предлагаемые методические подходы, как правило, базируются на показателях, которые отражены в публикуемых отчетах далеко не всех организаций. Исходя из этого, расчет количествен- 
ной оценки эффективности корпоративной социальной ответственности становится возможным не для всех организаций. Исходя из этого, для устранения в существующих методических подходах к количественной оценке эффективности КСО недостатков необходимо соблюдать два принципа:

- избегать оценки сумм, которые направляются на социальные программы предприятиями;

- использовать для анализа уровня корпоративной социальной ответственности наиболее распространенные показатели публикуемой отчетности финансово-хозяйственной деятельности предприятий. В связи с этим влияние экономических показателей организации, которые отражают его конкурентоспособность, желательно рассматривать во взаимосвязи с показателями КСО.

Показатель социальной направленности предприятия перед окружением (то есть вклад в развитие местного сообщества) наиболее важен для предприятий градообразующего комплекса и определяется по формуле (4) [40, с. 16]:

$$
k_{\text {cou.oкp. }}=\frac{k_{H}+k_{p . n .}+k_{c . u .}}{3}
$$

где $k_{н}$ - доля налогов, уплаченных организацией в пользу региональных и местных бюджетов;

$k_{p . n .}$ - доля местных компаний-партнеров;

$k_{c . u .}$ - доля добровольных инвестиций организации в суммарной величине инвестиций, полученных органами местной власти или региона за период. 
Данные параметры следует рассчитывать в соотношении размера вклада компании по отношению к суммарному региональному или местному показателю.

При этом каждый коэффициент рассчитывается по следующим формулам:

$$
k_{H}=\frac{H_{n p}}{\sum H_{p e z}}
$$

где $H_{n p}$ - размер налогов, которые перечисляются организацией в региональные (местные) бюджеты;

$H_{\text {рег }}$ - размер налогов, которые поступают в региональный (местный) бюджет.

$$
k_{p . n .}=\frac{\Psi_{p . n .}}{\Psi_{p e r . n .}}
$$

где $\Psi_{p . n .}-$ число местных партнеров (поставщики и клиенты) предприятия;

$\Psi_{\text {pez.n. }}$ - число предприятий в регионе.

$$
k_{c . u .}=\frac{C h_{n p .}}{C h_{p .}}
$$

где $C h_{n p}$ - размер добровольных социальных инвестиций в развитие территории осуществления деятельности предприятия (региона);

$C И_{p .}$ - общий размер запланированных инвестиций социальной направленности местным бюджетом. 
Показатель $k_{c . u .}$ - один из наиболее существенных в определении социальной направленности предприятия. Он позволяет судить о значимости организации (в том числе градообразующего предприятия) со стороны приоритетов местного сообщества, например [41, c. $152-154]$ :

- развитие и поддержание социальной сферы места расположения предприятия (региона);

- участие в инвестиционных проектах;

- обеспечение занятости населения.

Осуществление такой деятельности значительно снижает или вовсе снимает социальную напряженность между частью социально активного населения, занятого на градообразующем предприятии, и той частью населения, работающего на других местных предприятиях и в сфере услуг.

Рассмотренные методические подходы к оценке эффективности КСО организации базируются на системных принципах, которые, в свою очередь, отвечают всем условиям устойчивого развития - социальной направленности деятельности, экономической стабильности и экологической безопасности, а также могут отвечать современной изменчивости российской экономики.

Однако, несмотря на универсальность представленных методических подходов, практическая социальная деятельность предприятий требует формирования надежного инструментария для рационального обоснования социальных вложений. Также, проводя контент-анализ литературы, выяснилось, что на данный момент на практике не существует единого методического подхода к экономической оценке эффективности корпоративной социальной ответственности предприятий монопрофильных городов. Исходя из этого, рассмотренные методики послужат базой для дальнейшего исследования в рамках изучения и формирования авторского инструментария развития 
корпоративной социальной ответственности промышленных предприятий в моногородах и последующего инвестирования в КСО.

Таким образом, доказано, что актуальной задачей является разработка инструментария развития корпоративной социальной ответственности промышленных предприятий в моногородах. В соответствии с этим вытекает значение дальнейшего научно-практического исследования данного вопроса для подтверждения значимости корпоративной социальной ответственности предприятий монопрофильных городов. В частности, необходимо проведение анализа уровня развития КСО промышленных предприятий моногородов Российской Федерации, а также анализа их населения и отраслевой специализации градообразующих предприятий. Для анализа уровня развития КСО промышленных предприятий в моногородах предлагается проанализировать раскрытие информации о практиках социальной ответственности и социальных вложений градообразующих предприятий по следующим параметрам:

- управление персоналом и внутренние социальные программы;

- взаимодействие с местным сообществом и благотворительность;

- экономическая результативность и профиль компании;

- экология и природоохранные мероприятия;

- стратегии, системы управления и политика;

- права человека;

- система коммуникаций и взаимодействие со стейкхолдерами;

- управление качеством;

- другие темы. 
В рамках проведения анализа также требуется изучение показателей КСО градообразующих предприятий, относящихся к внутренней социальной среде, раскрываемых в нефинансовой отчетности, таких как:

- общая численность персонала;

- количество сотрудников, прошедших обучение;

- количество сотрудников, получивших обучение на внутрикорпоративной учебной базе;

- количество сотрудников, получивших повышение разряда или повышение в должности после прохождения обучения;

- затраты на обучение сотрудников.

Для более полного исследования также необходимо оценить социальные аспекты внутри моногородов, такие как:

- динамика численности населения моногородов за последние 10 лет;

- уровень заболеваемости населения монопрофильных городов, в том числе структура профзаболеваний внутри градообразующих предприятий.

Проведение данного анализа позволит определить существующий уровень развития КСО предприятий российских моногородов, а также выявить их недостатки для разработки авторского инструментария развития корпоративной социальной ответственности промышленных предприятий в моногородах и оценки экономической эффективности его применения. 


\section{2. АНАЛИЗ УРОВНЯ РАЗВИТИЯ КОРПОРАТИВНОЙ СОЦИАЛЬНОЙ ОТВЕТСТВЕННОСТИ ПРОМЫШЛЕННЫХ ПРЕДПРИЯТИЙ МОНОГОРОДОВ РОССИЙСКОЙ ФЕДЕРАЦИИ}

\section{1. Особенности корпоративной социальной ответственности промышленных предприятий в моногородах}

Термин «моногород» в России появился сравнительно недавно, в конце XX века. В законодательных актах РФ также можно встретить термины «монопромышленный город», «город с монопрофильной структурой хозяйства» и «город с монопроизводственной структурой». В научной и экономической литературе также используются понятия «монопрофильный город» и «монофункциональный город».

Моногород - муниципальное образование, в котором большая часть экономически активного населения работает на основном предприятии этого города, которое часто называют градообразующим предприятием или предприятием градообразующего комплекса [42, с. 62].

В Российской Федерации предприятиями градообразующего комплекса признаются организации, численность работников которых составляет не менее $25 \%$ численности работающего населения соответствующего населенного пункта [43].

В настоящее время Распоряжением РФ от 29.07.2014 № 1398-р (ред. от 13.05.2016) «Об утверждении перечня монопрофильных муниципальных образований РФ (моногородов)» утвержден список монопрофильных городов Российской Федерации, который включает в себя 319 муниципальных образований [44].

Монопрофильные города в России разделены на три категории, которые определяются в зависимости от степени ухудшения социально-экономической ситуации в них: 
- монопрофильные муниципальные образования Российской Федерации (моногорода) с наиболее сложным социально-экономическим состоянием (в том числе во взаимосвязи с проблемами функционирования градообразующих предприятий) (100 моногородов);

- моногорода Российской Федерации, в которых имеются возможные риски ухудшения социально-экономического положения (148 моногорода);

- монопрофильные муниципальные образования Российской Федерации (моногорода) с относительно стабильным социально-экономическим положением (71 моногород).

Муниципальные органы власти по отношению к развитию монопрофильных городов формируют различные системы услуг (привлекая для этого бизнес), повышают долю перерабатывающих производств, финансируют объекты социальной инфраструктуры, развивают для этого малый и средний бизнес, определяют ключевые сферы социального и экономического развития.

В этой области муниципальные органы власти осуществляют следующие направления деятельности:

- формирование системы гарантий для инвестиционной работы;

- определение четких процедур и правил для открытия новых организаций разных форм собственности;

- ведение объективной ценовой политики на товары и услуги;

- установление понятных правил землепользования, отвода земельных участков под строительство;

- решение вопросов по установлению налоговых льгот;

- разработка и осуществление программы повышения привлекательности (имиджа) моногорода; 
- формирование банка данных, раскрывающих инновационный и инвестиционный потенциал;

- осуществление информационной поддержки различных проектов и т.П.

Корпоративная социальная ответственность бизнеса по отношению к моногородам должна учитывать существующий мировой термин imprinting, который подразумевает феномен территориального закрепления любого живого существа (в том числе и человека) за конкретным местом, где он родился и провел детство. Импринтинг в особенности характерен для жителей малых городов, в том числе монопрофильных, поскольку крупные города по большей мере равнодушны к прошлому человека, малым формам и структурам обеспечения его жизни.

Отличительной чертой современной ситуации в России является то, что ответственность за социальные условия жизни населения монопрофильных городов лежит на государственных и муниципальных органах власти лишь формально, когда на самом деле фактически эта ответственность лежит на градообразующих предприятиях этих моногородов. При этом муниципальные и государственные органы власти не всегда имеют достаточные ресурсы для реализации этой ответственности. В то время как предприятия, которые имеют необходимые ресурсы, недостаточно мотивированы для реализации мероприятий КСО, поскольку это противоречит неоклассическим взглядам на конечные цели фирмы.

Бизнес-структуры в лице самих градообразующих предприятий в первую очередь должны определять источники инвестиций, искать пути повышения инновационной активности, обосновывать возможности реструктуризации организации и решать проблемы для внедрения новых технологий. 
Также в связи с последствиями любых возможных негативных ситуаций в стране, которые могут вызвать ухудшение финансово-экономических показателей градообразующих предприятий, возможна опасность остановки или закрытия производств и массового сокращения персонала. Все это негативно сказывается на уровне социальноэкономического развития моногородов. Исходя из этого, необходимо понимать значимость совершенствования управления инвестиционными ресурсами в рамках осуществления корпоративной социальной ответственности предприятиями моногородов.

Эффективность корпоративной социальной ответственности градообразующего предприятия не всегда напрямую выражается в денежной форме. Тем не менее рациональное и эффективное направление инвестиционных потоков на реализацию мероприятий КСО дает ряд закономерных последствий, которые в конечном итоге будут являться благом для всего моногорода и для самого градообразующего предприятия (рост инвестиционной привлекательности, укрепление имиджа и репутации компании, повышение качества управления бизнесом).

Для оценки эффективности корпоративной социальной ответственности предприятия моногорода необходимо рассматривать не только внутренние показатели экономической эффективности деятельности организации, но и внешние показатели со стороны самого города (например, через систему здравоохранения, образования, спорта, а также с помощью рассмотрения динамики численности населения города и других показателей).

На территории Свердловской области насчитывается 17 моногородов [44]. В качестве примера рассмотрим показатели двух монопрофильных муниципальных образований Свердловской области, реализующих мероприятия по корпоративной социальной ответственности: 
- Верхнесалдинский городской округ, который относится к категории моногородов со стабильной социально-экономической ситуацией. Градообразующим предприятием моногорода является ПАО «Корпорация ВСМПО-АВИСМА»;

- городской округ Верхняя Пышма, относящийся к категории моногородов, в которых имеются риски ухудшения социально-экономического положения. Градообразующим предприятием моногорода является АО «Уралэлектромедь».

Структура населения Верхнесалдинского городского округа по его отношению к трудовой деятельности градообразующего предприятия и иных организаций за 2017-2018 гг. представлена на рисунке 4.

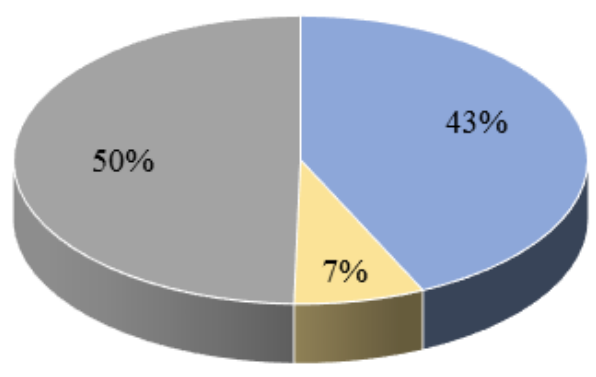

2017 год

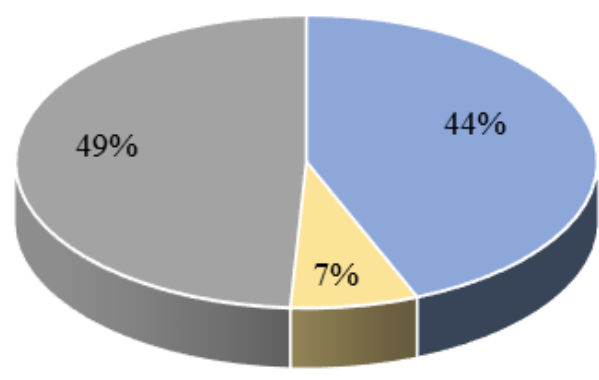

2018 год

" ССЧ работников ПАО "ВСМПО-АВИСМА"

ССЧ работников других организаций

- Экономически неактивное население

Рисунок 4. Структура занятости населения Верхнесалдинского городского округа $[45,46,47]$

Структура населения городского округа Верхняя Пышма по его отношению к трудовой деятельности градообразующего предприятия и иных организаций за 2017-2018 гг. представлена на рисунке 5. 


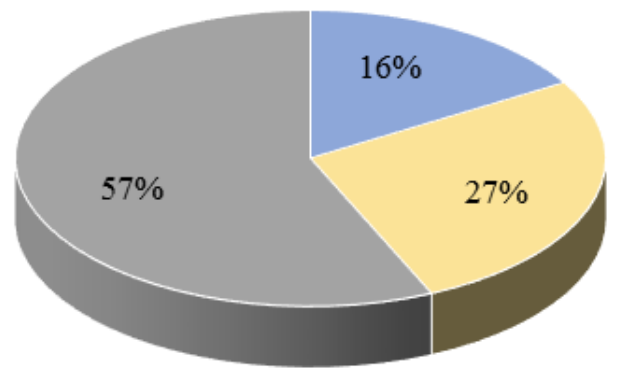

2017 год

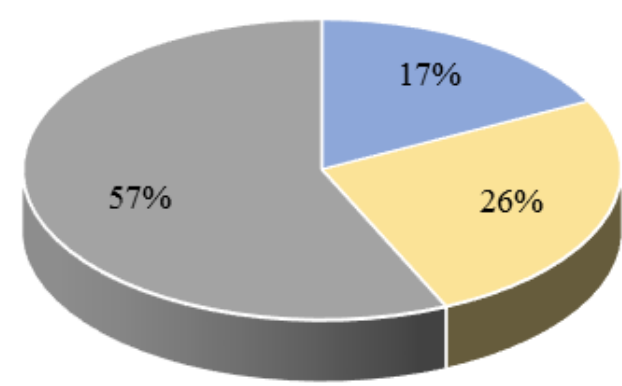

2018 год

$$
\begin{aligned}
& \text { " ССЧ работников АО "Уралэлектромедь" } \\
& \text { " ССЧ работников других организаций } \\
& \text { " Экономически неактивное население }
\end{aligned}
$$

Рисунок 5. Структура занятости населения городского округа Верхняя Пышма [47, 48, 49]

Как видно из представленных диаграмм, численность всего населения двух монопрофильных городов Свердловской области различается, при этом среднесписочная численность (далее - ССЧ) работников градообразующего предприятия Верхнесалдинского городского округа значительно больше ССЧ работников городского округа Верхняя Пышма.

По данным на 2018 год, численность работников градообразующего предприятия ПАО «Корпорация ВСМПО-АВИСМА» составила $86,1 \%$ от всего занятого населения Верхнесалдинского городского округа. Притом как численность работников градообразующего предприятия АО «Уралэлектромедь» составила лишь 29,7\% от всего занятого населения городского округа Верхняя Пышма.

Также рассмотрим динамику затрат на реализацию мероприятий КСО градообразующих предприятий Верхнесалдинского городского округа и городского округа Верхняя Пышма за 2016-2018гг. (рис. 6). 


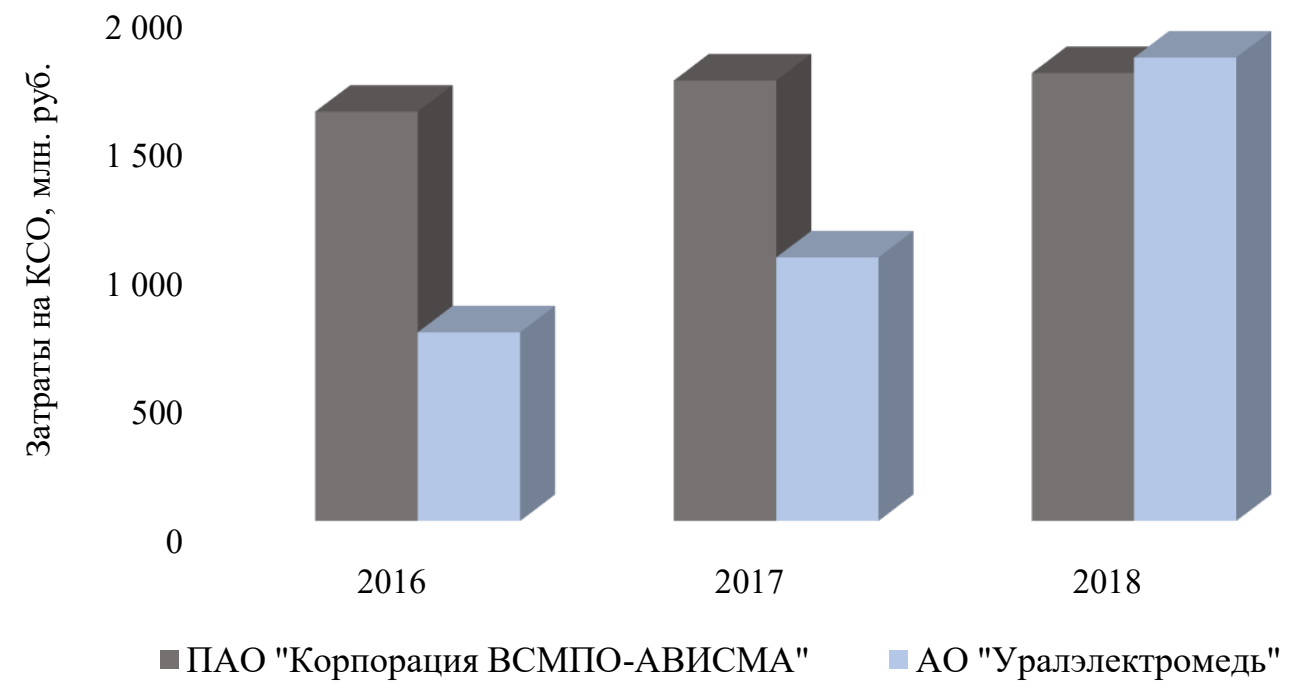

Рисунок 6. Динамика затрат градообразующих предприятий на КСО, млн руб. (на основе публичной отчетности) [46, 49]

Из представленного графика можно сделать вывод, что объем средств, направленных на выполнение социальных обязательств за 2016-2018 гг. ПАО «Корпорация ВСМПО-АВИСМА», значительно не изменился и имеет тенденцию роста и на конец 2018 года составил 1740 млн руб. В то время как расходы на социальные и благотворительные цели АО «Уралэлектромедь» увеличились значительно и на конец 2018 года по сравнению с предыдущим годом возросли на $75,8 \%$.

Сопоставив данные по рисункам 4, 5 и 6, следует, что несмотря на то, что ССЧ работников градообразующего предприятия моногорода с большей численностью населения значительно меньше ССЧ работников градообразующего комплекса моногорода с меньшей численностью населения, вложения в социальную ответственность этих предприятий увеличиваются и стали практически равными. 
Таким образом, рассматривая взаимосвязь категории, к которой относится моногород, численности занятого населения на градообразующем предприятии и вложений в КСО этого предприятия, можно сделать вывод, что необходимо анализировать также и другие экономические и социальные показатели для более полного представления и принятия последующих решений в рамках корпоративной социальной ответственности.

\section{2. Российские моногорода: социально-экономическое положение, население и отраслевая специализация предприятий}

Социально ответственное поведение для градообразующих предприятий является достаточно естественным и в некоторой степени обязательным явлением. С момента возникновения таких предприятий они были в определенной мере вынуждены принимать участие в поддержании и развитии благополучия населенного пункта, в котором они функционируют. Так, усилиями градообразующих предприятий происходило совершенствование социальной сферы и городской инфраструктуры, строительство жилых домов, обеспеченность дополнительным медицинским обслуживанием и проведение иной социальной поддержки. Общественные, образовательные, спортивные, культурные и медицинские организации моногородов по факту напрямую зависели от спонсорской поддержки таких организаций.

Периодически происходящие в последние годы кризисные явления приводят к тому, что градообразующим предприятиям приходится сокращать свои расходы по многим статьям. В том числе это касается и направлений социальной активности: в лучшем случае расходы стали более рациональными и планируемыми. В частности, некоторые предприятия сформировали фонды, занимающиеся распре- 
делением средств по реализации социальных проектов на конкурсных условиях. Так, наблюдается тенденция к приоритизации крупных проектов, притом что ранее компании могли тратить существенные суммы на реализацию любых текущих проектов.

Также необходимо учитывать, что возникновение моногородов не случайность. Значительное количество моногородов резко возросло в советское время. В малой степени возникновение монопрофильных городов происходило при индустриализации. Причина этого заключается в том, что производства либо реконструировались, либо они формировались сразу как комплекс предприятий с одним или несколькими головными подразделениями (например, Новокузнецк, Воркута и другие). Большинство монопрофильных городов основались за счет эвакуированных предприятий в военное время, а ряд организаций стали градообразующими.

Возникновение и существование моногородов также значительно связано с их территориальным расположением. Поскольку крупное горнодобывающие предприятие может находиться именно там, где располагается месторождение. В стране с огромной территорией и с огромными запасами полезных ископаемых это предприятие может находиться только там, где данные запасы есть. Это становится автоматическим условием возникновения условий для создания моногорода.

За последние 30 лет создано достаточно мало действительно крупных предприятий. Помимо этого ряд руководителей предприятий рассуждают, что нет необходимости поддерживать моногород в связи с тем, что есть возможность возить работников на месторождения вахтовым методом. Но далеко не для всех градообразующих предприятий это возможно. Существует ряд производств со сложным циклом переработки, например горно-обогатительные комбинаты. 
В Европе данная проблема ощущается меньше, поскольку площади значительно меньше, и трудовая миграция, таким образом, незаметна. В европейских странах вокруг предприятия такого масштаба располагаются города-миллионники. Также там существуют запреты на большие перевозки продуктов питания, поэтому это создает условия и для инфраструктуры, и для занятости этого крупного населенного пункта. При этом в России, когда месторождение находится на большом расстоянии (более 500 км) от металлургического или перерабатывающего завода, становится очень трудоемко транспортировать такой материальный поток, чтобы его обработать.

Поэтому существование моногородов - это, безусловно, неизбежный факт в условиях любой большой территории, как Российская Федерация (также, например, Канада или Китай, в котором наблюдается дефицит рабочей силы на промышленных предприятиях).

Россия - индустриальная, промышленная страна, которая имеет огромное количество больших металлургических заводов. Для примера, на предприятиях Свердловской области АО «НПК «Уралвагонзавод» (г. Нижний Тагил) и ПАО «Корпорация ВСМПО-АВИСМА» (Верхнесалдинский городской округ) сосредоточен значительный потенциал, что намного целесообразнее и экономически выгоднее развивать эти моногорода и работать там, чем совершать попытки перемещения данных предприятий.

Таким образом, если существование моногородов - это неизбежность в Российской Федерации, обладающей огромными территориями и полезными ископаемыми, значит, с этим необходимо что-то делать. В том числе это требует и серьезного изменения законодательства, и необходимости понимания горизонта жизненного цикла предприятия моногорода, сколько оно сможет просуществовать и чем оно будет обладать.

Аналитический доклад Института комплексных стратегических исследований «Обзор российских моногородов», который основан 
на статистических данных Росстата, разделяет монопрофильные города на три категории [50]:

- «красная зона» - с наиболее сложным социально-экономическим положением (включает в себя 94 моногорода);

- «желтая зона» - с рисками ухудшения социально-экономического положения (154 моногорода);

- «зеленая зона» - со стабильной социально-экономической ситуацией (71 моногород).

На рисунке 7 представлено распределение численности населения монопрофильных городов России по категориям социально-экономической ситуации моногородов («зеленая», «желтая» и «красная» зоны).

Исходя из представленного графика, можно сделать вывод о том, что большая часть монопрофильных городов находятся в пограничной или критической ситуации, при этом дальнейшие перспективы для таких городов остаются вполне неопределенными.

В Российской Федерации в 61 из 85 регионов имеются монопрофильные муниципальные образования, которые в основном сосредоточены в регионах Поволжья и Сибири. На данных территориях находится большая часть российских моногородов (66 моногородов в СФО, 79 - в ПФО), население которых составляет 55\% от всего населения федеральных округов.

В Российской Федерации в 61 из 85 регионов имеются монопрофильные муниципальные образования, которые в основном сосредоточены в регионах Поволжья и Сибири. На данных территориях находится большая часть российских моногородов (66 моногородов в СФО, 79 - в ПФО), население которых составляет 55\% от всего населения федеральных округов. 


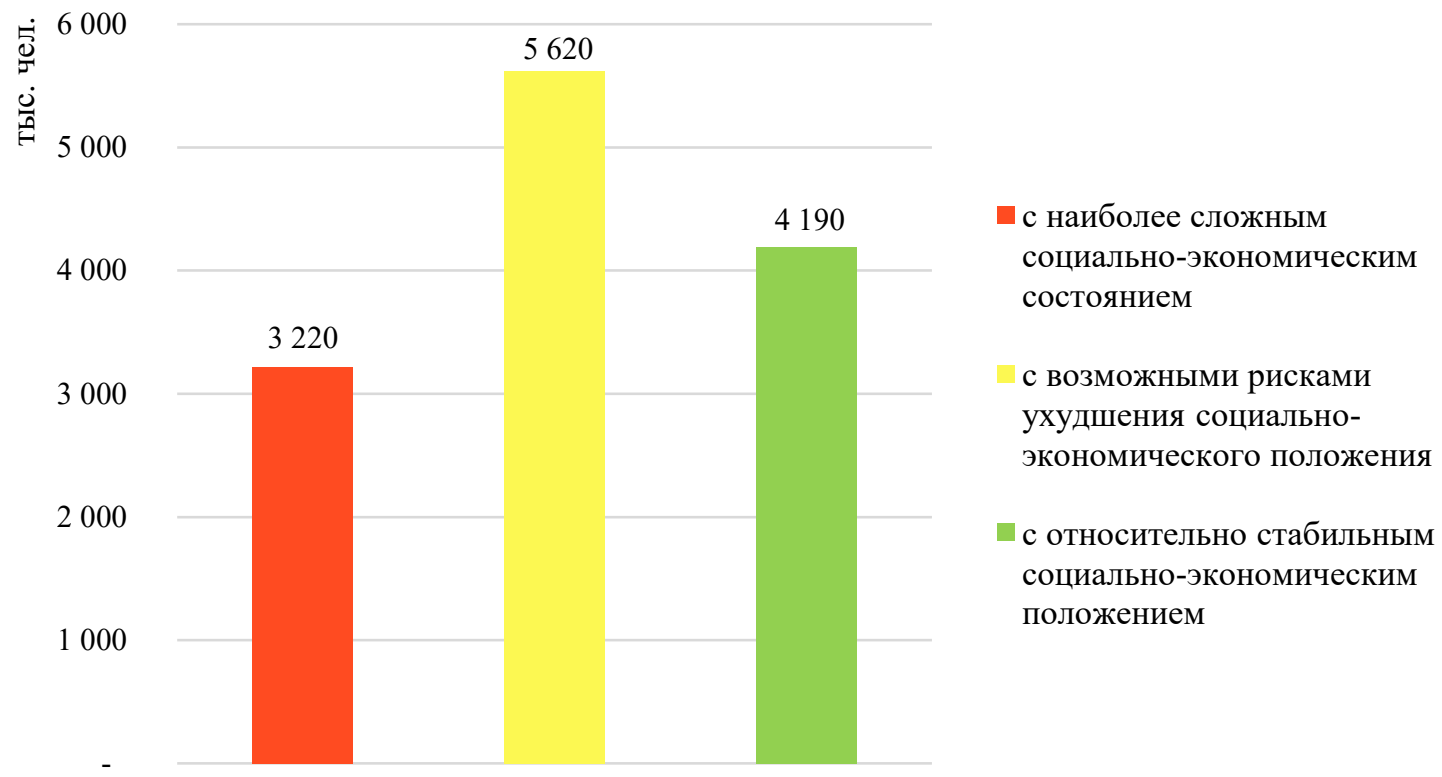

Рисунок 7. Распределение населения российских моногородов по категориям социально-экономического положения (по состоянию на декабрь 2018 года), тыс. чел.

В регионах ПФО в моногородах проживает 14\% населения, а в регионах СФО - 16\%, притом что в среднем по стране этот показатель составляет около 9\% населения.

К тому же значительное количество моногородов с нестабильной социально-экономической ситуацией, относящихся к «желтой» и «красной» зонам, приходится именно на эти территории регионов (рис. 8). 


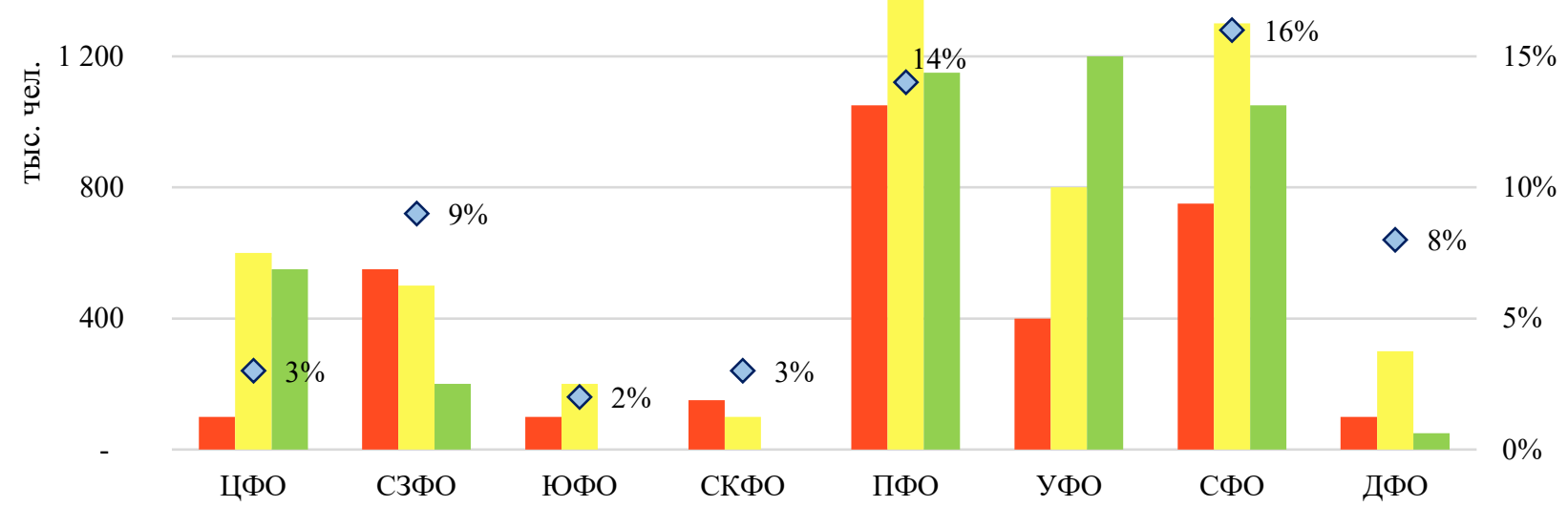

п с наиболее сложным социально-экономическим положением

с рисками ухудшения социально-экономического положения

со стабильным социально-экономическим положением

$\diamond$ доля населения, проживающая в моногородах (правая шкала)

Рисунок 8. Численность населения моногородов по различным категориям по федеральным округам РФ (тыс. чел.) и доля населения округа, проживающего в монопрофильных городах (\%), по состоянию на 2018 год

Также в Центральном и Уральском федеральных округах размещено достаточно много моногородов. В ЦФО насчитывается 61 моногород, однако при этом данные поселения зачастую имеют небольшую численность населения.

При этом в таких моногородах достаточно разнообразна отраслевая специализация: от деревообработки, пищевой и текстильной промышленности до металлургии, атомной промышленности и др.

Помимо этого, самыми крупными в стране по численности населения являются моногорода УФО (это обусловлено в большей мере 
их отраслевой специализацией - машиностроение, металлургия, оборонная промышленность). 65,6 тысяч человек - численность жителей уральских моногородов в среднем. А в 6 моногородах округа численность населения превышает 100 тысяч. При этом насчитывается только 37 моногородов на территории УФО, однако на них приходится $20 \%$ населения всего округа.

Порядка 10 субъектов Российской Федерации имеют особое значение по ситуации с состоянием и развитием монопрофильных городов, поскольку доля населения, проживающего в моногородах, в этих регионах превышает 20\% (когда средний показатель по стране около 9\%) (табл. 6). В Кемеровской области наблюдается рекордный показатель - 60,3\% населения региона, при этом на территории области расположено всего 24 моногорода (основная отраслевая специализация городов - добыча угля).

Третья часть этих моногородов находится в наиболее сложном социально-экономическом положении, то есть относится к «красной» зоне (это города со специализацией в черной металлургии и производстве горно-шахтного оборудования, а также угледобывающие города, включая Прокопьевск, Анжеро-Судженск и другие).

Также необходимо отметить, что в этих регионах есть достаточно выраженная специализация моногородов. Так, большая часть монопрофильных городов Свердловской и Челябинской областей имеет специализацию в металлургии (черной и цветной), при этом Республика Карелия имеет специализацию в целлюлозно-бумажной и лесозаготовительной промышленности. Значительное количество монопрофильных городов из вышеупомянутых регионов относится к «красной» зоне, то есть с наиболее сложным социально-экономическим положением (более половины - в Челябинской области и в Карелии, а также около 30\% - в Свердловской области). Однако наряду 
с этим определенная часть монопрофильных городов в данных областях относятся к «зеленой» зоне и имеют относительно стабильное социально-экономическое положение.

Таблиияа 6

Сведения о субъектах Российской Федерации, имеющих более $20 \%$ населения, проживающего в моногородах (по состоянию на 2018 год)

\begin{tabular}{|c|c|c|c|c|c|c|}
\hline \multirow[b]{2}{*}{ Регион } & \multirow{2}{*}{$\begin{array}{c}\text { Доля насе- } \\
\text { ления } \\
\text { в моного- } \\
\text { родах, \% }\end{array}$} & \multirow{2}{*}{$\begin{array}{c}\text { Население } \\
\text { моногоро- } \\
\text { дов, тыс. } \\
\text { чел. }\end{array}$} & \multicolumn{4}{|c|}{$\begin{array}{c}\text { Количество моногородов, в том } \\
\text { числе }\end{array}$} \\
\hline & & & $\begin{array}{c}\text { «зеле- } \\
\text { ная } \\
\text { зона» }\end{array}$ & $\begin{array}{c}\text { «жел- } \\
\text { тая } \\
\text { зона» }\end{array}$ & $\begin{array}{c}\text { «крас- } \\
\text { ная } \\
\text { зона» }\end{array}$ & $\begin{array}{c}\text { всег } \\
\text { о }\end{array}$ \\
\hline $\begin{array}{l}\text { Кемеровская об- } \\
\text { ласть }\end{array}$ & 60,2 & 1636 & 4 & 12 & 8 & 24 \\
\hline $\begin{array}{l}\text { Челябинская об- } \\
\text { ласть }\end{array}$ & 32,3 & 1130 & 4 & 5 & 7 & 16 \\
\hline $\begin{array}{l}\text { Вологодская об- } \\
\text { ласть }\end{array}$ & 30,7 & 365 & 0 & 1 & 3 & 4 \\
\hline $\begin{array}{l}\text { Республика } \mathrm{Xa-} \\
\text { касия }\end{array}$ & 29,2 & 157 & 0 & 5 & 1 & 6 \\
\hline $\begin{array}{l}\text { Свердловская } \\
\text { область }\end{array}$ & 28,9 & 1253 & 6 & 6 & 5 & 17 \\
\hline $\begin{array}{l}\text { Республика Та- } \\
\text { тарстан }\end{array}$ & 26,7 & 1034 & 1 & 4 & 2 & 7 \\
\hline $\begin{array}{l}\text { Архангельская } \\
\text { область }\end{array}$ & 25,3 & 298 & 2 & 3 & 2 & 7 \\
\hline $\begin{array}{l}\text { Самарская об- } \\
\text { ласть }\end{array}$ & 24,5 & 786 & 1 & 1 & 0 & 2 \\
\hline $\begin{array}{l}\text { Республика Ка- } \\
\text { релия }\end{array}$ & 22,7 & 143 & 0 & 5 & 6 & 11 \\
\hline $\begin{array}{l}\text { Амурская об- } \\
\text { ласть }\end{array}$ & 21,4 & 173 & 0 & 2 & 2 & 4 \\
\hline
\end{tabular}

Примечательно, что в числе регионов моногорода с более благополучной ситуацией имеют специализацию, отличную от «основной» 
специализации монопрофильных городов этого региона. Так, большинство моногородов со стабильным положением в Свердловской и Кемеровской областях специализируются на черной и цветной металлургии, в Челябинской области - в атомной промышленности.

Значительная часть монопрофильных городов (около 26,3\% из 319 моногородов РФ), согласно расчетам Института комплексных стратегических исследований, специализируются в сфере металлургии, в том числе черной и цветной металлургии, добычи и обработки металлических руд, а также в производстве редких металлов [50]. При этом 18,5\% моногородов специализируются в машиностроительной промышленности - производство оборудования, транспортных средств и др.

В основном моногорода с машиностроительной и металлургической специализацией имеют около 60\% населения от всех монопрофильных муниципальных образований. В таблице 7 представлено распределение количества моногородов и их населения по специализациям градообразующих предприятий за 2018 год.

Также на рисунке 9 изображена структура моногородов с различным социально-экономическим положением по специализациям градообразующих предприятий.

Из представленного рисунка видно, что число моногородов со стабильным социально-экономическим положением - в основном с градообразующими предприятиями в отраслях пищевой, оборонной и атомной промышленностях. Значительное количество моногородов с наиболее сложной социально-экономической ситуацией имеют отраслевую специализацию в секторе деревообработки, текстильной и оборонной промышленности. 


\section{Распределение количества моногородов и их населения} по специализации градообразующих предприятий за 2018 год

\begin{tabular}{|l|c|c|c|c|}
\hline \multicolumn{1}{|c|}{ Отрасль } & $\begin{array}{c}\text { Количество } \\
\text { моногоро- } \\
\text { дов }\end{array}$ & $\begin{array}{c}\text { Доля в об- } \\
\text { щем количе- } \\
\text { стве, \% }\end{array}$ & $\begin{array}{c}\text { Численность } \\
\text { населения, млн } \\
\text { чел. }\end{array}$ & $\begin{array}{c}\text { Доля в об- } \\
\text { щей числен- } \\
\text { ности, \% }\end{array}$ \\
\hline Металлургия & 84 & 26,30 & 3,95 & 30,30 \\
\hline $\begin{array}{l}\text { Деревообра- } \\
\text { ботка }\end{array}$ & 38 & 11,90 & 0,64 & 4,90 \\
\hline $\begin{array}{l}\text { Машинострое- } \\
\text { ние }\end{array}$ & 59 & 18,50 & 3,81 & 29,30 \\
\hline $\begin{array}{l}\text { Угольная про- } \\
\text { мышленность }\end{array}$ & 30 & 9,40 & 1,34 & 10,30 \\
\hline $\begin{array}{l}\text { Производство } \\
\text { неметалличе- } \\
\text { ских продук- } \\
\text { тов }\end{array}$ & 37 & 11,60 & 0,68 & 5,20 \\
\hline $\begin{array}{l}\text { Химическая } \\
\text { промышлен- } \\
\text { ность }\end{array}$ & 23 & 7,20 & 1,16 & 8,90 \\
\hline $\begin{array}{l}\text { Пищевая про- } \\
\text { мышленность }\end{array}$ & 17 & 5,30 & 0,21 & 1,60 \\
\hline $\begin{array}{l}\text { Текстильная } \\
\text { промышлен- } \\
\text { ность }\end{array}$ & 12 & 3,80 & 0,19 & 1,50 \\
\hline $\begin{array}{l}\text { Оборонная } \\
\text { промышлен- } \\
\text { ность }\end{array}$ & 8 & 2,50 & 0,47 & 3,60 \\
\hline $\begin{array}{l}\text { Атомная про- } \\
\text { мышленность }\end{array}$ & 7 & 2,20 & 0,42 & 1,00 \\
\hline Транспорт & 4 & 1,30 & 0,14 & 13,03 \\
\hline Всего
\end{tabular}




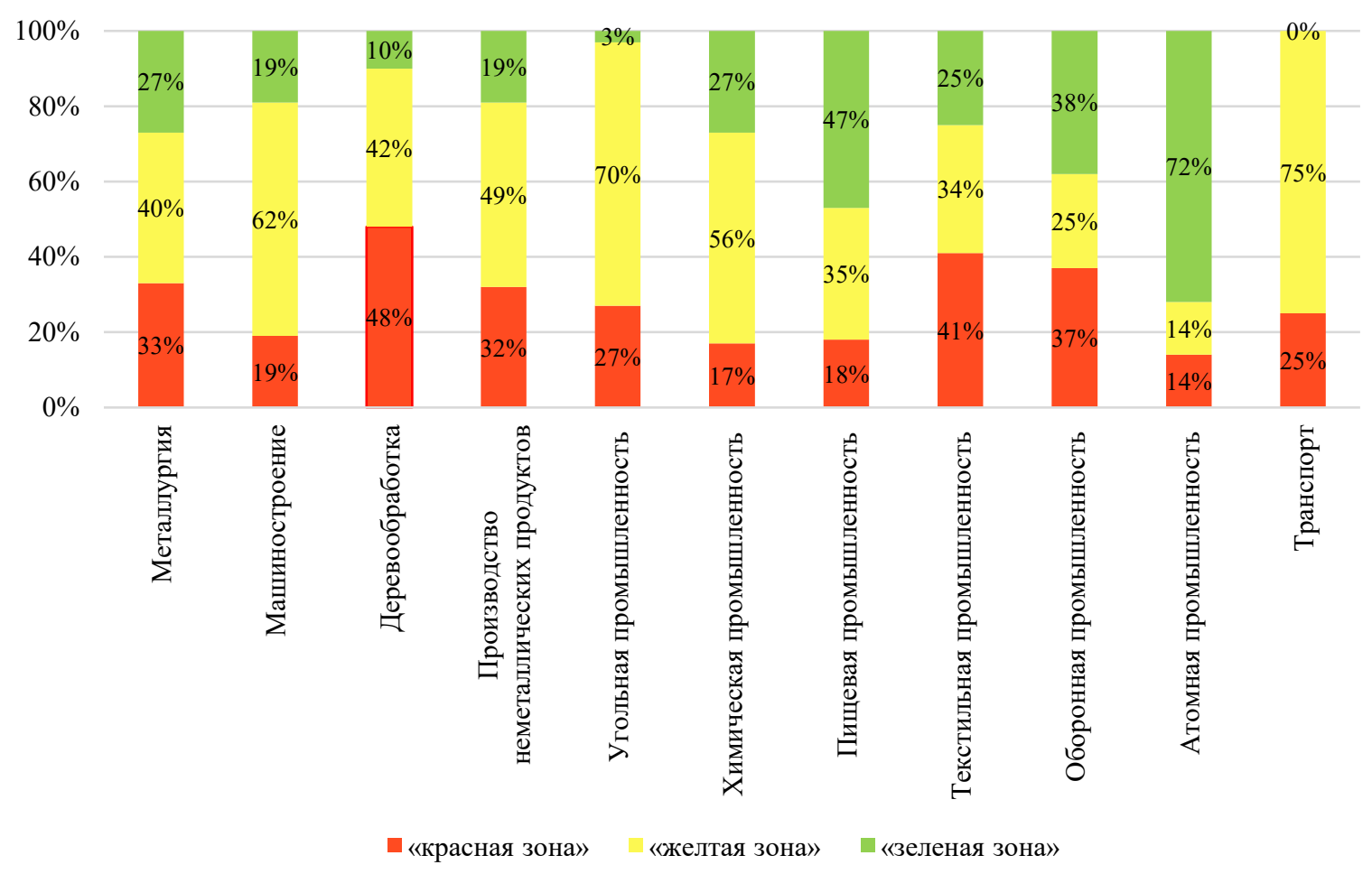

Рисунок 9. Структура моногородов по различным категориям и специализациям градообразующих предприятий за 2018 год, \%

Таким образом, доказано, что моногорода в большей степени зависят от деятельности градообразующих предприятий, которые осуществляют свою деятельность на их территории. Понятие «градообразующее предприятие» изначально употреблялось в отношении заводов старопромышленного пояса, которые обеспечивали не только экономическое развитие моногорода, но и его инфраструктуру. Осуществление мероприятий градообразующими предприятиями в данном направлении является основой корпоративной социальной ответственности, которая необходима для выживания подобных монопрофильных муниципальных образований. 


\section{3. Анализ уровня развития корпоративной социальной ответственности промышленных градообразующих предприятий России}

Понятие корпоративной социальной ответственности в российской практике ведения бизнеса не является новым: различные ведомства, крупные градообразующие предприятия еще в советское время принимали участие в развитии социальной сферы и поддерживали соответствующую инфраструктуру. Работники получали путевки в санатории, дома отдыха и лечебные заведения при предприятиях, также имели продолжительные оплачиваемые отпуска. Деятельность такого рода не рассматривалась руководителями предприятий как часть бизнес-стратегии их организаций, направленной на повышение эффективности, устойчивости и значимости предприятия. На данном этапе Россия активно интегрируется в мировое сообщество, и понимание корпоративной социальной ответственности бизнеса также приближается к мировым стандартам.

Проанализировав в первой главе монографии первоначальные источники научных взглядов на корпоративную социальную ответственность, можно сделать вывод, что в России, а значит, и в Свердловской области, нельзя рассматривать КСО как до конца развитое явление. Многие исследователи утверждают о частичном отсутствии КСО, поскольку существование такой ответственности базируется на конкретных потребностях общества и бизнеса, которые слишком далеки от западных.

Чтобы убедиться или опровергнуть подобные заявления, проанализируем предприятия монопрофильных городов Российской Федерации в отношении КСО, в частности градообразующие предприятия Свердловской области. В Екатеринбурге и Свердловской области на 1 октября 2019 года, по данным Управления Федеральной службы государственной статистики по Свердловской и Курганской области, 
осуществляют деятельность 116624 организации, находящиеся в частной собственности [51].

Рассмотрим особенности и характер информации о практиках вложений в социальную ответственность российских компаний, раскрываемой в социальной отчетности, которая относится к различным периодам деятельности и к разным группам стейкхолдеров. Также проанализируем и обобщим наблюдаемые тенденции на предмет раскрытия социально значимой информации. Среди крупнейших промышленных предприятий металлургического и горнодобывающего сектора моногородов РФ, раскрывающих отчетность, социальная деятельность которых будет проанализирована далее, являются ПАО «Магнитогорский металлургический комбинат» (г. Магнитогорск), ПАО «Северсталь» (г. Череповец), АК «АЛРОСА» (г. Мирный), ПАО «Корпорация «ВСМПО-АВИСМА» (г. Верхняя Салда).

Многие из исследуемых компаний для управления и сокращения рисков в области КСО публикуют нефинансовую отчетность. Это позволяет определять основные направления социальной деятельности при возникновении различных социальных проблем. Помимо этого, значимая часть компаний содействуют развитию регионов присутствия, а также формированию местных и региональных бюджетов за счет налоговых поступлений, тем самым обеспечивая дополнительную нагрузку в рамках КСО.

В Национальный Регистр нефинансовых отчетов по состоянию на апрель 2019 года занесено 176 организаций и зарегистрировано 924 отчета, публикуемых в период с 2000 года. В число таких нефинансовых отчетов входят [52]:

- социальные отчеты (326 отчетов);

- отчеты в области устойчивого развития (314 отчетов);

- интегрированные отчеты (176 отчетов);

- экологические отчеты (81 отчет); 
- отраслевые отчеты (27 отчетов).

На рисунке 10 представлен анализ общего уровня активности компаний ключевых отраслей промышленности в области формирования нефинансовой отчетности.

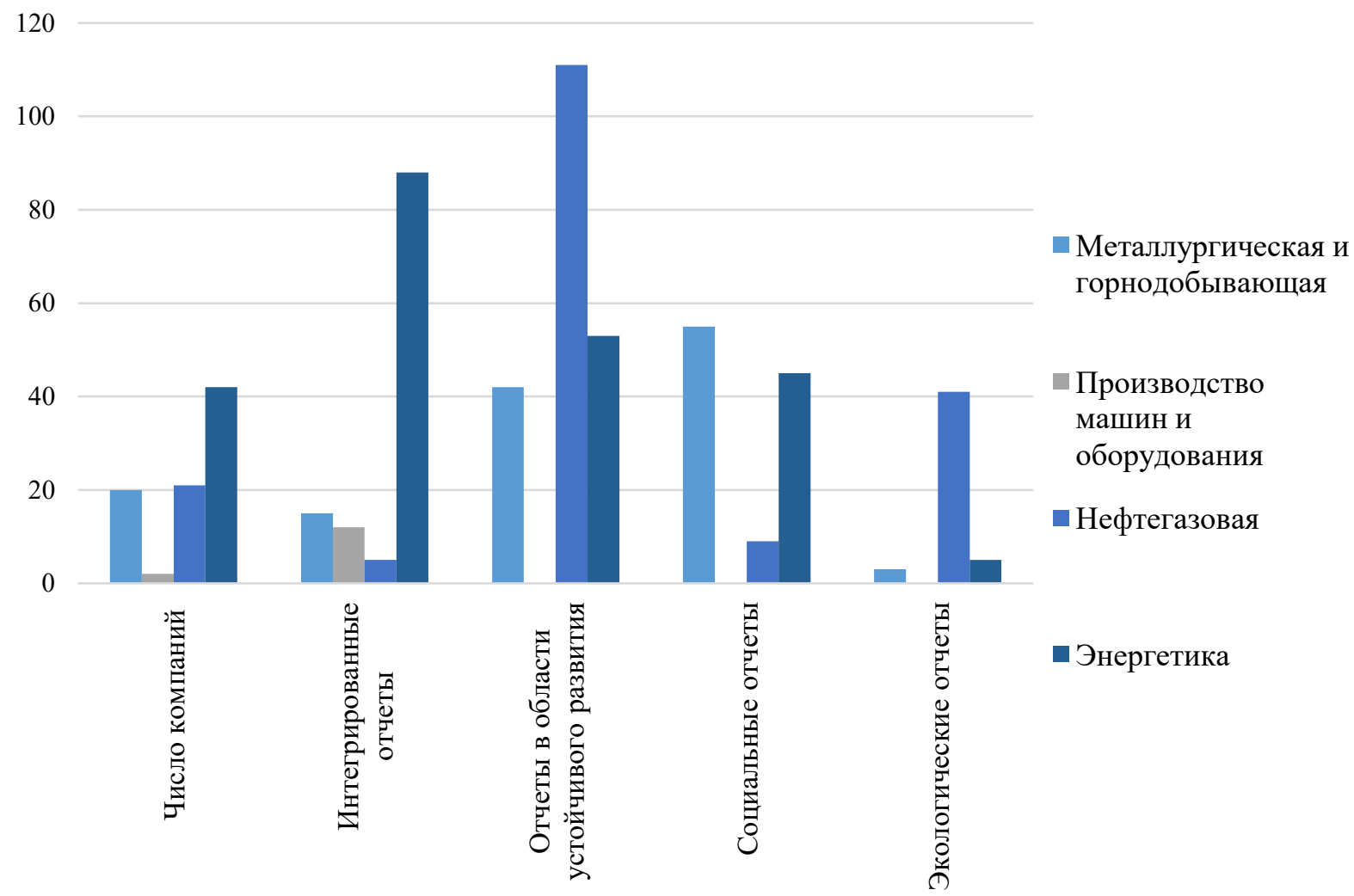

Рисунок 10. Показатели общего уровня активности компаний ключевых секторов экономики в области формирования нефинансовой отчетности по видам, в штуках по состоянию на апрель 2019 года [52]

Анализ нефинансовых отчетов в РФ показывает, что в формировании практики социальных вложений наибольший вклад закреплен за предприятиями металлургической, энергетической и нефтегазовой отраслей. Значительная часть нефтегазовых предприятий формируют и публикуют отчетность об устойчивом развитии, освещая социальную, экологическую и финансовую детальность организации, а также 
их влияние на стратегии устойчивого развития. Необходимо отметить, что значимую роль для металлургических компаний играет формирование социальной отчетности. При этом для нефтегазовых предприятий важно оценить вклад в развитие экологии территории присутствия, а также формирование адекватной оценки степени влияния основной деятельности компаний на окружающую среду. Предприятия по производству машин и оборудования вносят наименьший вклад в уровень активности формирования нефинансовой отчетности среди всех рассмотренных компаний.

Далее рассмотрим направления социальных вложений и раскрытия информации о социальной ответственности в нефинансовой отчетности российских компаний, раскрывающих такую информацию (puc. 11).

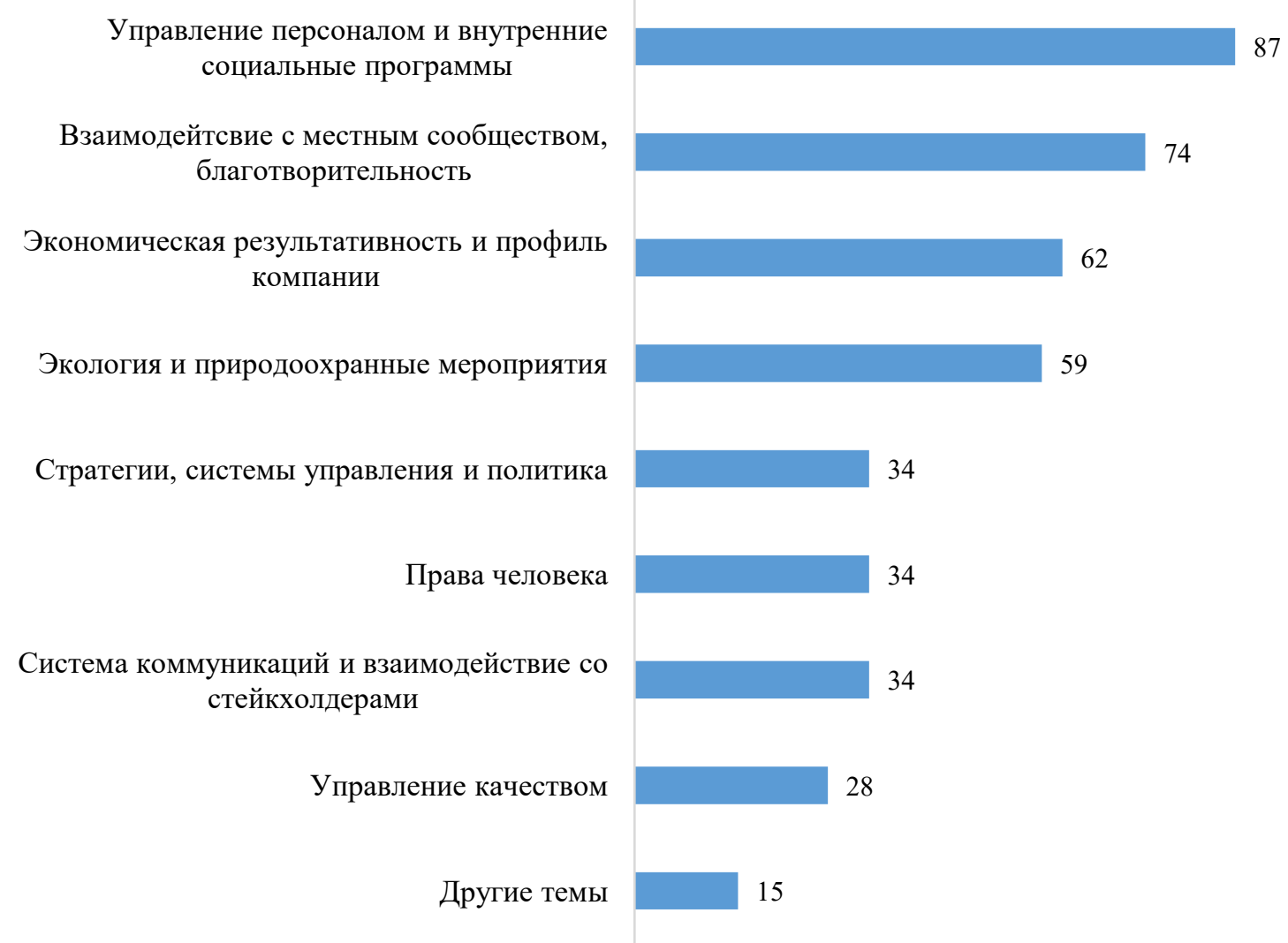

Рисунок 11. Раскрытие информации (по частоте включения в отчетность) о практиках социальной ответственности и социальных вложений на 2018 год, из анализа отчетов компаний, в процентах [52] 
Наиболее часто компании раскрывают в своей нефинансовой отчетности проблемы управления персоналом (около 90\% всех отчетов), данная информация содержится практически во всех нефинансовых отчетах, в частности - в социальных. Для значительной части компаний приоритетными темами также являются спонсорство и благотворительность. Большинство из них ежегодно реализуют спонсорские и благотворительные проекты. Наименьшее внимание предприятий, как правило, уделено системам взаимодействия со стейкхолдерами.

Для большинства российских предприятий практики по определению заинтересованных сторон (стейкхолдеров) и созданию неких стратегий по взаимодействию с ними являются новым опытом. Некоторые из таких компаний работают с уже созданной и устоявшейся целевой аудиторией, а для некоторых - идентификация стейкхолдеров остается неизведанной. Если речь идет о сотрудниках, то они являются стейкхолдерами по коллективным переговорам в трудовой сфере, на инвесторов предназначены многочисленные регулярные акционерные и иные собрания, а с общественностью работают PRслужбы [53, с. 97]. Несмотря на это, данные элементы коммуникации стейкхолдерами должны иметь системный характер, который закрепляется в социальной политике компаний. Публикуемая нефинансовая отчетность предприятий направлена на все заинтересованные стороны или по меньшей мере должна быть нацелена на раскрытие социальной политики и стратегии удовлетворения интересов большинства стейкхолдеров. Каждой социально ориентированной организацией самостоятельно определяются наиболее социально значимые направления и мероприятия по развитию для каждой из заинтересованных сторон. Так, в разные годы для промышленных градообразующих предприятий высокий приоритет, как было отмечено, могут иметь социальные аспекты развития, экологические проблемы и тому подобное. 
Относительное меньшинство предприятий раскрывают сведения по системе управления и политике. Формулирование ценности организаций способствует определению их подходов к управлению, долгосрочных стратегий и представлению ведения руководства на предмет адекватных управленческих решений. Так, ПАО «Магнитогорский металлургический комбинат» (далее - ПАО «ММК») отмечает, что корпоративная концепция предприятия базируется на обеспечении безопасных и здоровых условий труда как одного из важнейших трудовых прав сотрудников, а также направления социальной активности в ПАО «ММК» традиционно относятся на социальную поддержку инвалидов, неработающих пенсионеров и других слабозащищенных категорий граждан моногорода [54].

В свою очередь, градообразующее предприятие ПАО «Северсталь» города Череповца помимо социальных вложений в повышение качества жизни работников также направляет свою социальную активность в сторону местных сообществ и сохранения окружающей среды [55]. Значительные суммы «Северсталь» инвестирует в региональную социальную инфраструктуру городов, на территориях которых ее предприятия осуществляют свою деятельность. Тем самым акционерное общество обеспечивает благоприятную среду для реализации долгосрочной стратегии своего развития, снижая остроту социальных проблем в Череповце. Градообразующее предприятие АК «АЛРОСА» также считает, что благополучие людей и регионов невозможно и без охраны окружающей среды. АК «АЛРОСА» стремится минимизировать негативное воздействие на экологию и рационально использовать ресурсы [56].

Общепринятым индикатором социальной эффективности градообразующих предприятий являются показатели вклада налоговых поступлений в формирование бюджетов различного уровня. Так, АК «АЛРОСА» стремится заботиться не только о сотрудниках самой компании, но и обо всех жителях регионов, где ведется работа. 
Для Республики Саха АК «АЛРОСА» является крупнейшим работодателем и крупнейшим налогоплательщиком, формируя значительную часть налоговых доходов бюджета региона. В 2017 году налоговые отчисления АЛРОСА в республике составили более 32,5 млрд рублей. Еще более 12,7 млрд рублей республика и ее улусы получили в виде дивидендов [56]. Также среди крупнейших налогоплательщиков моногородов отмечена и компания ПАО «Северсталь», которая входит в топ-50 крупнейших налогоплательщиков России. В бюджеты и внебюджетные фонды от предприятий Компании в 2017 году поступили средства в размере около 46,2 млрд рублей [55]. ПАО «Магнитогорский металлургический комбинат» также является одним из крупнейших налогоплательщиков в Челябинской области, а в г. Магнитогорске - крупнейшим работодателем и налогоплательщиком.

Также существующие практики по стратегическому управлению КСО основываются на принципе соблюдения прав человека для всех категорий заинтересованных сторон. Например, для организаций потребительского сектора признаком социально направленного бизнеса может быть бережное отношение к клиентам с ограниченными возможностями или помощь в социальной адаптации подобной категории сотрудников.

Практики корпоративного обучения сотрудников являются одним из направлений, которое, как правило, наиболее полно отражается в социальных нефинансовых отчетах. Ежегодно промышленные предприятия вкладывают миллионы рублей в своих работников на их переподготовку и повышение квалификации. А также эти компании выстраивают внутрикорпоративную комплексную систему обучения, привнося свой вклад в формирование общего фонда финансирования проектов по развитию человеческого и интеллектуального капитала на региональном, а иногда и национальном уровне. Организации, как правило, декларируют, что программы корпоративного образования 
реализуются за счет поддержки работников среднего и высшего образования, а также инновационного потенциала образовательных и научных учреждений [53, с. 99].

Типичным примером для оценки практик корпоративного обучения сотрудников может стать ПАО «Северсталь», предприятие наиболее полно раскрывает данные об обучении и его результативности. В 2017 году затраты на обучение персонала возросли на 35\% по сравнению с предыдущим периодом и составили 313 млн руб. [55]. $80 \%$ затрат пришлось на обучение руководителей, специалистов и служащих, 20\% - на обучение рабочих. В основном рост затрат на обучение связан с проведением новых крупных программ для руководителей, а также с началом процесса верификации резервистов на управленческие позиции и со стартом новой Лидерской программы ПАО «Северсталь».

Как видно из таблищы 8, предприятие анализирует результативность корпоративного обучения сотрудников посредством его влияния на карьерное продвижение. При этом показатель социального развития за счет вложений в человеческий и интеллектуальный капитал является достаточно прозрачным и надежным при оценке.

Показатели, приведенные в таблице 8, показывают, что социальные вложения градообразующего предприятия ПАО «Северсталь» в городе присутствия Череповце на обучение и развитие обладают высокой эффективностью - порядка 50-60\% всех работников по результатам обучения получают карьерное продвижение. Более половины среднесписочной численности сотрудников обучаются на внутрикорпоративной основе, ПАО «Северсталь» также задействует внешние обучающие организации. Уровень вовлечения работников предприятия в программы корпоративного и внешнего обучения приближается к 35\%, что говорит об удовлетворительной динамике. 
Показатели социальной активности ПАО «Северсталь» в городе присутствия Череповце, относящиеся к внутренней социальной среде, раскрываемые в нефинансовой отчетности в 2016-2018 годах [55]

\begin{tabular}{|l|c|c|c|c|}
\hline \multicolumn{1}{|c|}{ Показатели } & $\begin{array}{c}\text { Еди- } \\
\text { ница } \\
\text { изме- } \\
\text { рения }\end{array}$ & 2016 & 2017 & 2018 \\
\hline Общая численность персонала & чел. & 29267 & 28906 & 29172 \\
\hline $\begin{array}{l}\text { Количество сотрудников, прошедших } \\
\text { обучение }\end{array}$ & чел. & 8814 & 7971 & 10437 \\
\hline $\begin{array}{l}\text { Сотрудники, получившие обучение } \\
\text { на внутрикорпоративной учебной базе }\end{array}$ & чел. & 6101 & 4012 & 5907 \\
\hline $\begin{array}{l}\text { Из них получили повышение разряда } \\
\text { или повышение в должности }\end{array}$ & чел. & 4018 & 2988 & 5312 \\
\hline Затраты на обучение сотрудников & $\begin{array}{l}\text { тыс. } \\
\text { руб. }\end{array}$ & 1947 & 1139 & 2640 \\
\hline $\begin{array}{l}\text { Затраты на обучение в расчете на од- } \\
\text { ного обученного сотрудника }\end{array}$ & $\begin{array}{l}\text { тыс. } \\
\text { руб. }\end{array}$ & 0,221 & 0,143 & 0,253 \\
\hline
\end{tabular}

Вопросы по здравоохранению, в том числе по улучшению здоровья сотрудников и членов их семей, являются также приоритетным направлением корпоративной социальной ответственности. Существующие программы в данной области разделены на три направления, которые имеют практическую значимость для градообразующего предприятия и моногорода. Первым из этих направлений является укрепление и поддержание здоровья работников, а также профилактика заболеваний (в том числе профзаболеваний) с целью снижения рисков потери временной нетрудоспособности на предприятии. В рамках данного направления КСО могут быть отнесены мероприятия спортивного характера, предоставление профилактического лечения в специализированных учреждениях и организация летнего отдыха [53, с. 105]. Ко второму направлению социальной ответственно- 
сти градообразующих предприятий в области здравоохранения относится помощь работникам в лечении уже возникших заболеваний (оплата лечения на частичной или полной основе, вложения во внутреннюю медицинскую инфраструктуру). По третьему направлению в данной области осуществляется дополнительное медицинское страхование, которое направлено на поддержание обязательных стандартов предоставления медицинских услуг в соответствии с внутренней корпоративной политикой, а также сокращение возможных рисков, связанных с использованием человеческого капитала и капитала здоровья.

Уделение внимания закреплению позиций в рамках инвестирования в здоровье работников большинством промышленных градообразующих предприятий обуславливается рядом причин. В первую очередь значительная часть промышленных предприятий концентрируют опасные и вредные для здоровья производства (преимущественно химическая промышленность и металлургия), способствующие возникновению хронических заболеваний сотрудников, которые становятся определенными профзаболеваниями в каждой отрасли. Работа на некоторых производствах также сопряжена с повышенной нагрузкой на все системы организма работников и с деятельностью в тяжелых природно-климатических условиях, что приводит к повышенной заболеваемости, временной нетрудоспособности и сокращению ожидаемой и продолжительности здоровой жизни сотрудников [53, с. 105]. Второй причиной является уровень качества доступных медицинских услуг населению в рамках обязательного медицинского страхования, который остается достаточно низким. Предприятия стремятся поддерживать социальную инфраструктуру любыми доступными для ним способами (например, создание медсанчасти, корпоративных профилакториев и т. п.). Часть компаний производят оплату специальных медицинских услуг и медицинских осмотров, таких как вакцинация от различных инфекционных заболеваний, стома- 
тологическое лечение и другое. Также важную роль играют мероприятия по пропаганде здорового образа жизни, проводимые предприятиями для своих сотрудников и жителей моногорода (в частности, проведение подобных мероприятий на предприятии ПАО «ММК»).

Экологическая эффективность также является значимым объектом в ходе реализации КСО. Общий объем экологической отчетности, отведенной оценке влияния промышленных предприятий на окружающую среду и регионы присутствия растет в глобальном масштабе стремительнее по сравнению с количеством социальных отчетов [53, с. 107]. В разные годы экологические отчеты составляли порядка 60$80 \%$ всей публикуемой предприятиями нефинансовой отчетности [57]. Тем не менее со временем прослеживается тенденция объединения социальной и экологической отчетности в единую отчетность об устойчивом развитии.

Регулярно экологические отчеты публикуются многими промышленными компаниями внутри интегрированных отчетов или в самостоятельной форме. Компания АК «АЛРОСА» ежегодно публикует самостоятельные социально-экологические отчеты с 2011 года, уделяя данному процессу особое внимание. Приоритетные направления в области природоохранной деятельности организации имеют отношение к поддержке социально-экономического развития, которое бы способствовало минимизации ущерба окружающей среде и сохранению природной, а также обеспечению экологической безопасности строительства новых объектов [53, с. 109].

В ПАО «Корпорация ВСМПО-АВИСМА», следуя принципам экологической политики, созданы условия и принимаются необходимые меры для защиты окружающей среды посредством [58]:

- систематического обучения персонала в области экологии;

- соблюдения персоналом экологических требований при производственной деятельности; 
- проведения мероприятий, позволяющих снизить или сохранить на допустимом уровне негативное воздействие экологических аспектов, образующихся в результате деятельности предприятия;

- снижения риска возникновения аварийных ситуаций и их негативного воздействия на окружающую среду;

- открытого сотрудничества в области охраны окружающей среды с заинтересованными организациями и общественностью;

- рационального использования электроэнергии, воды, природного газа и отходов производства.

Проектом Всемирного фонда дикой природы (WWF) России и «Национального Рейтингового Агентства» опубликован Экологический рейтинг горнодобывающих и металлургических компаний России за 2018 год, в числе которых также есть градообразующие предприятия (табл. 9) [59].

Таблицุа 9

Экологический рейтинг горнодобывающих и металлургических компаний России (по состоянию на декабрь 2018 года)

\begin{tabular}{|c|l|c|}
\hline $\begin{array}{c}\text { Итого- } \\
\text { вое ме- } \\
\text { сто }\end{array}$ & \multicolumn{1}{|c|}{ Наименование } & $\begin{array}{c}\text { Итоговый балл } \\
\text { рейтинга }\end{array}$ \\
\hline 1 & Кинросс голд (Kinross Gold) & 1,59 \\
\hline 2 & Полюс Золото & 1,43 \\
\hline 3 & СДС-Уголь & 1,42 \\
\hline 4 & Полиметалл & 1,33 \\
\hline 5 & Архангельскгеолдобыча & 1,32 \\
\hline 6 & Металлоинвест & 1,30 \\
\hline 7 & Северсталь & 1,28 \\
\hline 8 & АЛРОСА & 1,25 \\
\hline 9 & Норильский никель, ГМК & 1,24 \\
\hline 10 & Новолипецкий металлургический комбинат & 1,17 \\
\hline 11 & Русал & 1,16 \\
\hline 12 & СУЭК & 1,10 \\
\hline 13 & Магнитогорский металлургический комбинат & 1,08 \\
\hline
\end{tabular}


Цель составления данного рейтинга - способствовать повышению эффективности использования природных ресурсов и снижению нагрузки на окружающую среду, а также ведению социально ответственного бизнеса в России.

Данный рейтинг осуществляется на основе параметров (критериев), которые сформулированы в первую очередь в Основных положениях политики социальной и экологической ответственности горнодобывающих компаний, а также в ряде международных документов [59].

Рейтинг рассчитывается по всем сегментам - от обустройства месторождения и добычи вплоть до переработки полезных ископаемых. Показатели рейтинга базируются на сведениях о деятельности предприятий в Российской Федерации, опубликованных на русском языке. Под данными, размещенными в публичном пространстве, следует считать данные из годовой социально-экологической и финансовой отчетности, а также докладов об охране окружающей среды (в т. ч. региональных), находящихся в свободном доступе. При этом публикация документов в сети Интернет на официальных сайтах организации (включая дочерние общества и подрядные организации) с обязательным включением ссылок на соответствующие страницы в меню (оглавлении) сайта и интервью официальных представителей предприятий для региональных и федеральных СМИ [59].

Качество НМА предприятия, в свою очередь, является важным направлением раскрытия в отчетности, и характерно только для нефинансовых отчетов, имеющих наибольшее значение. Организации в этом аспекте декларируют сведения о применяемых системах управления, качестве внутренних бизнес-процессов, инновационной деятельности и дальнейших перспективных планах реконструкции и технологической модернизации. Такая информация носит косвенный характер, при оценке эффективности КСО дает понимание 
о намерениях предприятия продолжать стратегическое развитие и демонстрировать свою социальную активность в долгосрочной перспективе. Социальная отчетность дает возможность определять уровень целостности социального, экономического и интеллектуального элементов стратегического потенциала организации, а также связывать показатели результативности в сферах, на первый взгляд, принципиально различных интересов [53, с. 109].

Компания ПАО «Северсталь» в своей нефинансовой отчетности раскрывает основные направления научно-исследовательских работ и публикует информацию о коммерциализации объектов интеллектуальной собственности. Данное предприятие является крупнейшим в отрасли разработчиком и поставщиком новых технологий. На 1 января 2018 года портфель интеллектуальной собственности насчитывал 486 патентов, действующих на территории Российской Федерации [55].

В свою очередь, инновационный и научно-проектный комплекс «АЛРОСА» возглавляет научно-исследовательский и проектный институт алмазодобывающей промышленности «Якутнипроалмаз» АК «АЛРОСА». Институт развивает три основных направления научно-техническое, проектно-изыскательское и технико-экономическое. В частности, Институт ведет работу в области применения новых технологий при алмазодобыче, а также реализует Программу инновационного развития и технологической модернизации АК «АЛРОСА».

Также значительно важными направлениями корпоративной социальной ответственности градообразующих предприятий являются благотворительность и спонсорство [49, с. 61]. Большое количество организаций создают отдельные разделы социальной отчетности, посвященные данному направлению. При этом анализ практики социальных вложений показывает, что объем совокупных средств, направленных на благотворительность в российских условиях, зачастую 
во много раз превышает затраты на обучение сотрудников. Спонсорство и благотворительность отражают политику компании в области развития территорий присутствия и взаимодействия с внешним сообществом [53, с. 110]. Главной целью таких социальных вложений является взаимодействие с местным сообществом в регионах присутствия и создание условий нормального воспроизводства человеческих ресурсов. Помимо этого, мероприятия по благотворительности и спонсорству поддерживают имидж предприятий и вносят вклад в формирование практик социально ответственного поведения.

Разнообразие социальных и благотворительных программ, реализуемых Магнитогорским металлургическим комбинатом и организациями Группы ПАО «ММК», охватывает практически все стороны жизни работников предприятия, а также распространяется на пенсионеров и ветеранов. К числу основных направлений социальной деятельности в Группе ПАО «ММК» традиционно относится социальная поддержка неработающих пенсионеров, инвалидов и других слабозащищенных категорий граждан. В 2017 году Группа ПАО «ММК» направила на реализацию социальных программ и проектов, а также на благотворительность около 2,24 млрд рублей, что на 4\% выше показателя предыдущего года [54].

ПАО «Северсталь» осуществляет затраты на благотворительность, в том числе через [55]:

- безвозмездную помощь в виде работ/услуг;

- финансовую и имущественную поддержку организаций и фондов;

- участие в некоммерческих и саморегулируемых организациях;

- прочие проекты.

На рисунке 12 представлена динамика расходов на благотворительность и спонсорство анализируемых градообразующих предприятий за 2016-2018 гг. 


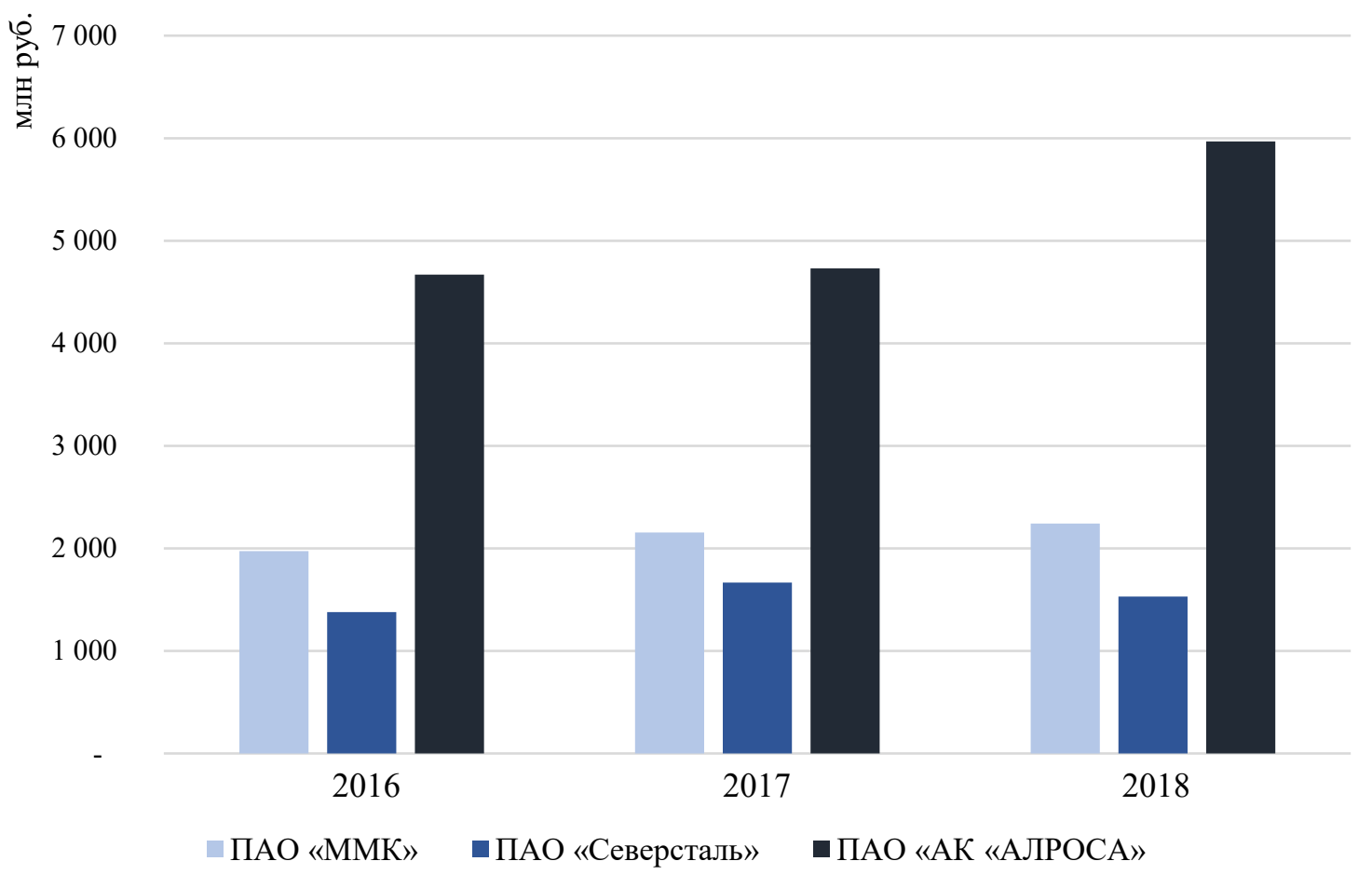

Рисунок 12. Социальные вложения промышленных градообразующих предприятий, направленные на благотворительность и спонсорство, за 2016-2018 гг., млн руб.

Из представленного рисунка видно, что градообразующие предприятия с каждым годом увеличивают расходы на благотворительность и спонсорство в городах присутствия. Положительным моментом также является то, что компании раскрывают информацию о направлениях затрат на благотворительные проекты в нефинансовой отчетности, что повышает прозрачность их деятельности в области корпоративной социальной ответственности.

Российскими предприятиями практика социального аудита в настоящее время еще достаточно не закрепилась. Процессы социального аудита направлены на идентификацию и подтверждение документально оформленных процессов управления и достоверность данных, которые представлены в нефинансовой отчетности [53, с. 115]. Социальный аудит представляет собой неотъемлемый этап 
формирования и развития системного подхода к КСО и планирования социальных вложений и результативности их применения. По результатам аудита, который проводится на независимой основе, формируется заключение. Как отмечают исследователи, принято считать, что проведение социального аудита отчетности представляет собой необоснованные затраты, а также значительно влияет на стоимость подготовки самой отчетности. Но на практике полученные эффекты от увеличения доверия к социальной отчетности по отношению к затратам, в особенности для крупных предприятий, довольно высоки [59, c. 22].

Для социального аудита должна быть четко установлена процедурная сторона процесса, выявлены и унифицированы соответствующие термины и понятия, которые используются в ходе проведения аудита, и методика оценки достижения конкретных показателей эффективности КСО [53, с. 116]. Также необходимо определить способы взаимодействия аудиторов и представителей предприятия, а также предмет и требуемые границы верификации социальной информации. Для большинства организаций соблюдение подобных условий связано с дополнительными, нерациональными с их точки зрения, затратами. Тем не менее практика заверения нефинансовой отчетности усиливается с каждым годом, пусть и не такими темпами, как прирост количества самих отчетов.

Как правило, практика проведения аудита показывает низкую достоверность раскрываемой информации, возникающей из-за небрежности в подготовке социальной отчетности - неадекватным или несопоставимым отражением статистической информации, искажением показателей системы GRI. Данное замечание касается, например, показателя заработной платы - компании в большинстве случаев сопоставляют показатель средней заработной платы в организации и в регионе, в то время как стандарт требует сравнения минимального 
начального уровня заработной платы на предприятии и минимального размера оплаты труда в регионе. Некоторые предприятия предпочитают самостоятельное общественное заверение декларируемой отчетности, а большинство отчетов, как правило, не включают в себя аудиторских заключений.

Проведя анализ уровня развития корпоративной социальной ответственности промышленных градообразующих предприятий России, можно сделать вывод, что российские промышленные компании моногородов расширили спектр инструментов, подходов и технологий для поддержания социально ответственного поведения. На ряде предприятий сформированы устойчивые системы управления социальной деятельности и, что важно, накоплен положительный опыт социальных вложений и поддержки общественных программ [53, с. 117]. Несмотря на данное развитие КСО градообразующих предприятий, проблемы промышленных моногородов сохраняются, а в некоторых аспектах даже увеличиваются. Так, к наиболее острым дисбалансам можно отнести: безработицу, преступность, рост заболеваемости, сокращение продолжительности жизни, миграцию, увеличение объемов ветхого и аварийного жилья, загрязнение окружающей среды и др. Также исходя из проблем моногорода возникают и проблемы самих градообразующих предприятий, такие как увеличение заболеваемости, миграция, ведут к потерям рабочего времени, снижению производительности труда и к другим негативным экономическим явлениям.

Анализ численности населения моногородов, предприятия которых ведут социально направленный бизнес (рис. 13), показывает, что количество жителей монопрофильных городов с каждым годом сокращается. Так, в Верхнесалдинском городском округе численность населения непрерывно сокращается, при этом наблюдается положительная динамика затрат на КСО градообразующего предприятия ПАО «Корпорация «ВСМПО-АВИСМА». 


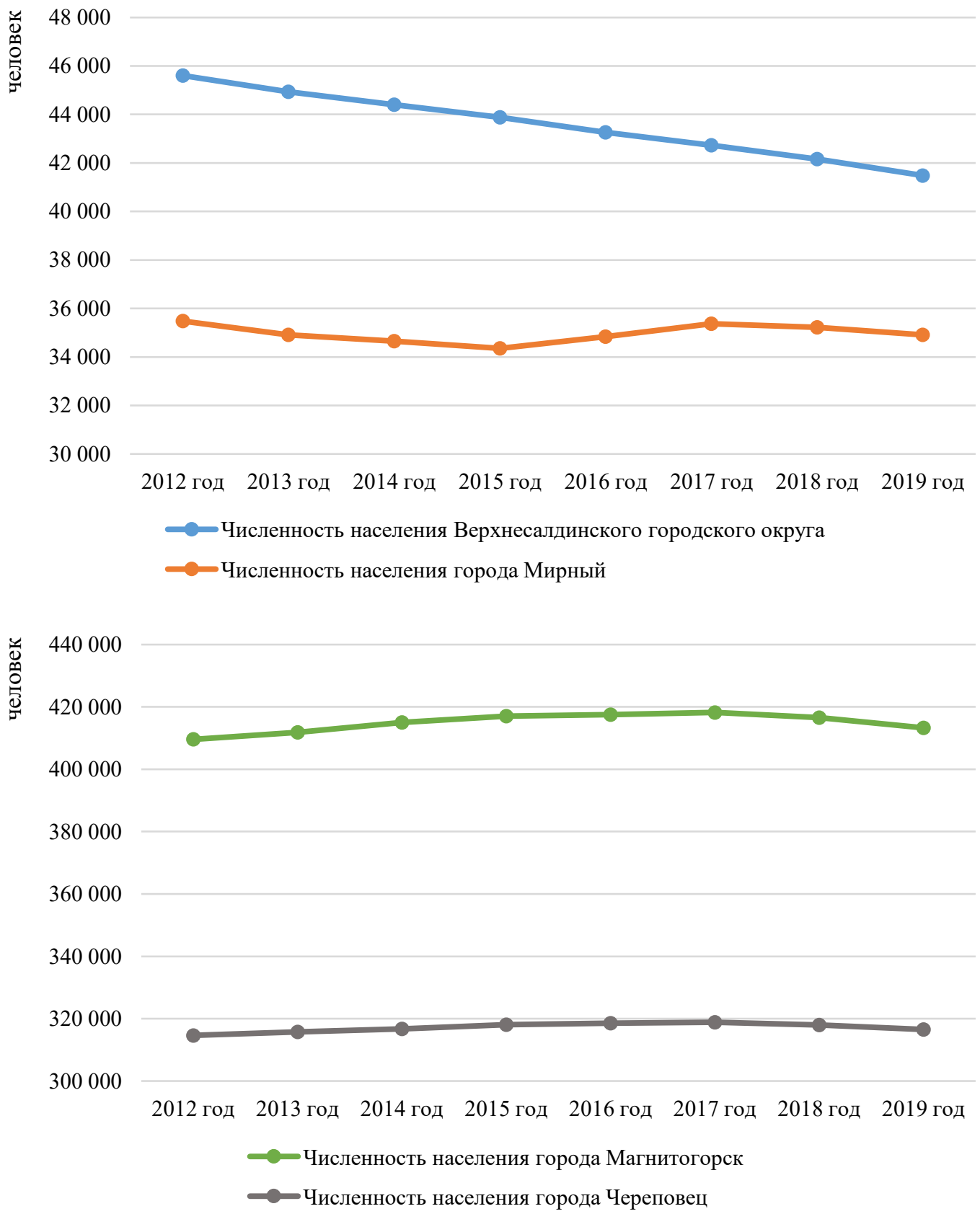

Рисунок 13. Динамика численности населения исследуемых моногородов, 2012-2019 гг. [60]

Рассматривая уровень заболеваемости жителей исследуемых моногородов (puc. 14), также наблюдается негативная динамика. Количество обращений за медицинской помощью в моногородах за 2016-2018 гг. имеет тенденцию роста. 


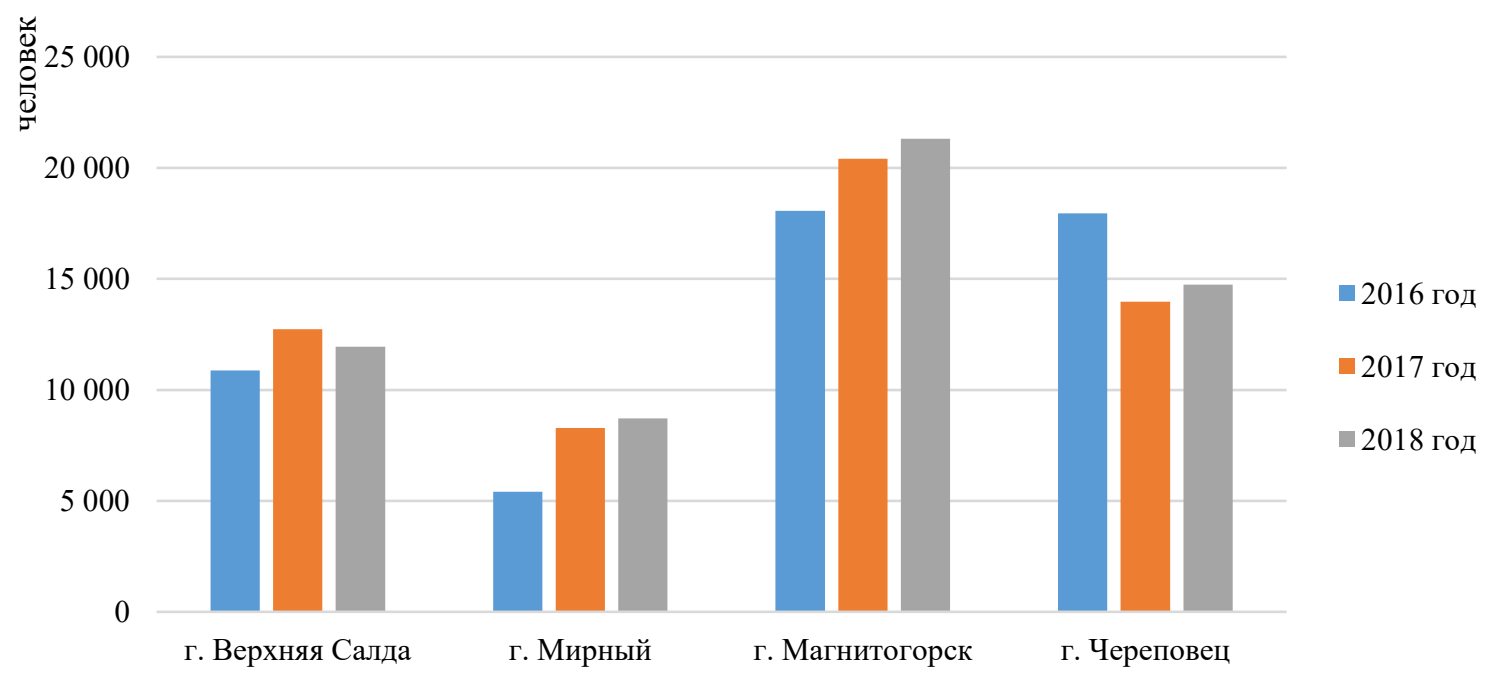

Рисунок 14. Заболеваемость населения исследуемых монопрофильных городов, 2016-2018 гг.

При анализе уровня заболеваемости жителей моногородов также необходимо рассматривать динамику уровня заболеваемости сотрудников внутри градообразующего предприятия и их структуру.

Проведя анализ заболеваемости по больничным листам одного цеха АО «Корпорация ВСМПО-АВИСМА» за 2017-2019 гг. (рис. 15), можно сделать вывод, что в исследуемый период динамика уровня заболеваемости сотрудников увеличивается, что сказывается на общей длительности нетрудоспособности в организации.

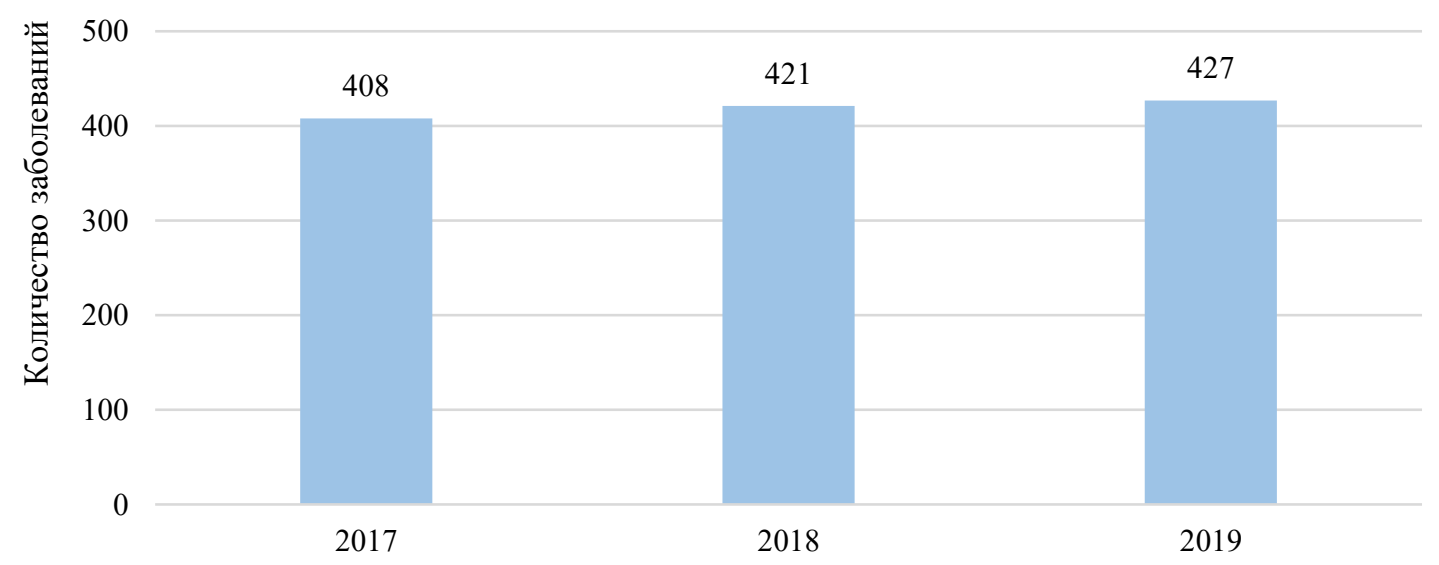

Рисунок 15. Показатели заболеваемости по больничным листам по одному цеху АО «Корпорация ВСМПО-АВИСМА» за 2017-2019 гг. 
При анализе структуры заболеваемости сотрудников одного из цехов АО «Корпорация ВСМПО-АВИСМА» выделены основные заболевания, представленные в таблице 10.

Таблица 10

\section{Структура заболеваемости по больничным листам по одному цеху АО «Корпорация ВСМПО-АВИСМА» за 2019 г.}

\begin{tabular}{|c|l|c|}
\hline № п/п & \multicolumn{1}{|c|}{ Причина нетрудоспособности } & $\begin{array}{c}\text { Количество заболе- } \\
\text { ваний за период, } \\
\text { случаи }\end{array}$ \\
\hline 1 & Инфекционные болезни & 8 \\
\hline 2 & Новообразования & 4 \\
\hline 3 & Болезни крови & 0 \\
\hline 4 & Болезни нервной системы & 5 \\
\hline 5 & Болезни глаза & 4 \\
\hline 6 & Болезни уха & 36 \\
\hline 7 & Болезни системы кровообращения & 139 \\
\hline 8 & Болезни органов дыхания & 30 \\
\hline 9 & Болезни органов пищеварения & 6 \\
\hline 10 & Болезни кожи & 107 \\
\hline 11 & $\begin{array}{l}\text { Болезни костно-мышечной системы (остеохон- } \\
\text { дрозы, артриты) }\end{array}$ & 4 \\
\hline 12 & Болезни мочеполовой системы & 76 \\
\hline 13 & Травмы, отравления & 427 \\
\hline & Всего по заболеваниям & \\
\hline
\end{tabular}

Исходя из данных таблищы 10, можно сделать вывод, что в общей структуре заболеваемости работников одного цеха градообразующего предприятия АО «Корпорация ВСМПО-АВИСМА» основная доля приходится на болезни органов дыхания - 32,55\% и болезни костно-мышечной системы (остеохондрозы, артриты) - 25,05\%, которые относятся к профзаболеваниям сотрудников в данной промышленности. Что, в свою очередь, говорит о необходимости уделения большего внимания данным категориям в рамках осуществления корпоративной социальной ответственности. 
Проведенный в практической главе обзор практик социальных вложений показал, что за предшествующие 15 лет российские промышленные градообразующие предприятия расширили спектр инструментов, подходов и технологий для поддержания социально ответственного поведения бизнеса. На ряде предприятий сформированы устойчивые системы управления социальной деятельностью и, что важно, накоплен положительный опыт социальных вложений и поддержки общественных программ. Анализ индикаторов социального инвестирования и уровень применяемых технологий управления социальной деятельностью российских промышленных организаций показывает, что крупные компании реализуют программы КСО на одном уровне с финансовыми корпорациями и зарубежными промышленными предприятиями.

Для российских градообразующих предприятий одним из приоритетных направлений является сохранение окружающей среды и вложения в человеческий капитал (в том числе капитал здоровья и интеллектуальный капитал), однако основным барьером для осуществления подобной деятельности является высокий уровень затрат и сложность оценки их экономической эффективности. А также увеличение затрат промышленных градообразующих предприятий на корпоративную социальную ответственность не всегда дает положительный результат. Рост заболеваемости жителей моногородов, сокращение численности населения указывают на несовершенство системы КСО данных предприятий.

Таким образом, проведенный анализ подтверждает выдвинутую в теоретической главе гипотезу о том, что несмотря на существующее развитие КСО промышленных градообразующих предприятий, в моногородах сохраняется отрицательная динамика социально значимых показателей. Из этого вытекает необходимость в разработке инструментария развития корпоративной социальной ответственности промышленных предприятий моногородов, включающего в себя оценку 
социально-экономических показателей для последующего, более грамотного выбора направления инвестиций в КСО таких предприятий.

Проведенный анализ также показал, что существует необходимость в создании иного экономического подхода к оценке КСО и распределению имеющихся у градообразующих предприятий финансовых средств, уделяя больше внимания социальным аспектам как на предприятии, так и в самом моногороде.

Исходя из этого, следует, что оценка эффективности КСО должна содержать все необходимые параметры социальной ответственности бизнеса в монопрофильных городах, а также должна базироваться не на произвольном наборе коэффициентов, а на показателях, характеризующих именно те аспекты деятельности, которые имеют существенное значение для социальной ответственности градообразующих предприятий. К таким показателям можно отнести:

- соотношение среднемесячной заработной платы работников градообразующего предприятия и в регионе;

- использование рабочих по квалификации;

- уровень технологической модернизации производства;

- стабильность кадров;

- условия производственного быта и повышения безопасности условий труда работников градообразующего предприятия;

- обеспеченность жильем сотрудников и населения моногорода;

- обеспеченность лечебно-оздоровительными учреждениями;

- обеспеченность детскими учреждениями в моногороде;

- обеспеченность спортивными сооружениями, культурно-просветительскими учреждениями;

- уровень благоустройства территории монопрофильного муниципального образования. 
Также в рамках оценки КСО организаций существует необходимость в построении некоего графика, который мог бы дать наглядное представление и зрительную оценку, как выглядит обобщенный критерий корпоративной социальной ответственности каждого градообразующего предприятия. Преимуществом такого методического подхода является то, что он комплексный и учитывает наибольшее количество факторов, которые влияют на КСО градообразующего предприятия.

Проведение многомерного рейтингового анализа позволит сделать вывод, что принадлежность предприятия к территориальному местоположению и социально-экономическая ситуация муниципального образования, в котором предприятие осуществляет свою деятельность, оказывают существенное влияние не только на уровень социальной политики, но и на выбор направлений социальных инвестиций.

Таким образом, по нашему мнению, разработка такого инструментария позволит градообразующим предприятиям проводить самоанализ, оценивая социально-экономические показатели деятельности для дальнейшего выбора направлений социального проектирования и инвестирования в КСО. Все это положительно повлияет на финансово-хозяйственную деятельность предприятия, его конкурентоспособность и инвестиционную привлекательность самого градообразующего предприятия и моногорода в целом. 


\section{3. РАЗРАБОТКА МЕТОДИЧЕСКОГО ИНСТРУМЕНТАРИЯ РАЗВИТИЯ КОРПОРАТИВНОЙ СОЦИАЛЬНОЙ ОТВЕТСТВЕННОСТИ ПРОМЫШЛЕННЫХ ПРЕДПРИЯТИЙ В МОНОГОРОДАХ}

\section{1. Подход к выбору экономических показателей для оценки состояния корпоративной социальной ответственности промышленного градообразующего предприятия}

Проведенный анализ уровня развития корпоративной социальной ответственности промышленных градообразующих предприятий Российской Федерации и анализ последствий такой деятельности внутри моногородов выявил необходимость разработки инструментария развития КСО данных предприятий. В качестве первого этапа разработки такого методического инструментария требуется провести оценку социально-экономических показателей для дальнейшего выбора поведения в рамках социальной политики предприятий.

Осуществление эффективной социальной политики в нынешних условиях оказывает большое влияние почти на все значимые экономические и социальные показатели деятельности градообразующего предприятия, имеет положительный общественный эффект и приносит ему дополнительную прибыль. Тем не менее стоит отметить, что единого общепринятого методического подхода к оценке эффективности корпоративной социальной ответственности градообразующих предприятий в экономической науке на сегодняшний день не сформулировано.

По мнению различных авторов, оценка КСО бизнеса должна формироваться на определенном наборе показателей. На основании того, что исследование социальной ответственности предприятий возможно только посредством использования системы показателей, которые дают числовое измерение качественных и количественных 
характеристик объекта, тенденций их измерений и связей между ними, то представляется целесообразным осуществление комплексной оценки всех факторов социальной ответственности.

В.Н. Шитов и О.Ф. Цымбалист считают, что на практике для такой оценки возможно применение следующих методов [61]:

- метод сумм отобранных показателей (например, суммируются темпы прироста показателей);

- средняя арифметическая взвешенная (темпы прироста суммируются с учетом веса каждого отобранного параметра по какому-либо принципу);

- метод балльной оценки (каждый показатель имеет свой весовой балл, затем в баллах оцениваются приращения показателей по определенной шкале);

- метод ранжирования (суммируются места, достигнутые организациями по отобранным параметрам);

- методы рейтинговой оценки;

- графические методы.

На наш взгляд, оценка корпоративной социальной ответственности градообразующих предприятий может быть проведена на основании рейтинга организаций с учетом совокупного влияния всех факторов КСО бизнеса.

В основе формирования рейтинга компании лежит набор социально-экономических показателей. Коэффициенты, которые входят в этот набор, оцениваются в баллах, при этом их высота определена значением данного показателя в качестве критерия оценки и степенью соответствия нормативному, количественно выраженному уровню [49]. 
Для оценки состояния КСО предприятий в моногородах нами предлагается использование метода многомерного рейтингового анализа, который подразумевает алгоритм, состоящий из нескольких этапов.

На первом этапе обосновывается система коэффициентов, с помощью которых будет оцениваться состояние КСО градообразующего предприятия, осуществляется сбор данных по этим параметрам, а также формируется матрица исходных данных. При этом оценка эффективности КСО должна содержать все необходимые параметры корпоративной социальной ответственности бизнеса в монопрофильных городах, а также должна базироваться не на произвольном наборе коэффициентов, а на показателях, характеризующих именно те аспекты деятельности, которые имеют существенное значение для КСО градообразующих предприятий.

После проведенных исследований в ходе разработки инструментария развития КСО градообразующих предприятий нами были выделены показатели, которые необходимы для оценки корпоративной социальной ответственности промышленных предприятий в моногородах (табл. 11).

Рассчитанные значения коэффициентов, имеющих различные единицы измерения и размерность, приводятся в сопоставимый вид. Для этого по каждому показателю приводится сравнение с условным эталонным предприятием, имеющим наилучшие показатели (то есть рекомендуемые, оптимальные значения всех рассматриваемых показателей). Эталоном сравнения является самое социально ориентированное предприятие, достигшее в данном аспекте деятельности наилучших результатов [61, с. 60]. 


\section{Матрица группировки исходных данных оценки показателей КСО градообразующих предприятий}

\begin{tabular}{|c|c|c|c|c|c|}
\hline \multirow{2}{*}{ Показатель } & \multicolumn{5}{|c|}{$\begin{array}{c}\text { Соответствие значения показателя ито- } \\
\text { говому баллу }\end{array}$} \\
\hline & 1 балл & $\begin{array}{c}2 \\
\text { балла }\end{array}$ & $\begin{array}{c}3 \\
\text { балла }\end{array}$ & $\begin{array}{c}4 \\
\text { балла }\end{array}$ & $\begin{array}{c}5 \text { бал- } \\
\text { лов }\end{array}$ \\
\hline $\begin{array}{l}\text { Коэффициент повышения квали- } \\
\text { фикации кадров }\end{array}$ & $\geq 0,20$ & $\geq 0,40$ & $\geq 0,60$ & $\geq 0,80$ & $=1,0$ \\
\hline $\begin{array}{l}\text { Коэффициент использования рабо- } \\
\text { чих по квалификации }\end{array}$ & $\geq 0,20$ & $\geq 0,40$ & $\geq 0,60$ & $\geq 0,80$ & $=1,0$ \\
\hline $\begin{array}{l}\text { Коэффициент соотношения сред- } \\
\text { немесячной заработной платы ра- } \\
\text { ботников градообразующего пред- } \\
\text { приятия и в регионе }\end{array}$ & $\geq 0,20$ & $\geq 0,40$ & $\geq 0,60$ & $\geq 0,80$ & $=1,0$ \\
\hline $\begin{array}{l}\text { Коэффициент технологической мо- } \\
\text { дернизации производства }\end{array}$ & $\geq 0,20$ & $\geq 0,40$ & $\geq 0,60$ & $\geq 0,80$ & $=1,0$ \\
\hline Коэффициент стабильности кадров & $\geq 0,40$ & $\geq 0,50$ & $\geq 0,60$ & $\geq 0,70$ & $=0,80$ \\
\hline $\begin{array}{l}\text { Коэффициент условий производ- } \\
\text { ственного быта и повышения без- } \\
\text { опасности условий труда работни- } \\
\text { ков градообразующего предприя- } \\
\text { тия }\end{array}$ & $\geq 0,20$ & $\geq 0,40$ & $\geq 0,60$ & $\geq 0,80$ & $=1,0$ \\
\hline $\begin{array}{l}\text { Коэффициент обеспеченности са- } \\
\text { нитарно-бытовыми помещениями }\end{array}$ & $\geq 0,20$ & $\geq 0,40$ & $\geq 0,60$ & $\geq 0,80$ & $=1,0$ \\
\hline $\begin{array}{l}\text { Коэффициент обеспеченности жи- } \\
\text { льем сотрудников и населения мо- } \\
\text { ногорода }\end{array}$ & $\geq 0,20$ & $\geq 0,40$ & $\geq 0,60$ & $\geq 0,80$ & $=1,0$ \\
\hline $\begin{array}{l}\text { Коэффициент обеспеченности ле- } \\
\text { чебно-оздоровительными учрежде- } \\
\text { ниями }\end{array}$ & $\geq 0,20$ & $\geq 0,40$ & $\geq 0,60$ & $\geq 0,80$ & $=1,0$ \\
\hline $\begin{array}{l}\text { Коэффициент обеспеченности дет- } \\
\text { скими учреждениями в моногороде }\end{array}$ & $\geq 0,20$ & $\geq 0,40$ & $\geq 0,60$ & $\geq 0,80$ & $=1,0$ \\
\hline $\begin{array}{l}\text { Коэффициент обеспеченности } \\
\text { спортивными сооружениями куль- } \\
\text { турно-просветительскими учре- } \\
\text { ждениями }\end{array}$ & $\geq 0,20$ & $\geq 0,40$ & $\geq 0,60$ & $\geq 0,80$ & $=1,0$ \\
\hline $\begin{array}{l}\text { Коэффициент благоустройства тер- } \\
\text { ритории монопрофильного муни- } \\
\text { ципального образования }\end{array}$ & $\geq 0,20$ & $\geq 0,40$ & $\geq 0,60$ & $\geq 0,80$ & $=1,0$ \\
\hline
\end{tabular}


Интегральный показатель комплексной оценки, определяемый методом сумм, предполагает суммирование фактических значений и рассчитывается для каждого градообразующего предприятия по следующей формуле [61]:

$$
K=\sum_{i=1}^{n} x_{i j}^{\phi} / x_{i j}^{\sigma}
$$

где $\mathrm{n}$ - количество показателей;

$x_{i j}^{\phi}, x_{i j}^{\sigma}-$ фактическое и базисное значения i-го показателя для jго предприятия соответственно.

Для установления объективных сопоставимых числовых значений показателей в подобных случаях применяется метрическая шкала отношений [61, с. 61]. По каждой положительной характеристике в матрице находится максимальное значение и принимается за эталонное (5 баллов). Коэффициентам, которые не соответствуют рекомендованным значениям, выставляются меньшие баллы (от 1 до 4) в соответствии с заданными ограничениями.

На втором этапе необходимо произвести расчет показателей КСО градообразующего предприятия, используя различные коэффициенты, характеризующие социальную ответственность, рассмотренные в таблице 8.

По нашему мнению, самым приемлемым для расчета показателей КСО является метод балльной оценки, в рамках которого необходимо оценить каждый показатель по пятибалльной шкале на основании матрицы группировки исходных данных для сравнения (табл. 12). 
Балльная оценка состояния КСО рассматриваемых градообразующих предприятий, баллы

\begin{tabular}{|c|c|c|c|c|c|c|c|c|}
\hline \multirow{2}{*}{$\begin{array}{c}\text { Показа- } \\
\text { тель }\end{array}$} & \multicolumn{4}{|c|}{ Предприятие 1 } & \multicolumn{4}{|c|}{ Предприятие 2 } \\
\cline { 2 - 9 } & $\begin{array}{c}\text { Год } \\
\text { Год }\end{array}$ & $\begin{array}{c}\text { Год } \\
3\end{array}$ & $\begin{array}{c}\text { Суммар- } \\
\text { ный балл }\end{array}$ & $\begin{array}{c}\text { Год } \\
1\end{array}$ & $\begin{array}{c}\text { Год } \\
2\end{array}$ & $\begin{array}{c}\text { Год } \\
3\end{array}$ & $\begin{array}{c}\text { Суммар- } \\
\text { ный балл }\end{array}$ \\
\hline 1 & & & & & & & & \\
\hline 2 & & & & & & & & \\
\hline
\end{tabular}

На третьем этапе в рамках системы координат сопоставляются рассматриваемые предприятия по заявленным характеристикам. На каждой оси с использованием определенного масштаба измерения необходимо отметить координаты, которые соответствуют величине критерия. Ломаная линия, проходящая через них, образует многоугольник. Более совершенный графический метод - график-радар, на котором изображаются сразу два многоугольника по исследуемым предприятиям.

Радар оценки корпоративной социальной ответственности градообразующих предприятий строится по следующим правилам [61, с. 62]:

- круг радара делится радиальными шкалами оценки на равные сектора, число которых равно числу показателей;

- шкалы на радиальных прямых градируются так, чтобы все значения показателей лежали внутри оценочного круга;

- значение показателя улучшается по мере удаленности от центра круга;

- для сравнения предприятий их радары строятся на одном круге.

Данный метод позволяет определить совокупный показатель социальной политики для каждого предприятия по формуле [61, с. 62]: 


$$
I=\frac{S_{p}}{S}
$$

где $\mathrm{Sp}$ - площадь радара (многоугольника);

$\mathrm{S}$ - площадь оценочного круга.

Значением площади оценочного круга $\mathrm{S}$ в данном примере является радар эталонного предприятия, которому присущи максимальные значения по всем рассматриваемым показателям. Данный метод построения радара является наглядным, а также дает объективную оценку ведения социально направленного бизнеса анализируемых градообразующих предприятий. Пример построения графика-радара по двум условным градообразующим предприятиям (по 12 выбранным критериям, характеризующим корпоративную социальную ответственность предприятий) представлен на рисунке 16.

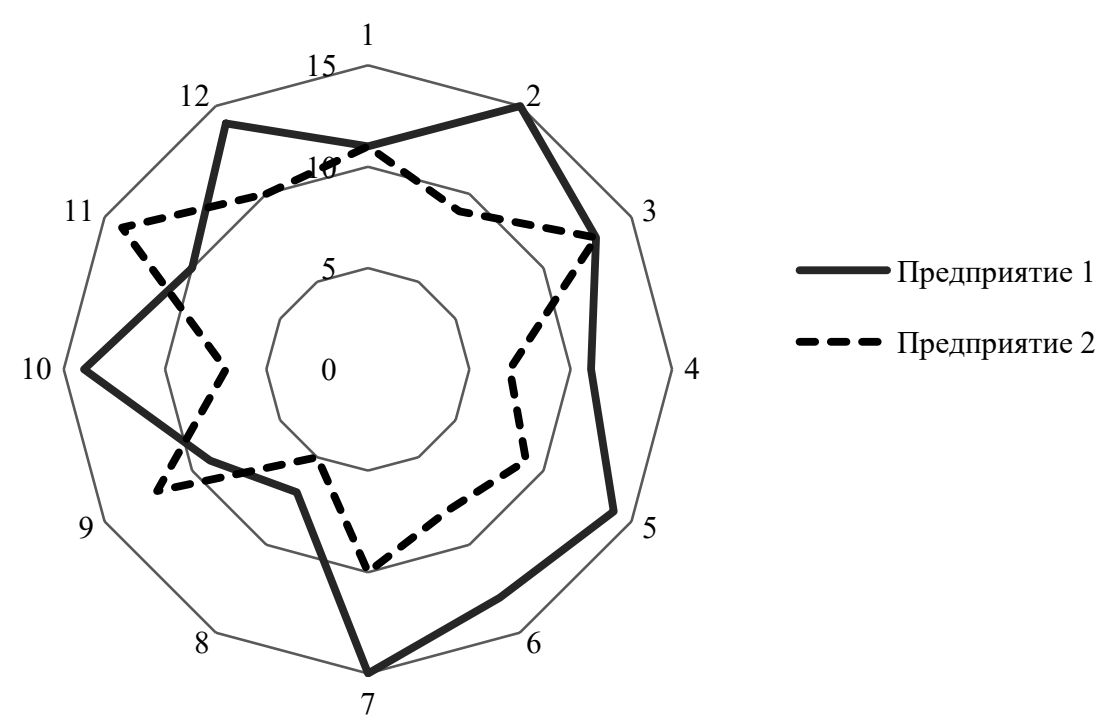

Рисунок 16. Графики-радары корпоративной социальной ответственности двух условных предприятий на оценочном круге

Далее необходимо рассчитать площадь каждого многоугольника. Пусть $\left\{\mathrm{x}_{\mathrm{i}}\right\}, \mathrm{i}=1,2, \ldots, \mathrm{n}$ - последовательность координат соседних друг другу вершин многоугольника без самопересечений. Таким 
образом, площади фигур вычисляются по формуле вычисления площади равноугольного многоугольника:

$$
S=\sum_{i=1}^{n}\left(\frac{1}{2} \sin \alpha \times x_{i} \times x_{i+1}\right),
$$

где $\mathrm{n}$ - количество рассматриваемых показателей;

$\alpha$ - угол между двумя показателями на графике-радаре;

$\mathrm{x}_{\mathrm{i}}-$ значение i-го показателя.

Затем площади радаров социальной ответственности исследуемых градообразующих предприятий сравниваются с эталонным значением. При этом площадь всего оценочного круга определяется по известной формуле вычисления площади круга:

$$
S=\pi R^{2},
$$

где $\mathrm{R}$ - радиус оценочного круга, т.е. максимально возможное значение каждого показателя.

Таким образом, длина радиуса оценочного круга 15 единиц, на основании того, что это максимально возможное количество баллов по каждому рассматриваемому показателю, выставленных эталонному предприятию. Из этого следует, что площадь оценочного круга (по показателям КСО эталонного предприятия) составляет 706,86 квадратных единиц.

Для проведения четвертого этапа оценки состояния корпоративной социальной ответственности организаций в моногородах нами предлагается провести анализ полученных результатов. Результаты 
основываются на сравнении площадей многоугольников предприятий с площадью оценочного круга по формуле (9).

Таким образом, по нашему мнению, построение такого графика дает наглядное представление и зрительную оценку, как выглядит обобщенный критерий корпоративной социальной ответственности каждого градообразующего предприятия. При этом преимуществом метода является то, что он комплексный и учитывает наибольшее количество факторов, которые влияют на КСО предприятия. Также многоугольник корпоративной социальной ответственности градообразующих предприятий, созданный на основе графического соединения оценок положения предприятия по наиболее значимым социальным направлениям его деятельности, позволяет сравнить возможности таких организаций. И разделяя точку зрения В.Н. Шитова, О.Ф. Цымбалиста, можно отметить, что при построении радаров на одном оценочном круге можно выявить слабые и сильные стороны предприятий относительно друг друга [61, с. 63].

Из этого следует, что проведение многомерного рейтингового анализа позволяет сделать вывод, что принадлежность предприятия территориальному местоположению и социально-экономическая ситуация муниципального образования, в котором предприятие осуществляет свою деятельность, оказывают существенное влияние не только на уровень социальной политики, но и на выбор направлений социальных инвестиций.

Для развития корпоративной социальной ответственности в моногородах после проведения оценки социально-экономических показателей градообразующего предприятия нами предлагается применять один из часто используемых инструментов КСО - социальное проектирование, с последующей оценкой его экономической эффективности. 


\section{2. Социальное проектирование как методический}

инструментарий развития корпоративной социальной ответственности промышленных предприятий в моногородах

После проведения оценки состояния КСО промышленного градообразующего предприятия с помощью многомерного рейтингового анализа и определения необходимых направлений социального инвестирования в качестве второго этапа разработки методического инструментария предлагается осуществление социального проектирования для развития корпоративной социальной ответственности промышленных предприятий в моногородах.

Социальное проектирование ориентировано на улучшение условий взаимодействия экономических субъектов для осуществления задач, направленных на развитие социального и человеческого капитала. С нашей точки зрения, социальное проектирование градообразующих предприятий имеет прямое отношение к развитию социальной сферы в моногороде, а также решению различных социально-экономических проблем и к социальной ответственности самого бизнеса.

В разной литературе существует множество определений понятия «социальный проект». По мнению В.А. Лукова, социальный проект - инструмент социальных изменений, основывающийся на природном человеческом свойстве конструировать реальность [62].

М. Смехов и О. Солдатова считают, что социальный проект - это инструмент для решения социально значимых вопросов определенного сообщества [63].

Д. Воробьев под социальным проектом подразумевает материальные, технологические, управленческие, добровольческие или иные ресурсы, а также финансовые средства, используемые, как правило, из части прибыли компаний и направляемые по решению руководства на реализацию социальных программ, разработанных с учетом интересов основных внутренних и внешних заинтересованных 
сторон (стейкхолдеров) в предположении, что в стратегическом (реже - тактическом) отношении компанией будет получен социальный или экономический эффект (польза) [64].

Исходя из данного определения, можно сделать вывод, что при реализации социального проекта, прежде всего, достигается нефинансовый эффект - социальный, экологический, организационный, маркетинговый и так далее. При этом достижение финансовых целей при реализации социального проекта также возможно, но оно не является основной его задачей.

Таким образом, резюмируя вышеперечисленные точки зрения, можно сделать вывод, что социальный проект - это проект некоммерческого характера, содержащий комплекс мероприятий, направленных на решение и (или) смягчение существующих социальных проблем и достижение конкретных результатов.

Любой социальный проект имеет определенный жизненный цикл. Жизненный цикл, по мнению В.А. Лукова, составляет временной период между моментом создания проекта и моментом его ликвидации [62, с. 64]. При этом жизненный цикл состоит из этапов проектирования (системы правил, приемов, методов, операций и процедур создания и осуществления социального проекта) [65, с. 21].

В качестве основных этапов применительно к данному исследованию рассматриваются следующие [62, с. 64]:

1-й этап: разработка концепции проекта. Как правило, в концепции отражают: актуальность проекта, его цель и задачи, содержание предполагаемой деятельности, финансовое и организационное обоснование проекта, ожидаемые последствия его осуществления.

2-й этап: оценка жизнеспособности проекта. Для данного этапа основными инструментами оценки являются социальное прогнозирование и социальная диагностика, а также методы экспертных оценок 
[62, с. 71]. Основной задачей данного этапа является установление степени риска при реализации проекта.

3-й этап: планирование проекта (устанавливается перечень и порядок мероприятий реализации социального проекта). На данном этапе отбираются мероприятия в соответствии с поставленными задачами, работы сопоставляются с ресурсами, устанавливаются сроки и ответственные исполнители, определяются объемы финансирования, фиксируются контрольные стадии и конечные результаты [62, с. 85]. Самым простым способов составления такого плана является построение таблицы (табл. 13).

Таблица 13

\section{Пример составления плана социального проекта}

\begin{tabular}{|c|c|c|c|c|}
\hline $\begin{array}{c}\text { № } \\
\text { п/п }\end{array}$ & $\begin{array}{c}\text { Содержа- } \\
\text { ние } \\
\text { мероприя- } \\
\text { тий }\end{array}$ & $\begin{array}{c}\text { Ответственные } \\
\text { за } \\
\text { исполнение }\end{array}$ & $\begin{array}{c}\text { Финансовое обеспече- } \\
\text { ние }\end{array}$ & $\begin{array}{c}\text { Сроки } \\
\text { исполнения }\end{array}$ \\
\hline & & & & \\
\hline
\end{tabular}

4-й этап: составление бюджета. Для реализации проекта необходимо определить, сколько и какие ресурсы требуются. Ресурсы подразделяются на финансовые, человеческие, материально-технические. Особое внимание при составлении бюджета необходимо уделить целям и объему финансирования, а также предполагаемому экономическому и социальному эффекту от осуществления мероприятий.

5-й этап: защита проекта, которая представляет собой особую стадию принятия управленческих решений о реализации разработанного социального проекта, его финансовой и прочей поддержке.

6-й этап: предварительный контроль, осуществляемый до фактического начала работ. Назначение такого контроля - проверка проекта обеспеченностью финансовыми, материально-техническими и человеческими ресурсами. 
7-й этап: реализация проекта (выполнение запланированных мероприятий).

8-й этап: коррекция проекта по итогам мониторинга, который является основной частью комплексной оценки социального проекта, предоставляющей объективную и полную информацию о результатах реализации социального проекта и его эффективности [66, с. 363]. Мониторинг проекта проводится с целью регистрации динамических изменений социального проекта и окружающей среды под влиянием его воздействия, а также для контроля сроков выполнения проектов и повышения ответственности исполнителей за достижение планируемых результатов [67, с. 133]. Основные этапы проведения мониторинга социальных проектов в обобщенном виде представлены на $р u$ сунке 17 [66, с. 365].

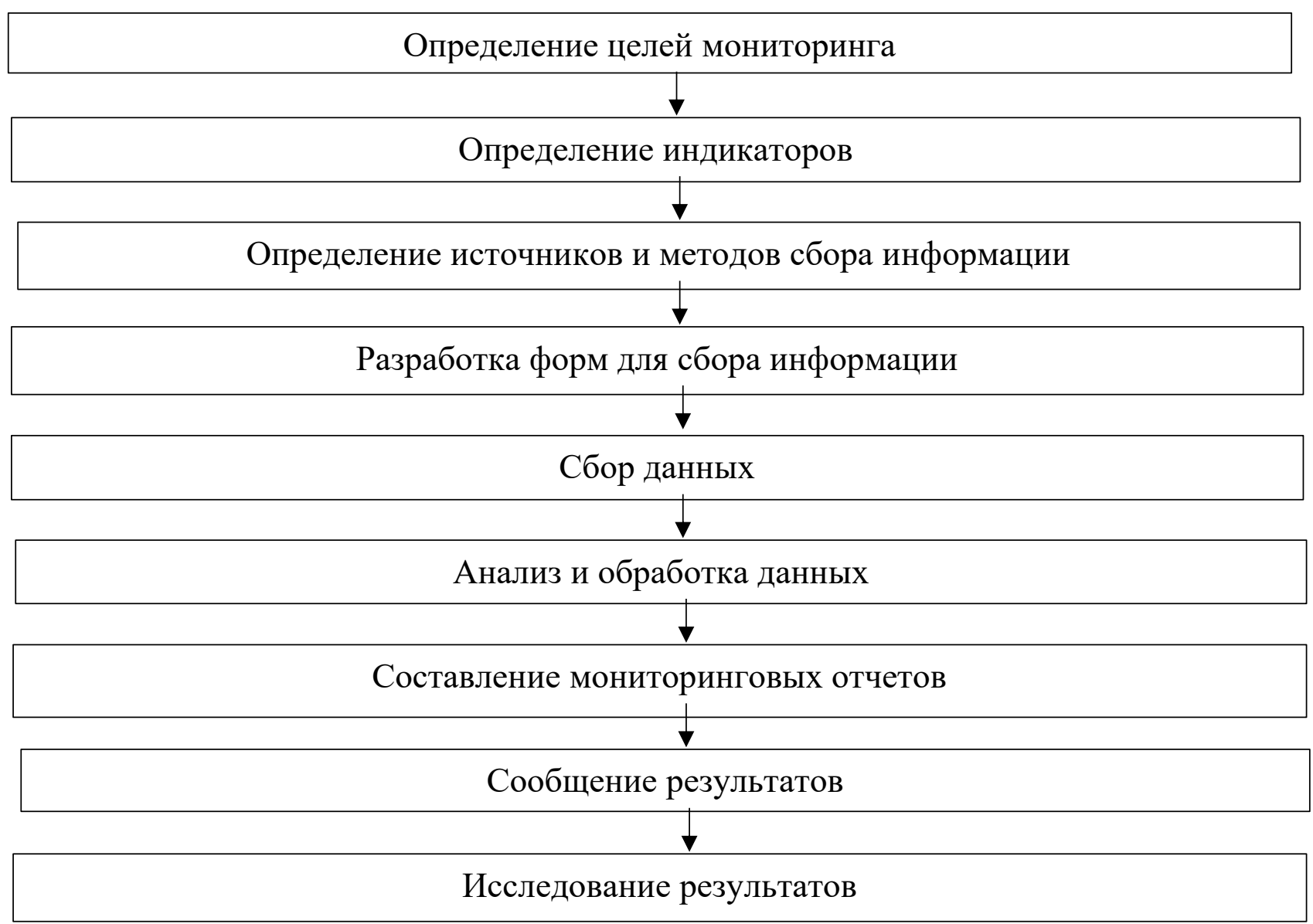

Рисунок 17. Основные этапы проведения мониторинга социальных проектов 
9-й этап: завершение работ и ликвидация проекта. Эта стадия предусматривает оценку реализации социального проекта и позволяет зафиксировать завершение его работы. Заключительная оценка представляет собой процесс сбора информации для:

1) оценки достигнутых результатов;

2) объяснения того, посредством чего получены результаты;

3) лучшего планирования будущих проектов.

Наибольшее значение и распространение имеют проекты и программы внешних социальных инвестиций в моногородах. Проводятся они, соответственно, градообразующими предприятиями в основном на дополнительные средства, кроме налоговых платежей в региональные, местные бюджеты. С учетом того, что на градообразующих предприятиях работает большинство социально активного населения территорий присутствия крупных организаций, фактически происходит объединение внутренней и внешней социальной политики данных предприятий [68, с. 320].

Несмотря на существенные различия между типами социальных проектов и многообразием условий их реализации, оценка их эффективности и экспертиза должны производиться в определенном смысле единообразно, на основе единых обоснованных принципов $[69$, с. 36]. Методические рекомендации по оценке эффективности инвестиционных проектов в основу определения эффективности проектов закладывают ряд методологических принципов, применимых к любым типам проектов, независимо от их технических, технологических, финансовых, отраслевых или региональных особенностей (puc. 18) [69, с. 36]. 


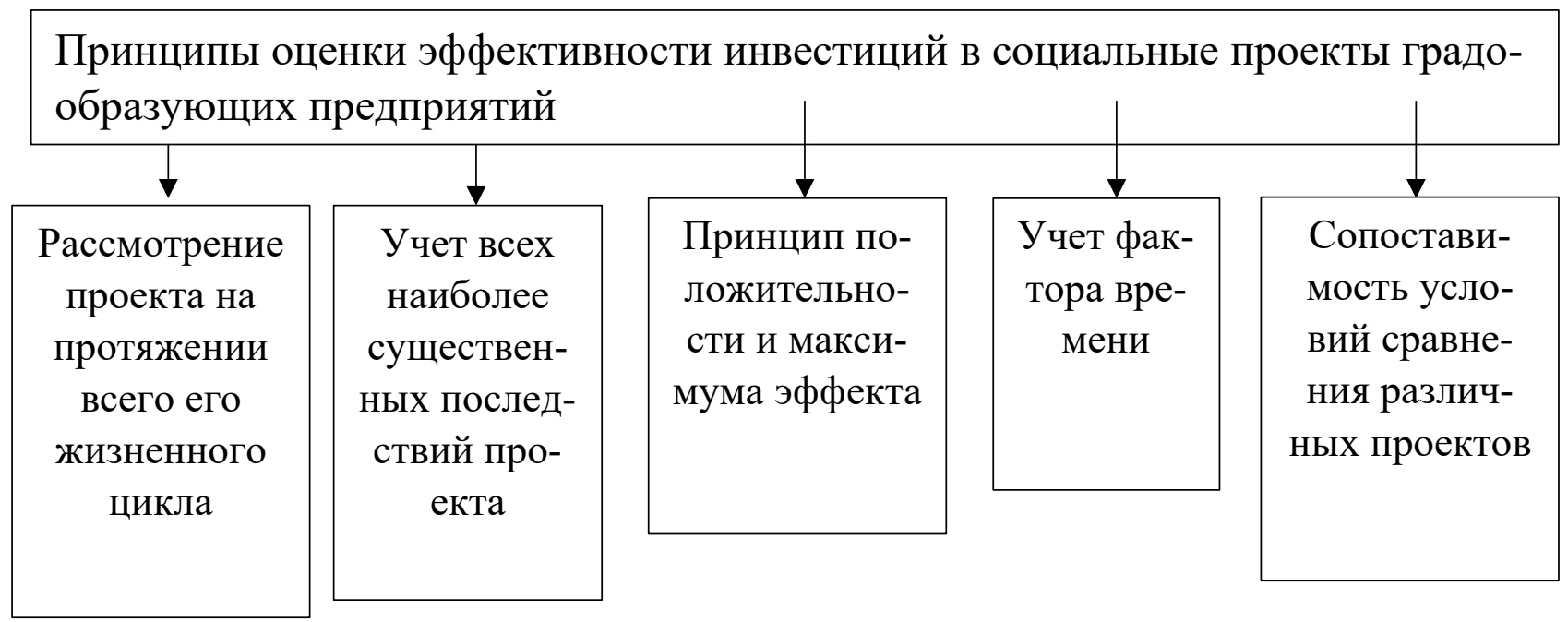

Рисунок 18. Методические принципы оценки эффективности инвестиций в социальные проекты градообразующих предприятий

Для оценки эффективности целесообразно выделить следующие этапы управления социальным проектом [70, с. 48]:

- постановка цели реализации социального проекта. Проект, с одной стороны, может иметь несколько целей, с другой, может иметь сопутствующие благоприятные и неблагоприятные эффекты;

- определение конкретных мероприятий, необходимых для достижения поставленных целей. Этот этап во многом определяет эффективность всего социального проекта, так как на нем выбираются технологии реализации проекта, минимизация издержек на их достижение;

- определение результатов реализации социального проекта. Этот этап необходим для оценки и анализа эффектов от реализации проекта и используется для управления проектом;

- принятие решения об эффективности реализации проекта. Для этого используются инструментарий сопоставления результатов реализации проекта и понесенных ресурсных затрат. 
Оценка социальных проектов исключительно по экономическим показателям малоэффективна, так как в них также входят социальные показатели.

Оценка эффективности вложений в социальный проект подразумевает обоснование необходимости и целесообразности его реализации. Целесообразность проекта и его соответствие приоритетам социально-экономического развития региона подтверждается на предварительном этапе оценки уровня качества обеспеченности населения бюджетными услугами, прогнозом изменения спроса и стоимости соответствующих услуг.

Далее производится оценка совокупной эффективности реализации инвестиционного проекта, которая представлена системой показателей (рис. 19) [69, с. 40].

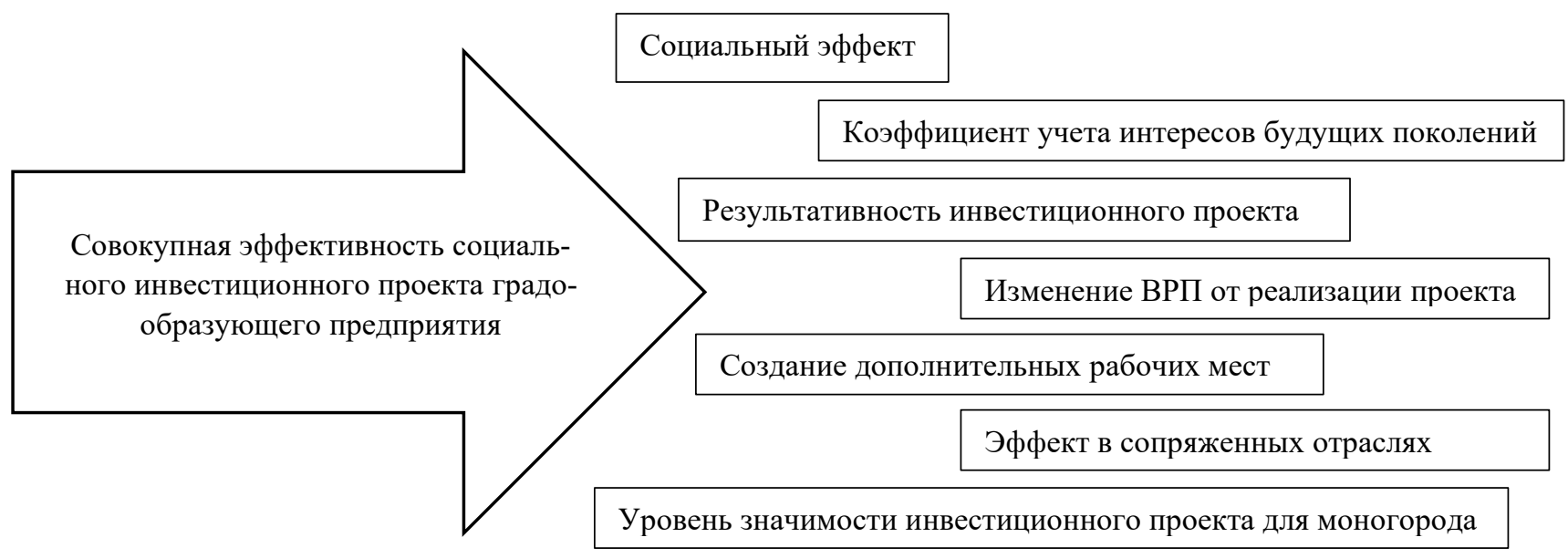

Рисунок 19. Показатели совокупной эффективности инвестиций в социальные проекты градообразующих предприятий [69, с. 40]

Эффективность социальных проектов проявляется в возможности достижения положительных и избежания отрицательных изменений на предприятии с социальной точки зрения. Рассматривая внутренние направления реализации корпоративной социальной ответственности, в первую очередь необходимо определить влияние таких 
проектов на персонал градообразующего предприятия. К числу положительных изменений можно отнести следующие:

- обеспечение персоналу надлежащего уровня качества жизни (достойная заработная плата, благоприятные условия труда, повышение квалификации кадров, социальное обеспечение и др.);

- достижение степени свободы и самостоятельности (возможность принятия самостоятельных решений, установление графика и интенсивности работы и др.);

- создание условий для развития и реализации индивидуальных способностей работников;

- создание благоприятного социально-психологического климата.

К числу устраняемых отрицательных изменений можно отнести:

- ущерб, наносимый персонально (физические и интеллектуальные перегрузки, стрессовые ситуации и др.);

- ущерб, наносимый здоровью персонала неблагоприятными условиями труда (несчастные случаи, профзаболевания и др.).

Также для оценки эффективности социального проектирования необходимо определить уровень значимости проекта. По уровню значимости социальные проекты делятся на четыре уровня. Наибольший приоритет отдают инвестиционным проектам первого уровня значимости. Коэффициенты уровня значимости и эффективность социального проекта определяются в результате экспертной оценки на основе системы индикаторов. Эффект от социального проекта в сопряженных отраслях рассчитывается по формуле [69, с. 40]:

$$
M \ni=\frac{\sum K \Pi \times H H}{\sum B \Pi}
$$

где МЭ - мультипликативный эффект от реализации социального проекта в сопряженных отраслях; 
КП - сумма по контрактам с задействованными подрядными организациями в реализации социального проекта и зарегистрированными на территории моногорода;

НН - показатель средней налоговой нагрузки (объем налоговых изъятий из выручки градообразующего предприятия);

ВП - величина государственной финансовой поддержки, предоставляемой инициатору социального инвестиционного проекта.

В результате реализации социального проекта расчет прироста валового регионального продукта производится по следующей формуле [69, с. 40]:

$$
\ni_{B P \Pi}=4 H \times \triangle B P \Pi \times \Pi \Pi \Pi,(13)
$$

где Эврп - эффект, вызванный приростом валового регионального продукта, тыс. руб.;

ЧН - численность населения, качество жизни которого улучшается в результате реализации социального проекта;

$\Delta$ ВРП - прирост валового регионального продукта на душу населения, по прогнозным оценкам на расчетный год реализации проекта, тыс. руб.;

ППП - прогнозный показатель прироста валового внутреннего продукта за счет реализации социальных мероприятий (на каждый пункт прироста ВВП соответственно).

Под социальным эффектом инвестиционного проектирования в КСО градообразующего предприятия понимаются значимые для населения моногорода последствия его реализации. Эффект социального проектирования представлен в виде суммарного балльного индикатора и рассчитывается по формуле [69, с. 41]: 


$$
\mathrm{C} \ni=\sum_{i=1}^{n} И
$$

где СЭ - эффект от реализации социального проекта;

И - индикатор, учитывающий увеличение і-го показателя по рассматриваемому направлению, который определяется в баллах на основе результатов экспертной оценки.

Также после реализации социального проекта градообразующим предприятием необходимо произвести расчет его экономической эффективности. Для данного расчета оцениваются следующие показатели: динамика производительности труда, изменение количества простоев оборудования, изменение объема выпуска продукции, изменение выручки и других видов прибыли.

Таким образом, социальное проектирование является наиболее подходящим инструментом для развития корпоративной социальной ответственности промышленных предприятий в моногородах.

Резюмируя все вышесказанное, основные этапы разработанной методики развития корпоративной социальной ответственности промышленных предприятий моногородов можно представить схематично в виде алгоритма (рис. 20).

Таким образом, применяя разработанный инструментарий развития корпоративной социальной ответственности промышленных предприятий в моногородах, градообразующие предприятия смогут проводить самоанализ, оценивая социально-экономические показатели деятельности для дальнейшего выбора направлений социального проектирования и инвестирования в КСО. Все это положительно повлияет на финансово-хозяйственную деятельность предприятия, его конкурентоспособность и инвестиционную привлекательность самого градообразующего предприятия и моногорода в целом. 
1. Оценка корпоративной социальной ответственности градообразующего предприятия

1.1 Выбор и обоснование системы коэффициентов для оценки КСО, сбор данных по выбранным показателям и формирование матрицы исходных данных

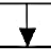

1.2 Расчет показателей КСО градообразующего предприятия по выбранным коэффициентам, используя метод балльной оценки

1.3 Построение графика-радара КСО предприятия по рассчитанным показателям и расчет площади многоугольника КСО предприятия по формуле: $S=\sum_{i=1}^{n} \frac{1}{2} \sin \alpha \times x_{i} \times x_{i+1}$

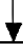

1.4 Анализ полученных результатов и сравнение площади многоугольника КСО предприятия с площадью оценочного круга. Определение недостатков системы КСО предприятия для последующего направления инвестиций

\section{2. Социальное проектирование по выявленным недостаткам системы КСО предприятия}

2.1 Разработка концепции проекта (определение актуальности проекта, цели и задач, содержание предполагаемой деятельности, финансовое и организационное обоснование, ожидаемые последствия)

\begin{tabular}{l}
2.2 Оценка жизнеспособности проекта (социальное прогнозирование и диагностика) \\
2.3 Планирование проекта (установление перечня и порядка мероприятий реализации проекта) \\
\hline $\begin{array}{l}2.4 \text { Составление бюджета (определение необходимого объема финансовых, } \\
\text { материально-технических и человеческих ресурсов) }\end{array}$ \\
2.5 Защита проекта и принятие управленческих решений \\
2.6 Предварительный контроль, осуществляемый до фактического начала работ \\
\hline 2.8 Коррекция проекта по итогам мониторинга \\
2.9 Завершение работ, ликвидация проекта и его оценка \\
\hline
\end{tabular}

Оценка экономической эффективности использования инструментария развития КСО промышленного предприятием в моногороде

Рисунок 20. Основные этапы методики развития корпоративной социальной ответственности промышленных предприятий в моногородах 


\section{3. Апробация разработанного инструментария развития корпоративной социальной ответственности и расчет экономической эффективности его внедрения}

В качестве апробации предлагаемого инструментария развития корпоративной социальной ответственности в моногородах выбрано градообразующее предприятие АО «Корпорация ВСМПОАВИСМА» Верхнесалдинского городского округа, который относится к монопрофильному муниципальному образованию со стабильной социально-экономической ситуацией.

Публичное акционерное общество «Корпорация ВСМПОАВИСМА» (далее - Корпорация, «ВСМПО-АВИСМА») образовано согласно Гражданскому кодексу РФ и Федеральному закону от 26.12.1995 № 208-Ф3 «Об акционерных обществах» [71, 72]. Место нахождения предприятия: Российская Федерация, Свердловская область, г. Верхняя Салда, ул. Парковая 1. АО «Корпорация ВСМПОАВИСМА» имеет филиал «АВИСМА», расположенный в г. Березники, Пермский край.

АО «Корпорация ВСМПО-АВИСМА» - крупнейший в мире производитель титана, имеющий полный технологический цикл: от переработки сырья до выпуска готовых изделий с высокой степенью механической обработки [35]. Основным направлением деятельности Корпорации является производство титановой продукции: слитки, биллеты, слябы, крупные штампованные поковки дисков и лопаток авиационных двигателей, раскатные кольца, профили, бесшовные и сварные трубы и другие изделия. Алюминиевый дивизион включает в себя производство слитков, прессованных профилей, панелей, труб, а также холоднодеформированных труб и труб для атомной промышленности. Кроме того, Корпорация производит ферротитан, один из самых распространенных ферросплавов. Корпо- 
рация поставляет продукцию на рынки 50 стран, глубоко интегрирована в мировую авиакосмическую индустрию и является для многих компаний стратегическим поставщиком. Также Корпорация является промышленным градообразующим предприятием моногорода Верхняя Салда.

Корпоративное управление АО «Корпорация ВСМПОАВИСМА» направлено на создание и сохранение доверительных отношений Корпорации с инвесторами, защиту прав и интересов внешних и внутренних стейкхолдеров, а также увеличение стоимости акций. Система корпоративного управления на предприятии создана в соответствии с требованиями законодательства и с учетом современных практик ведущих российских и зарубежных компаний.

АО «Корпорация ВСМПО-АВИСМА» - градообразующее предприятие, которое, следуя принципам социальной ответственности, реализует социальную политику, направленную на эффективное взаимодействие с персоналом, с целью его привлечения, удержания и мотивации к производительному труду. Корпоративная социальная политика направлена на обеспечение социальной поддержки через систему гарантий, компенсаций и льгот, предоставляемых работникам, членам их семей и неработающим пенсионерам. Основным инструментом реализации социальной политики предприятия является Коллективный договор, который содержит нормы о предоставлении работникам корпоративного социального пакета (КСП) (Приложение А).

В уставе предприятия также отмечается, что социальная ответственность Корпорации заключается в своевременной и полной уплате налогов и сборов, поддержании достойного уровня заработной платы для работников, соблюдении принципов социального партнерства, установлении гарантий и компенсаций для работников путем заключения коллективного договора. Размеры социальных выплат ежегодно устанавливаются Совместным приказом-постановлением работодателя, профсоюзных комитетов ВСМПО и АВИСМА. В 2018 году 
размер корпоративного социального пакета в среднем на 1 работника Корпорации составил 68 тыс. руб. [58].

Поскольку Корпорация является социально ориентированным предприятием, в 2018 году объем средств, направленных на выполнение его социальных обязательств, составил 1740 млн руб. [58]. Кроме того, компания уделяет большое внимание защите окружающей среды, принимает на себя обязательства в сфере промышленной безопасности.

Следуя принципам Экологической политики, в АО «Корпорация ВСМПО-АВИСМА» созданы условия и принимаются необходимые меры для защиты окружающей среды посредством [35]:

- систематического обучения персонала в области экологии, повышения его экологической сознательности и компетентности;

- соблюдения персоналом экологических требований при производственной деятельности;

- проведения мероприятий, позволяющих снизить или сохранить на допустимом уровне негативное воздействие экологических аспектов, образующихся в результате деятельности Общества;

- снижения риска возникновения аварийных ситуаций и их негативного воздействия на окружающую среду;

- открытого сотрудничества в области охраны окружающей среды с заинтересованными организациями и общественностью;

- рационального использования электроэнергии, воды, природного газа и отходов производства.

Информация о деятельности Корпорации в рамках корпоративной социальной ответственности содержит экологические и социальные аспекты, раскрытие которой осуществляется в годовом отчете по результатам работы промышленного предприятия за каждый год. 
Для апробации разработанного инструментария на «ВСМПОАВИСМА» проведена оценка экономических показателей, характеризующих те аспекты деятельности предприятия, которые имеют существенное значение для корпоративной социальной ответственности градообразующих предприятий, для последующего выбора направлений социального проектирования (параграфы 3.1, 3.2).

После предположительного внедрения разработанного инструментария развития КСО промышленных предприятий в моногородах будет проведен расчет экономической эффективности его условного использования. Для данного расчета будут оценены следующие показатели: производительность труда, изменение количества простоев оборудования, изменение объема выпуска продукции, изменение выручки и других видов прибыли.

Для оценки состояния корпоративной социальной ответственности «ВСМПО-АВИСМА» использован метод многомерного рейтингового анализа, представленный в параграфе 3.1.

На начальном этапе обозначена система коэффициентов, характеризующих именно те аспекты деятельности предприятия, которые имеют существенное значение для КСО Корпорации и соответствуют всем необходимым параметрам социальной ответственности бизнеса в монопрофильных городах. А также собраны данные по этим показателям и произведен расчет коэффициентов, по показателям которых проставлены баллы с учетом их соответствия той или иной оценочной категории в течение трех лет (2016-2018 гг.).

Для расчетов коэффициентов в качестве эталонного предприятия выбрано ПАО «Северсталь», поскольку оно общепризнанно является самым социально ориентированным градообразующим предприятием в РФ. Составим таблицу показателей комплексной оценки корпоративной социальной ответственности АО «Корпорация ВСМПОАВИСМА» (табл. 14). 
Показатели корпоративной социальной ответственности АО «Корпорация «ВСМПО-АВИСМА» за 2016-2018 гг.

\begin{tabular}{|c|c|c|c|c|}
\hline № п/п & Показатель & 2016 & 2017 & 2018 \\
\hline 1 & $\begin{array}{l}\text { Коэффициент повышения квалификации } \\
\text { кадров }\end{array}$ & 0,90 & 0,75 & 0,85 \\
\hline 2 & $\begin{array}{l}\text { Коэффициент использования } \\
\text { по квалификации }\end{array}$ & 0,90 & 1,0 & 1,0 \\
\hline 3 & $\begin{array}{l}\text { Коэффициент соотношения среднемесяч- } \\
\text { ной заработной платы работников градооб- } \\
\text { разующего предприятия и в регионе }\end{array}$ & 0,75 & 0,85 & 0,90 \\
\hline 4 & $\begin{array}{l}\text { Коэффициент технологической модерниза- } \\
\text { ции производства }\end{array}$ & 0,90 & 0,95 & 1,0 \\
\hline 5 & Коэффициент стабильности кадров & 0,80 & 0,70 & 0,60 \\
\hline 6 & $\begin{array}{l}\text { Коэффициент условий производственного } \\
\text { быта и повышения безопасности условий } \\
\text { труда работников градообразующего пред- } \\
\text { приятия }\end{array}$ & 0,90 & 0,90 & 0,95 \\
\hline 7 & $\begin{array}{l}\text { Коэффициент обеспеченности санитарно- } \\
\text { бытовыми помещениями }\end{array}$ & 1,0 & 1,0 & 1,0 \\
\hline 8 & $\begin{array}{l}\text { Коэффициент обеспеченности спортив- } \\
\text { ными сооружениями культурно-просвети- } \\
\text { тельскими учреждениями }\end{array}$ & 0,80 & 0,85 & 0,85 \\
\hline 9 & $\begin{array}{l}\text { Коэффициент обеспеченности лечебно- } \\
\text { оздоровительными учреждениями }\end{array}$ & 0,75 & 0,70 & 0,75 \\
\hline 10 & $\begin{array}{l}\text { Коэффициент обеспеченности детскими } \\
\text { учреждениями в моногороде }\end{array}$ & 0,85 & 0,90 & 1,0 \\
\hline 11 & $\begin{array}{l}\text { Коэффициент обеспеченности жильем со- } \\
\text { трудников и населения моногорода }\end{array}$ & 0,45 & 0,50 & 0,60 \\
\hline 12 & $\begin{array}{l}\text { Коэффициент благоустройства территории } \\
\text { монопрофильного муниципального обра- } \\
\text { зования }\end{array}$ & 0,90 & 0,90 & 0,95 \\
\hline
\end{tabular}

Далее оценим каждый показатель по пятибалльной шкале на основании матрицы группировки исходных данных для сравнения (табл. 15). 
Таблица 15

\section{Матрица группировки исходных данных оценки показателей КСО градообразующих предприятий}

\begin{tabular}{|c|c|c|c|c|c|c|}
\hline \multirow{2}{*}{ № п/п } & \multirow{2}{*}{ Показатель } & \multicolumn{5}{|c|}{$\begin{array}{c}\text { Соответствие значения показателя итого- } \\
\text { вому баллу }\end{array}$} \\
\hline & & 1 балл & $\begin{array}{c}2 \\
\text { балла } \\
\end{array}$ & $\begin{array}{c}3 \\
\text { балла } \\
\end{array}$ & 4 балла & $\begin{array}{c}5 \text { бал- } \\
\text { лов }\end{array}$ \\
\hline 1 & $\begin{array}{l}\text { Коэффициент повышения ква- } \\
\text { лификации кадров }\end{array}$ & $\geq 0,20$ & $\geq 0,40$ & $\geq 0,60$ & $\geq 0,80$ & $=1,0$ \\
\hline 2 & $\begin{array}{l}\text { Коэффициент использования } \\
\text { рабочих по квалификации }\end{array}$ & $\geq 0,20$ & $\geq 0,40$ & $\geq 0,60$ & $\geq 0,80$ & $=1,0$ \\
\hline 3 & $\begin{array}{lr}\begin{array}{l}\text { Коэффициент } \\
\text { среднемесячной }\end{array} \\
\text { платы работников градаботнобой } \\
\text { ющего предприятия и в регионе }\end{array}$ & $\geq 0,20$ & $\geq 0,40$ & $\geq 0,60$ & $\geq 0,80$ & $=1,0$ \\
\hline 4 & $\begin{array}{l}\text { Коэффициент технологической } \\
\text { модернизации производства }\end{array}$ & $\geq 0,20$ & $\geq 0,40$ & $\geq 0,60$ & $\geq 0,80$ & $=1,0$ \\
\hline 5 & $\begin{array}{l}\text { Коэффициент стабильности } \\
\text { кадров }\end{array}$ & $\geq 0,40$ & $\geq 0,50$ & $\geq 0,60$ & $\geq 0,70$ & $=0,80$ \\
\hline 6 & $\begin{array}{l}\text { Коэффициент условий произ- } \\
\text { водственного быта и повыше- } \\
\text { ния безопасности условий } \\
\text { труда работников градообразу- } \\
\text { ющего предприятия } \\
\end{array}$ & $\geq 0,20$ & $\geq 0,40$ & $\geq 0,60$ & $\geq 0,80$ & $=1,0$ \\
\hline 7 & $\begin{array}{l}\text { Коэффициент обеспеченности } \\
\text { санитарно-бытовыми помеще- } \\
\text { ниями }\end{array}$ & $\geq 0,20$ & $\geq 0,40$ & $\geq 0,60$ & $\geq 0,80$ & $=1,0$ \\
\hline 8 & $\begin{array}{l}\text { Коэффициент обеспеченности } \\
\text { спортивными } \\
\text { культурно-просветительскимми } \\
\text { учреждениями } \\
\end{array}$ & $\geq 0,20$ & $\geq 0,40$ & $\geq 0,60$ & $\geq 0,80$ & $=1,0$ \\
\hline 9 & $\begin{array}{l}\text { Коэффициент обеспеченности } \\
\text { лечебно-оздоровительными } \\
\text { учреждениями }\end{array}$ & $\geq 0,20$ & $\geq 0,40$ & $\geq 0,60$ & $\geq 0,80$ & $=1,0$ \\
\hline 10 & $\begin{array}{l}\text { Коэффициент обеспеченности } \\
\text { детскими учреждениями в мо- } \\
\text { ногороде }\end{array}$ & $\geq 0,20$ & $\geq 0,40$ & $\geq 0,60$ & $\geq 0,80$ & $=1,0$ \\
\hline 11 & $\begin{array}{l}\text { Коэффициент обеспеченности } \\
\text { жильем сотрудников и населе- } \\
\text { ния моногорода }\end{array}$ & $\geq 0,20$ & $\geq 0,40$ & $\geq 0,60$ & $\geq 0,80$ & $=1,0$ \\
\hline 12 & $\begin{array}{l}\text { Коэффициент благоустройства } \\
\text { территории монопрофильного } \\
\text { муниципального образования }\end{array}$ & $\geq 0,20$ & $\geq 0,40$ & $\geq 0,60$ & $\geq 0,80$ & $=1,0$ \\
\hline
\end{tabular}


Основываясь на матрице, представленной в таблище 12, проведем оценку состояния корпоративной социальной ответственности АО «Корпорация ВСМПО-АВИСМА» за 2016-2018 гг. в баллах (табл. 16).

Таблицุа 16

\section{Балльная оценка состояния КСО рассматриваемого градообразую- щего предприятия АО «Корпорация ВСМПО-АВИСМА»}

В баллах

\begin{tabular}{|c|l|c|c|c|c|}
\hline № п/п & \multicolumn{1}{|c|}{ Показатель } & 2016 & 2017 & 2018 & $\begin{array}{c}\text { Сум- } \\
\text { марный } \\
\text { балл }\end{array}$ \\
\hline 1 & $\begin{array}{l}\text { Коэффициент повышения квалификации } \\
\text { кадров }\end{array}$ & 4 & 3 & 4 & 11 \\
\hline 2 & $\begin{array}{l}\text { Коэффициент использования рабочих } \\
\text { по квалификации }\end{array}$ & 4 & 5 & 5 & 14 \\
\hline 3 & $\begin{array}{l}\text { Коэффициент соотношения среднемесяч- } \\
\text { ной заработной платы работников градооб- } \\
\text { разующего предприятия и в регионе }\end{array}$ & 3 & 4 & 4 & 11 \\
\hline 4 & $\begin{array}{l}\text { Коэффициент технологической модерниза- } \\
\text { ции производства }\end{array}$ & 4 & 4 & 5 & 13 \\
\hline 5 & $\begin{array}{l}\text { Коэффициент стабильности кадров } \\
\text { Коэффициент условий производстенного } \\
\text { быта и повышения безопасности условий } \\
\text { труда работников градообразующего пред- } \\
\text { приятия }\end{array}$ & 5 & 4 & 3 & 12 \\
\hline 7 & $\begin{array}{l}\text { Коэффициент обеспеченности санитарно- } \\
\text { бытовыми помещениями }\end{array}$ & 5 & 5 & 5 & 12 \\
\hline 8 & $\begin{array}{l}\text { Коэффициент обеспеченности спортив- } \\
\text { ными сооружениями культурно-просвети- } \\
\text { тельскими учреждениями }\end{array}$ & 4 & 4 & 4 & 12 \\
\hline 9 & $\begin{array}{l}\text { Коэффициент обеспеченности лечебно- } \\
\text { оздоровительными учреждениями }\end{array}$ & 3 & 3 & 3 & 9 \\
\hline 10 & $\begin{array}{l}\text { Коэффициент обеспеченности детскими } \\
\text { учреждениями в моногороде }\end{array}$ & 4 & 4 & 5 & 13 \\
\hline 11 & $\begin{array}{l}\text { Коэффициент обеспеченности жильем со- } \\
\text { трудников и населения моногорода }\end{array}$ & 2 & 2 & 3 & 7 \\
\hline 12 & $\begin{array}{l}\text { Коэффициент благоустройства территории } \\
\text { монопрофильного муниципального образо- } \\
\text { вания }\end{array}$ & 4 & 4 & 12 \\
\hline
\end{tabular}


Далее в рамках системы координат сопоставим рассматриваемое предприятие по заявленным характеристикам. На каждой оси с использованием определенного масштаба измерения отметим координаты, которые соответствуют величине критерия. График-радар построен на 12 осях, которые соответствуют 12 выбранным показателям, суммарные значения которых представлены в таблице 13. Построим график-радар социальной ответственности для предприятия АО «Корпорация ВСМПО-АВИСМА» (puc. 21).

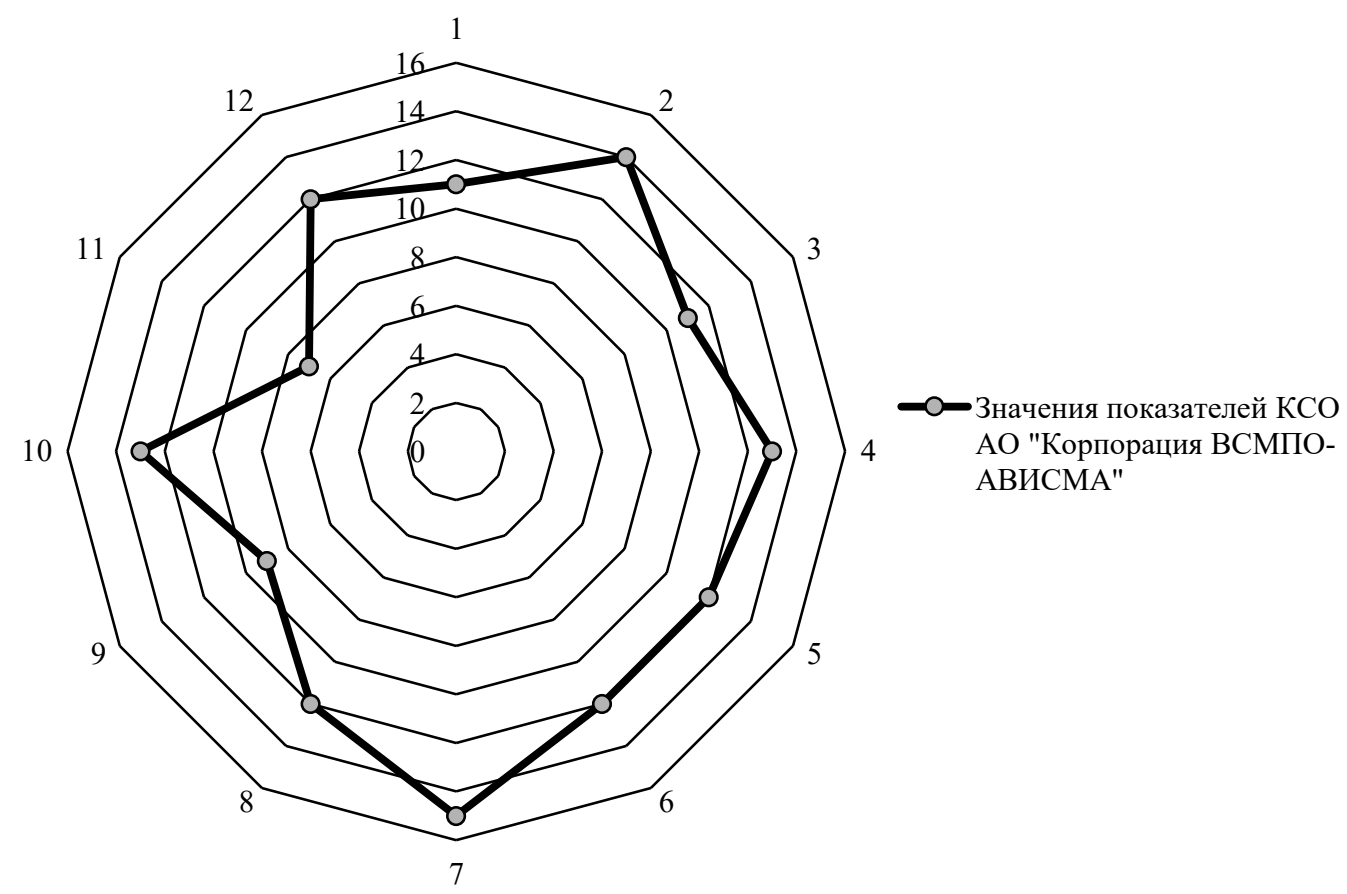

Рисунок 21. График-радар корпоративной социальной ответственности АО «Корпорация ВСМПО-АВИСМА» на оценочном круге

Далее рассчитаем площадь многоугольника КСО рассматриваемого предприятия по формуле (10). Таким образом, площадь радара корпоративной социальной ответственности градообразующего предприятия АО «Корпорация ВСМПО-АВИСМА» равна 410,75 квадратных единиц.

При этом площадь всего оценочного круга определяется по формуле вычисления площади круга (формула (11)). Таким образом, длина радиуса оценочного круга 15 единиц, на основании того, что 
это максимально возможное количество баллов по каждому рассматриваемому показателю, выставленных эталонному предприятию. Из этого следует, что площадь оценочного круга составляет 706,86 квадратных единиц.

Следующий этап оценки состояния корпоративной социальной ответственности организаций в моногородах состоит в анализе полученных результатов. Данный метод позволяет определить совокупный показатель социальной политики для предприятия по формуле (9).

Проведенные расчеты показали, что корпоративная социальная ответственность АО «Корпорация ВСМПО-АВИСМА» значительно ниже эталонных значений, но при этом выше среднего уровня. Данные результаты основаны на сравнении площадей многоугольника рассматриваемого предприятия с площадью оценочного круга по формуле (9):

$$
I_{\text {"ВСмПО-АВИСмА" }}=\frac{410,75}{706,86}=0,58 .
$$

Таким образом, построение такого графика дало наглядное представление и зрительную оценку обобщенного критерия корпоративной социальной ответственности градообразующего предприятия АО «Корпорация ВСМПО-АВИСМА». Также можно отметить, что при построении радара выявлены слабые и сильные стороны предприятия. К слабым сторонам корпоративной социальной ответственности «ВСМПО-АВИСМА» относятся области, суммарный балл которых менее 12:

- повышение квалификации кадров;

- соотношение среднемесячной заработной платы работников градообразующего предприятия и в регионе; 
- обеспеченность жильем сотрудников и населения моногорода;

- обеспеченность лечебно-оздоровительными учреждениями.

Также для выявления настоящего мнения жителей по существующей проблеме на территории г. Верхняя Салда авторами был проведен опрос в виде заполнения онлайн-формы на предмет комфортности проживания в моногороде. Опрос проводился анонимно, все данные сведены в статистический ряд. Опрос пройден 2584 респондентами из всего населения, составляющего 41228 человек (по данным на апрель 2020 года). Результаты онлайн-опроса представлены на $p u-$ сунке 22.

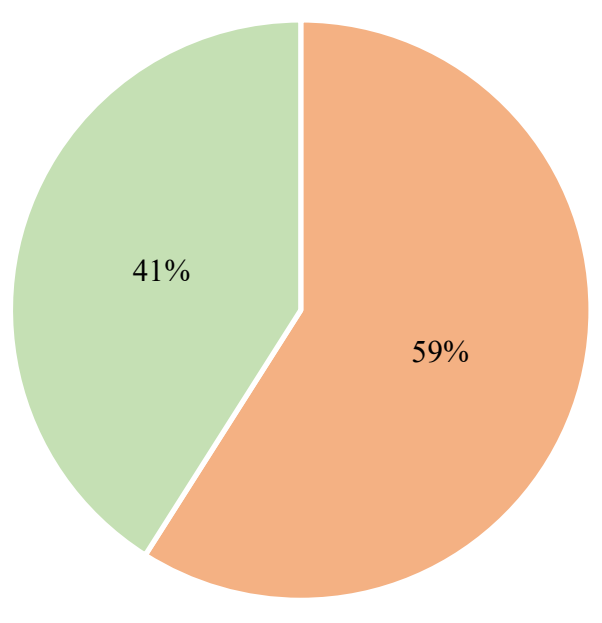

Рисунок 22. Удовлетворенность населения г. Верхняя Салда проживанием в моногороде

При этом на вопрос о смене территории для проживания были получены следующие результаты (рис. 23):

население г. Верхняя Салда, неудовлетворенное уровнем жизни в моногороде

население г. Верхняя Салда, удовлетворенное уровнем жизни в моногороде 


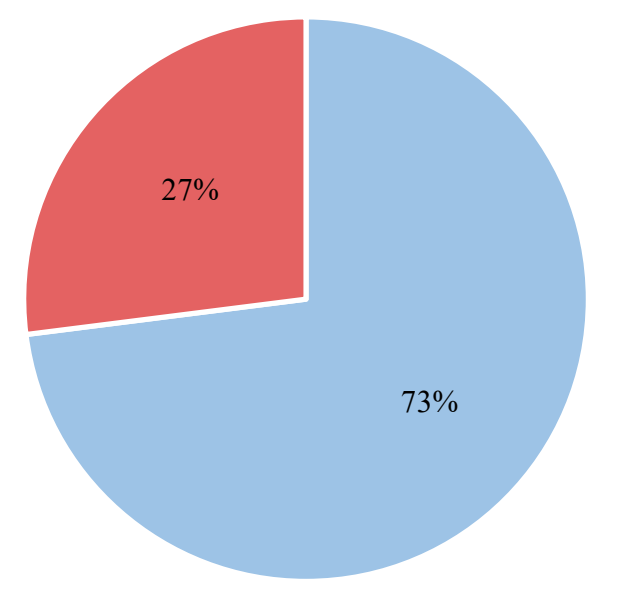

Рисунок 23. Готовность населения г. Верхняя Салда к смене места жительства

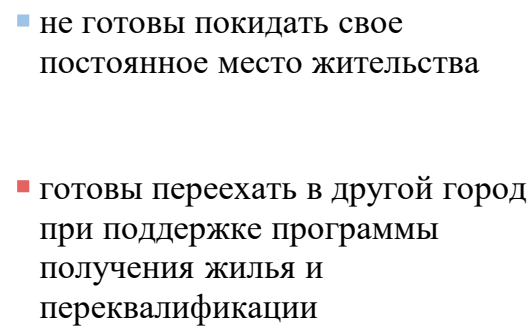

Как видно из проведенного исследования и оценки социальноэкономических показателей АО «Корпорация ВСМПО-АВИСМА», уровень корпоративной социальной ответственности рассматриваемого предприятия находится не на высшем уровне, и выбор направлений социальных инвестиций в корпоративную социальную ответственность АО «Корпорация ВСМПО-АВИСМА» следует делать, основываясь на выявленных слабых областях КСО предприятия, обозначенных выше.

В качестве второго этапа разработанного методического инструментария развития корпоративной социальной ответственности промышленных предприятий в моногородах для апробации необходимо осуществление социального проектирования для развития КСО градообразующего предприятия АО «Корпорация ВСМПО-АВИСМА» по выбранным направлениям. 
Применим рассмотренные основные этапы социального проектирования в рамках разработанного инструментария (параграф 3.2) для создания социального проекта исследуемого предприятия:

1-й этап: разработка общей концепции социальной политики АО «Корпорация ВСМПО-АВИСМА» представлена на рисунке Б.1 (Приложение Б). Концепция содержит ключевые моменты, включая рассмотрение слабых сторон корпоративной социальной ответственности Корпорации, выявленные на основе проведенного анализа социально-экономических показателей данного предприятия. Разработанная концепция общей социальной политики Корпорации следует принципам стандарта ISO 26000:2010 «Руководство по социальной ответственности».

В рамках исследования и проведения апробации более подробно рассмотрим только одно из направлений для социального проектирования, которое имеет наименьший суммарный балл по проведенной оценке состояния КСО АО «Корпорация ВСМПО-АВИСМА» и которое, на наш взгляд, является наиболее финансовоемким, - обеспеченность жильем сотрудников и населения моногорода. Концепция социального проекта по улучшению жилищно-коммунальных условий для достижения высокого уровня удовлетворенности сотрудников нематериальными, непроизводственными аспектами жизни на территории присутствия градообразующего предприятия представлена на $p u-$ сунке 24.

Экономическая обоснованность реализации социального проекта по улучшению жилищно-коммунальных условий для работников Корпорации: применение социальной политики неразрывно связано с ключевыми бизнес-процессами Корпорации, эффективностью осуществляемых видов деятельности. Для Корпорации приоритетно достижение долгосрочного устойчивого эффективного развития, нежели получение краткосрочных выгод и прибыли в ущерб достижению стратегически важных целей. 


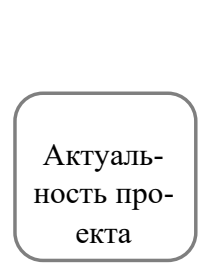

Цель проекта

Задачи проекта
Жилищная политика градообразующих предприятий имеет огромную социальную значимость. Данный проект для АО «Корпорация ВСМПО-АВИМА» актуален, поскольку численность населения моногорода и ССЧ работников Корпорации с каждым годом сокращается. Серьезный подход в решении жилищных вопросов работников позволит Корпорации привлечь молодых специалистов и удержать высококвалифицированных работников и работников остродефицитных профессий.

Увеличение численности населения г. Верхняя Салда на 600-800 человек, а также среднегодовой численности работников АО «Корпорация ВСМПО-АВИСМА» в рамках решения кадровых задач и в соответствии с условиями трудовых договоров к концу 2023 года за счет улучшения жилищно-коммунальных условий проживания в моногороде.

Увеличение объемов выпускаемой титановой продукции на 10\% по сравнению с 2019 г. за счет увеличения численности персонала и повышения их трудовой мотивации.

1. Создание условия для повышения уровня обеспеченности жильем семей;

2. Увеличение привлекательности финансирования жилищной сферы для сторонних инвесторов;

3. Разработка комплекса мер по государственной поддержке строительного бизнеса на территории моногорода;

4. Обеспечение заинтересованности населения в рассмотрении г. Верхняя Салда как территории своего проживания;

5. Субсидирование строительных компаний для проведения строительства жилых комплексов на территории моногорода;

6. Сотрудничество с ведущими вузами для заинтересованности молодых специалистов в работе на данной территории.

1. Строительство корпоративного жилого дома для работников Корпорации;

Содержание предполагаемой деятельности

2. Оказание целевой финансовой помощи на оплату первоначального взноса и по уплате процентов по программе ипотечного кредитования;

3. Компенсации стоимости найма жилья или аренда жилых помещений для сотрудников, проживающих за пределами моногорода

4. Компенсации работникам по строительству собственного жилья

5. Компенсагии по пемонтv кваптип мапоимуших семей
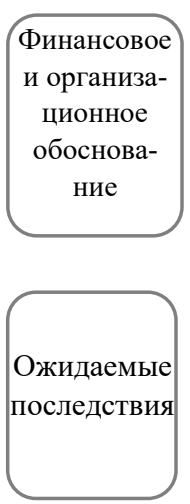

Источники финансирования социального проекта - собственные средства Корпорации и инвестиционная поддержка.

Для реализации проекта назначается руководитель проекта, создается проектная команда, в которую входят от 20 исполнителей проекта, менеджер социальных программ, бухгалтер

1. Закрепление положительной динамики численности населения, а также положительных демографических тенденций в г. Верхняя Салда за счет улучшения жилищных условий

2. Повышение среднегодовой численности работников АО «Корпорация ВСМПОАВИСМА»

3. Увеличение объемов выпускаемой продукции, а также финансовых показателей дея-

Рисунок 24. Кольности Корпорашии нальных условий для работников АО «Корпорация ВСМПО-АВИСМА» на 2020-2023 гг. 
2-й этап: оценка жизнеспособности социального проекта, основной задачей которой является установление степени риска при его реализации.

В рамках социального прогнозирования предположим три возможных варианта изменения ситуации в моногороде при реализации социального проекта по улучшению жилищно-коммунальных условий для сотрудников АО «Корпорация ВСМПО-АВИСМА» на 20202023 гг. (рис. 25). Рассмотрим один из значимых показателей, на который повлияет разрабатываемый социальный проект - численность населения моногорода. Поскольку, в свою очередь, данный показатель влияет на среднегодовую списочную численность работников градообразующего предприятия исследуемого моногорода, объемы выпускаемой продукции, а также на выручку и другие финансовые показатели организации.

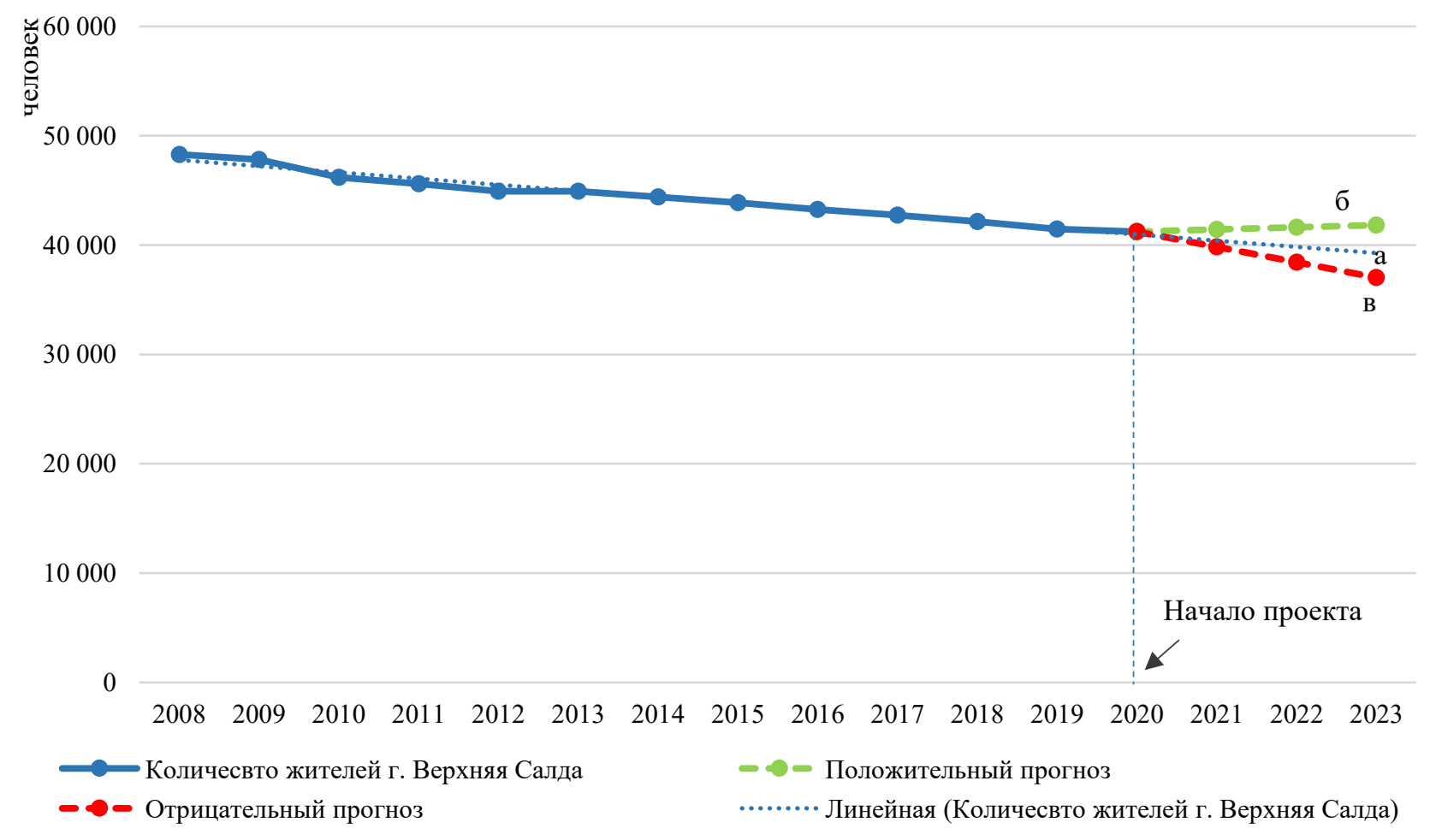

Рисунок 25. Социальный прогноз численности населения г. Верхняя Салда при реализации проекта по улучшению жилищно-коммунальных условий для сотрудников АО «Корпорация ВСМПО-АВИСМА» на 2020-2023 гг. 
Рассмотрим рисунок 25, на котором представлены возможные изменения показателя за время реализации проекта, и проанализируем три возможных варианта изменения этого показателя:

- реалистичный - после осуществления проекта показатель остается примерно на том же уровне в течение некоторого времени, т.е. численность населения моногорода продолжит сокращаться умеренными темпами или незначительно приостановит сокращение. Это жизнеспособность на уровне эффекта: предприятие не производит никаких действий по поддержанию показателя на нужном уровне, но эффект сохраняется;

- оптимистичный - во время осуществления социального проекта и после его окончания динамика численности населения г. Верхняя Салда с каждым годом увеличивается. Это - идеальный вариант: проект оказался жизнеспособным на уровне действия после окончания финансирования и завершения работы;

- пессимистичный - проект нежизнеспособен, поскольку после окончания проекта численность населения г. Верхняя Салда довольно быстро возвращается к прежнему значению и продолжит сокращаться усиленными темпами, то есть через некоторое, достаточно непродолжительное время эффект от реализации проекта просто исчезнет. Это может говорить о том, что, возможно, при анализе были допущены ошибки либо проект изначально ставил своей целью краткосрочное изменение ситуации без сохранения эффекта.

Таким образом, необходимо учитывать, что после окончания проекта есть определенные риски, связанные с ухудшением положения моногорода, а значит, и с осложнением ситуации в Корпорации.

3-й этап: при планировании проекта для установления ориентировочного перечня и порядка мероприятий реализации социального проекта воспользуемся таблицей, представленной в рамках разработанного инструментария (табл. 17). 


\section{Составление плана социального проекта по улучшению} жилищно-коммунальных условий для работников АО «Корпорация ВСМПО-АВИСМА» на 2020-2023 гг.

\begin{tabular}{|c|c|c|c|c|}
\hline $\begin{array}{l}\Pi / \\
\Pi\end{array}$ & $\begin{array}{l}\text { Содержание } \\
\text { мероприятий }\end{array}$ & $\begin{array}{l}\text { Ответствен- } \\
\text { ные за } \\
\text { исполнение }\end{array}$ & $\begin{array}{l}\text { Финансо- } \\
\text { вое обес- } \\
\text { печение, } \\
\text { млн руб. }\end{array}$ & $\begin{array}{c}\text { Сроки } \\
\text { исполне- } \\
\text { ния }\end{array}$ \\
\hline 1 & $\begin{array}{l}\text { Строительство 150-квартирного } \\
\text { жилого дома для постоянного } \\
\text { и временного проживания со- } \\
\text { трудников Корпорации }\end{array}$ & $\begin{array}{l}\text { Проектная ко- } \\
\text { манда, руко- } \\
\text { водитель про- } \\
\text { екта }\end{array}$ & 700 & $\begin{array}{l}2020-- \\
2023 \text { гг. }\end{array}$ \\
\hline 2 & $\begin{array}{l}\text { Оказание целевой финансовой } \\
\text { помощи на оплату первоначаль- } \\
\text { ного взноса по банковскому ипо- } \\
\text { течному жилищному кредиту ра- } \\
\text { ботникам Корпорации }\end{array}$ & $\begin{array}{l}\text { Бухгалтер, } \\
\text { менеджер со- } \\
\text { циальных } \\
\text { программ }\end{array}$ & 56 & $\begin{array}{c}2020- \\
2023 \text { гг. }\end{array}$ \\
\hline 3 & $\begin{array}{l}\text { Компенсация расходов по оплате } \\
\text { процентов по программе ипотеч- } \\
\text { ного кредитования }\end{array}$ & $\begin{array}{l}\text { Исполнитель } \\
\text { проекта, бух- } \\
\text { галтер }\end{array}$ & 40 & $\begin{array}{c}2020- \\
2023 \text { гг. }\end{array}$ \\
\hline 4 & $\begin{array}{l}\text { Компенсация стоимости найма } \\
\text { жилья или аренда жилых поме- } \\
\text { щений частного, государствен- } \\
\text { ного или муниципального жи- } \\
\text { лищного фонда }\end{array}$ & $\begin{array}{l}\text { Проектная ко- } \\
\text { манда, руко- } \\
\text { водитель про- } \\
\text { екта }\end{array}$ & 290 & $\begin{array}{l}2020- \\
2023 \text { гг. }\end{array}$ \\
\hline 5 & $\begin{array}{l}\text { Компенсации работникам } \\
\text { по строительству собственного } \\
\text { жилья }\end{array}$ & $\begin{array}{l}\text { Проектная ко- } \\
\text { манда, руко- } \\
\text { водитель про- } \\
\text { екта }\end{array}$ & 12 & $\begin{array}{c}2020- \\
2023 \text { гг. }\end{array}$ \\
\hline 6 & Расходы по оформлению сделок & $\begin{array}{l}\text { Исполнитель } \\
\text { проекта, бух- } \\
\text { галтер }\end{array}$ & 1 & $\begin{array}{c}2020- \\
2023 \text { гг. }\end{array}$ \\
\hline 7 & $\begin{array}{l}\text { Компенсация по ремонту квар- } \\
\text { тир малоимущих семей }\end{array}$ & $\begin{array}{l}\text { Проектная ко- } \\
\text { манда }\end{array}$ & 1 & $\begin{array}{c}2020- \\
2023 \text { гг. }\end{array}$ \\
\hline
\end{tabular}

Размер необходимого финансового обеспечения, представленный в таблице 14, определен исходя из рыночных цен строительного 
сектора и банковских услуг по приобретению и строительству жилья по УФО на конец 2019 г. - начало 2020 г. [73].

4-й этап: для составления бюджета при реализации социального проекта по улучшению жилищно-коммунальных условий для работников АО «Корпорация ВСМПО-АВИСМА» необходимо определить, сколько и какие ресурсы требуются.

Финансовое обеспечение по проекту составляет 1100 млн руб. а также для реализации социального проекта помимо финансовых ресурсов следует учитывать необходимость в материально-технических и человеческих ресурсах. В рамках проекта выявлено, что необходимое количество работников и специалистов в области строительства, консультирования по кредитованию и ипотечному жилью и других специалистов составляет 70 человек. Будем считать, что расходы по данным ресурсам включены в итоговую сумму финансового обеспечения проекта.

После разработки концепции, прогнозирования и планирования социального проектирования и составления бюджета помимо этого необходимы защита проекта, предварительный контроль, а также коррекция проекта и его реализация. В рамках апробации опустим данные этапы в силу невозможности их осуществления.

5-й этап: при завершении работ и ликвидации социального проекта необходимо провести заключительную оценку его предположительной реализации, которая представляет собой процесс сбора информации для оценки предполагаемых достигнутых результатов, объяснения того, посредством чего могут быть получены результаты и для лучшего планирования будущих проектов.

Поскольку эффективность социальных проектов проявляется в возможности достижения положительных и избежания отрицательных изменений на предприятии и в обществе с социальной точки зрения, рассмотрим предположительные изменения при осуществлении 
корпоративной социальной ответственности посредством социального проектирования. К числу положительных изменений при реализации разработанного социального проекта можно отнести следующие:

- увеличение среднегодовой численности работников градообразующего предприятия АО «Корпорация ВСМПО-АВИСМА» за счет решения жилищного вопроса сотрудников в сочетании с механизмами повышения мотивации к труду и закрепления персонала на рабочих местах;

- увеличение производительности труда на градообразующем предприятии;

- увеличение объемов выпуска продукции, а также выручки и других финансовых показателей Корпорации.

К числу предотвращаемых отрицательных изменений можно отнести:

- приостановление отрицательной тенденции в динамике численности населения моногорода Верхняя Салда;

- сокращение простоев оборудования на предприятии, связанных с нехваткой кадров.

Также после предположительной реализации социального проекта градообразующим предприятием произведем ориентировочный прогноз его экономической эффективности. Основываясь на анализе, проведенном в аналитической главе монографии, который показал, что при реализации корпоративной социальной ответственности и вложении денежных средств в работников градообразующего предприятия наблюдается слабая динамика изменений в обществе. Но именно при грамотном распределении денежных средств в КСО промышленными предприятиями в моногородах достигаются значительные положительные результаты их деятельности. 
Так, вложение финансовых средств в КСО в рамках разработанного проекта по улучшению жилищно-коммунальных условий в размере 1100 млн рублей позволит увеличить динамику численности населения моногорода к завершению реализации проекта на 2-3\% по сравнению с 2019 годом, что, в свою очередь, повлияет на среднегодовую численность работников Корпорации, которая увеличится на 5,5-7\% по сравнению с 2018 г.

Рост ССЧ работников Корпорации позволит увеличить объем реализации титановой продукции до 10\%. При этом прогнозная выручка от реализации продукции возрастет на 4-6\% по сравнению с 2018 г.

Из этого следует, что данный проект по улучшению жилищно-коммунальных условий позволит АО «Корпорация ВСМПО-АВИМА» привлечь молодых специалистов и удержать высококвалифицированных работников и работников остродефицитных профессий, что, в свою очередь, повлияет на финансово-хозяйственную деятельность предприятия, его конкурентоспособность и инвестиционную привлекательность.

Следовательно, разработанный инструментарий позволил провести апробацию, в рамках которой была проведена оценка КСО градообразующего предприятия АО «Корпорация ВСМПО-АВИСМА», выявлены ее слабые стороны, а также осуществлен выбор направления социального проектирования и инвестирования в КСО исследуемого предприятия.

Таким образом, предполагается, что разработанный инструментарий развития корпоративной социальной ответственности промышленных предприятий в моногородах позволит градообразующим предприятиям проводить самоанализ, оценивая социально-экономические показатели для дальнейшего выбора направлений социального проектирования и инвестирования в КСО. Все это положительно влияет на финансовохозяйственную деятельность предприятия, его конкурентоспособность и инвестиционную привлекательность самого градообразующего предприятия и моногорода в целом. 


\section{ЗАКЛЮЧЕНИЕ}

Социальная ответственность градообразующих предприятий имеет особую актуальность и значимость в плане сохранения социальной стабильности и развития целого населенного пункта. При этом заинтересованные стороны подобного предприятия в целом совпадают со стейкхолдерами любой другой организации. Отличия заключаются в том, насколько социальная ответственность предприятия влияет на стейкхолдеров. К примеру, в случае безответственного отношения к сотрудникам наиболее квалифицированные из них часто уезжают в другие города в поиске более благоприятных для жизни условий, при этом в последующем найти им замену в монопрофильных городах крайне сложно.

Благополучие и развитие моногородов, в которых осуществляют деятельность градообразующие предприятия, напрямую зависит от уровня осуществления корпоративной социальной ответственности и устойчивости его развития. Так, различные исследования российских моногородов доказывают, что большая часть подобных населенных пунктов находится в зоне риска или пограничной зоне, что говорит о необходимости достижения устойчивого развития предприятиями. В противном случае ситуация в моногородах будет только ухудшаться.

Рассмотренные в теоретической главе методические подходы к оценке эффективности КСО организации базируются на системных принципах, которые, в свою очередь, отвечают всем условиям устойчивого развития - социальной направленности деятельности, экономической стабильности и экологической безопасности, а также могут отвечать современной изменчивости российской экономики. Однако, несмотря на универсальность изученных методических подходов, практическая социальная деятельность предприятий требует формирования надежного инструментария для рационального обоснования 
социальных вложений. Также, проводя контент-анализ литературы, выяснилось, что на данный момент на практике не существует единого методического подхода к экономической оценке эффективности корпоративной социальной ответственности предприятий монопрофильных городов. Исходя из этого, рассмотренные методики послужили базой для исследования в рамках изучения и формирования авторского инструментария развития корпоративной социальной ответственности промышленных предприятий в моногородах и последующего инвестирования в КСО.

Проведенный в практической главе анализ показал, что территориально наибольшее сосредоточение моногородов в Российской Федерации происходит в Приволжском и Сибирском федеральных округах, в то время как в Уральском федеральном округе зарегистрирован максимальный процент населения округа, проживающего в моногородах. Такого рода география распределения градообразующих предприятий сложилась исторически и, вероятно, является вполне рациональной с точки зрения обеспечения ресурсами и оптимизации расходов в условиях экономической стабильности.

Для российских градообразующих предприятий одним из приоритетных направлений является сохранение окружающей среды и вложения в человеческий капитал (в том числе капитал здоровья и интеллектуальный капитал), однако основным барьером для осуществления подобной деятельности является высокий уровень затрат и сложность оценки их экономической эффективности. А также увеличение затрат промышленных градообразующих предприятий на корпоративную социальную ответственность не всегда дает положительный результат. Рост заболеваемости жителей моногородов, сокращение численности населения указывают на несовершенство системы КСО данных предприятий.

Таким образом, проведенный анализ подтвердил выдвинутую в теоретической главе гипотезу о том, что несмотря на существующее 
развитие КСО промышленных градообразующих предприятий, в моногородах сохраняется отрицательная динамика социально значимых показателей. Исходя из этого, подтвердилась необходимость в разработке инструментария развития корпоративной социальной ответственности промышленных предприятий моногородов, включающего в себя оценку социально-экономических показателей для последующего, более грамотного выбора направления инвестиций в КСО таких предприятий.

Проведенный анализ также показал, что существует необходимость в создании иного экономического подхода к оценке КСО и распределению имеющихся у градообразующих предприятий финансовых средств, уделяя больше внимания социальным аспектам как на предприятии, так и в самом моногороде. Исходя из этого, следует, что оценка эффективности КСО должна содержать все необходимые параметры социальной ответственности бизнеса в монопрофильных городах, а также должна базироваться не на произвольном наборе коэффициентов, а на показателях, характеризующих именно те аспекты деятельности, которые имеют существенное значение для социальной ответственности градообразующих предприятий. К таким показателям необходимо отнести:

- соотношение среднемесячной заработной платы работников градообразующего предприятия и в регионе;

- использование рабочих по квалификации;

- уровень технологической модернизации производства;

- стабильность кадров;

- условия производственного быта и повышения безопасности условий труда работников градообразующего предприятия;

- обеспеченность жильем сотрудников и населения моногорода;

- обеспеченность лечебно-оздоровительными учреждениями; 
- обеспеченность детскими учреждениями в моногороде;

- обеспеченность спортивными сооружениями, культурно-просветительскими учреждениями;

- уровень благоустройства территории монопрофильного муниципального образования и др.

Также в рамках оценки КСО организаций существует необходимость в построении некоего графика, который мог бы дать наглядное представление и зрительную оценку, как выглядит обобщенный критерий корпоративной социальной ответственности каждого градообразующего предприятия. Преимуществом данного метода является то, что он комплексный и учитывает наибольшее количество факторов, которые влияют на социальную ответственность организации.

Все это определило составляющие необходимого методического инструментария развития КСО промышленных предприятий в моногородах, основные этапы которого включают:

1-й этап: оценка эффективности корпоративной социальной ответственности градообразующего предприятия:

1) выбор и обоснование системы коэффициентов для оценки КСО, сбор данных по выбранным показателям и формирование матрицы исходных данных;

2) расчет показателей КСО градообразующего предприятия по выбранным параметрам, используя метод балльной оценки;

3) построение графика-радара социальной ответственности по рассчитанным показателям и расчет площади многоугольника КСО исследуемого предприятия;

4) анализ полученных результатов и сравнение площади многоугольника КСО предприятия с площадью оценочного круга; определение недостатков системы КСО градообразующего предприятия для последующего направления инвестиций; 
2-й этап: социальное проектирование по выявленным недостаткам системы КСО предприятия, которое включает следующие этапы:

1) разработка концепции проекта и оценка его жизнеспособности;

2) планирование проекта и составление бюджета;

3) защита проекта и принятие управленческих решений;

4) предварительный контроль и реализация мероприятий по проекту;

5) коррекция проекта и завершение работ.

Для подтверждения целесообразности и экономической эффективности разработанного инструментария проведена апробация, в рамках которой при оценке социально-экономических показателей градообразующего предприятия АО «Корпорация ВСМПОАВИСМА» были выявлены следующие слабые стороны системы КСО:

- повышение квалификации кадров;

- соотношение среднемесячной заработной платы работников градообразующего предприятия и в регионе;

- обеспеченность жильем сотрудников и населения моногорода;

- обеспеченность лечебно-оздоровительными учреждениями.

В связи с выявленными проблемами в КСО АО «Корпорация ВСМПО-АВИСМА» проведено социальное проектирование по одному из направлений, которое имеет наименьший суммарный балл по проведенной оценке КСО данного предприятия - обеспеченность жильем сотрудников и населения моногорода.

В результате предположительной реализации социального проекта исследуемым градообразующим предприятием произведен прогнозный расчет его экономической эффективности и выявлено, что вложение средств в КСО на обеспеченность жильем сотрудников 
и населения моногорода и улучшения жилищно-коммунальных условий в размере 1100 млн рублей позволит увеличить динамику численность населения моногорода Верхняя Салда к завершению реализации проекта на 2-3\% по сравнению с 2019 годом, что, в свою очередь, повлияет на среднегодовую численность работников Корпорации, которая увеличится на 5,5-7\% по сравнению с 2018 г. Рост ССЧ работников Корпорации позволит увеличить объем реализации титановой продукции до 10\%. При этом прогнозная выручка от реализации продукции возрастет на 4-6\% по сравнению с 2018 г.

Из этого следует, что данный проект по улучшению жилищнокоммунальных условий позволит АО «Корпорация ВСМПОАВИМА» привлечь молодых специалистов и удержать высококвалифицированных работников и работников остродефицитных профессий, что, в свою очередь, повлияет на финансово-хозяйственную деятельность предприятия, его конкурентоспособность и инвестиционную привлекательность.

Следовательно, разработанный инструментарий позволил провести апробацию, в рамках которой была проведена оценка КСО градообразующего предприятия АО «Корпорация ВСМПО-АВИСМА», выявлены ее слабые стороны, а также осуществлен выбор направления социального проектирования и инвестирования в КСО исследуемого предприятия.

Таким образом, предполагается, что разработанный инструментарий развития корпоративной социальной ответственности промышленных предприятий в моногородах позволит градообразующим предприятиям проводить самоанализ, оценивая социально-экономические показатели для дальнейшего выбора направлений социального проектирования и инвестирования в КСО. Все это положительно влияет на финансово-хозяйственную деятельность предприятия, его конкурентоспособность и инвестиционную привлекательность самого градообразующего предприятия и моногорода в целом. 


\section{СПИСОК ИСПОЛЬЗОВАННЫХ ИСТОЧНИКОВ}

1. Гонтарь Е. В. Социальные инвестиции как форма проявления корпоративной социальной ответственности бизнеса / Е. В. Гонтарь // Вестник Самарского государственного университета. - 2013. - No 4. C. 13-21.

2. Bowen H. Social Responsibilities of the Businessman / H. Bower // N. Y. : Harper \& Row. - 1953. - P. 6.

3. Carroll A. B. Corporate social responsibility: Evolution of definitional construct / A. B. Carroll // Business and Society. - 1999. - No 38 (3). - P. 268-295.

4. Carroll A. B. Corporate social responsibility: The centerpiece of competing and complementary frameworks / A. B. Carroll // Organizational dynamics. - N.Y. - 2015. - Vol. 44. - No 2. - P. 87-96.

5. Carroll A. B. The Pyramid of Corporate Social Responsibility: Toward the Moral Management of Organizational Stakeholders / A. B. Carroll // Business Horizons. - 1991. - July-August. - P. 42.

6. Creceru A. F. Social responsibility of the organization to customers through corporate communication / A. F. Creceru, V. Radulescu // Romanian Journal of Marketing. - No 3. - 2014. - P. 73-76.

7. Davis K. Business and Society: Environment and Responsibility / K. Davis, R. Blomstrom // N.Y. : McGrawHill. - 1975. - P. 174-175.

8. Windsor D. The Future of Corporate Social Responsibility / D. Windsor // The International Journal of Organizational Analysis. - 2011. Vol. 9, No 3. - P. 225-256. 
9. Зарецкий А.Д. Корпоративная социальная ответственность: мировая и отечественная практика : Учебное пособие / А. Д. Зарецкий, Т. Е. Иванова. - Краснодар : КСЭИ, 2012. - 129 с. - ISBN 978-591276-024-2.

10. Измайлова М. А. Социальная ответственность образовательных организаций в условиях экономики знаний / М. А. Измайлова // Вестник Алтайской академии экономики и права. - 2014. - No 5 (37). - C. 130-133.

11. Благов Ю. В. Генезис концепции корпоративной социальной ответственности / Ю. В. Благов // Вестник С. - Петербургского унта. - Сер. Менеджмент (2). - 2016. - С. 3-24.

12. Данилова О. В. Социальная ответственность бизнеса в системе рыночного хозяйства (теоретико-экономический аспект) : спец. 08.00 .05 «Экономика и управление народным хозяйством» : автореф. дис. ... д-ра экон. наук / Данилова Ольга Викторовна ; Финансовый ун-т при Правительстве РФ - Москва, 2013. - 25 с.

13. Корпоративная социальная ответственность : учебник и практикум для академического бакалавриата / Э. М. Коротков [и др.] ; под редакцией Э. М. Короткова. - 2-е изд. - Москва : Издательство Юрайт, 2019. - 429 с. - (Бакалавр. Академический курс). - ISBN 978-5-534-07332-4.

14. Робинс П. Менеджмент : Учебник / П. Робинс, М. Коултер / 6-е изд.; пер. с англ. - Москва : Изд. дом «Вильяме», 2002. - 880 с. ISBN 5-8459-0231-2.

15. Власть, бизнес, общество в регионах: неправильный треугольник : Учебник / Под ред. Н. С. Петрова, А. Е. Титкова ; Моск. Центр Карнеги. - Москва : Российская политическая энциклопедия (РОССПЭН), 2010. - 439 c. - ISBN 978-5-8243-1418-2. 
16. Шпотов Б. М. Деловая этика и менеджмент: современные подходы / Б. М. Шпотов // Проблемы теории и практики управления. - 2014. - No 1. - C. 89-94.

17. Фиглин Л. Модель управления качеством социальной ответственности организации / Л. Фиглин, В. Мосейко // Проблемы теории и практики управления. - 2013. - No 2. - С. 86-91.

18. Grayson D. Corporate Social Opportunity! Seven Steps to Make Corporate Social Responsibility Work for Your Business / D. Grayson, A. Hodges. // Greenleaf Publishing, 2014. - 390 p. - ISBN 1-874719-84-5.

19. Гришина Т. В. Эволюция теории и практики социальной ответственности предприятия: зарубежный опыт / Т. В. Гришина // Труд и социальные отношения. - 2014. - No 3. - С. 48-57.

20. Гришин А. И. Социальное предпринимательство и социальные проекты бизнеса в рамках концепции устойчивого развития / А. И. Гришин, М. С. Мельников, И. А. Строганов // Вестник Академии. -2015 . - No 1. - C. 9-15.

21. Патрушева Е. Моделирование ресурсных потоков компании и ее стейкхолдеров в процессе формирования совокупной стоимости / Е. Патрушева, К. Прохоров // Логистика. - 2011. - No 8 (61). - С. 6264.

22. Скобелева И. П. Стейкхолдеры - носители стратегических факторов успеха современных транспортных корпораций / И. П. Скобелева // Вестник государственного университета морского и речного флота им. адмирала С.О. Макарова. - 2014. - No 6 (28). - С. 139-143.

23. Одегов Ю. Г. Актуальные вопросы корпоративной социальной ответственности бизнеса / Ю. Г. Одегов, Е. В. Логинова // Нормирование и оплата труда в промышленности. - 2013. - No 2. - С. 17-29. 
24. Одегов Ю. Г. Кадровые проблемы российских предприятий: диагностика и пути решения / Ю. Г. Одегов // Вестник Омского университета. Серия: Экономика. - 2014. - No 2. - С. 5-10.

25. Воложанин К. Ю. По одежке встречают имидж как перспективный элемент коммуникационной политики организации в условиях кризиса / К. Ю. Воложанин // Креативная экономика. - 2015. No 6. - C. 59-67.

26. Вердюк О. В. Нормативное регулирование корпоративной социальной ответственности / О. В. Вердюк // Вестник СПбУ. Сер 5. - 2017. - No 2. C. $40-49$.

27. Об охране окружающей среды : федер. закон № 7-Ф3 : принят Гос. Думой 20 дек. 2001 г. : одобрен Советом Федерации 26 дек. 2001 $\Gamma$.

URL: http://www.consultant.ru/document/cons_doc_LAW_34823/ (дата обращения: 10.08.2020).

28. Конституция Российской Федерации : принята всенародным голосованием 12 дек. 1993 г. : текст с изм. на 21 июл. 2014 г. № 11ФКЗ.

URL:

http://www.consultant.ru/document/cons_doc_LAW_28399/ (дата обращения: 21.08.2020).

29. Трудовой кодекс Российской Федерации : закон. акт № 197Ф3 : принят Гос. Думой 21 дек. 2001 г. : одобрен Советом Федерации 26 дек. 2001 года : текст с изм. на 24 апр. 2020 г. - URL: http://www.consultant.ru/document/cons_doc_LAW_34683/ (дата обращения: 17.08.2020).

30. Об основах охраны здоровья граждан в Российской Федерации : федер. закон № 323-Ф3 : принят Гос. Думой 01 нояб. 2011 г. : одобрен Советом Федерации 09 нояб. 2011 г. - URL: http://www.consultant.ru/document/cons_doc_LAW_121895/ (дата обращения: 17.08.2020). 
31. Cochran F. L. Corporate Social Responsibility and Financial Performance / F. L. Cochran, L. Philip, A. Robert // Wood The Academy of Management Journal - 2017. - Vol. 27 - No. 1 - P. 43-44.

32. Calabrese A. A feedback-based model for CSR assessment and materiality analysis / A. Calabrese // Accounting Forum - 2015. - P. 312327.

33. Никитина Л. М. Алгоритм выбора инструментов для оценки корпоративной социальной ответственности / Л. М. Никитина, Д. В. Борзаков // Управленческие науки. - 2014. - No3 (12). - С. 24-28.

34. Гончаров С. Ф. Корпоративная социальная ответственность / С. Ф. Гончаров // М.: Дашков и Ко. - 2016. - С. 175-180.

35. Тульчинский Г. Л. Корпоративные социальные инвестиции и социальное партнерство: технологии и оценка эффективности : учеб. пособие / Г. Л. Тульчинский // Санкт-Петербургский филиал Нац. исслед. ун-та «Высшая школа экономики». - СПб. : Отдел оперативной полиграфии НИУ ВШЭ - Санкт-Петербург, 2012. - 236 с. ISBN 978-5-7598-0981-4.

36. Псарева Н. Ю. Оценка уровня развития корпоративной социальной ответственности / Н.Ю. Псарева // Сборник докладов научной конференции «Управленческие науки в современном мире». - Том 1. - М. : Изд.дом «Реальная экономика». - 2015. - С. 269-271.

37. Никитина Л. М. Проблемы теории и практики развития социальной ответственности бизнеса и корпоративного управления : учеб. пособие / Л. М. Никитина - Воронеж : ВГПУ, 2016. - 124 с.

38. Рейтинговое агентство Репутация : сайт. - URL: http://rareputation.ru/ (дата обращения 12.08.2020).

39. Перекрестов Д. Г. Корпоративная социальная ответственность: вопросы теории и практики : Учебник / Д. Г. Перекрестов, И. 
П. Поварич, В. А. Шабашев - Москва : Академия Естествознания, 2011. - 437 c. - ISBN: 978-5-91327-148-8.

40. Вайнхайрдт Й. Р. Корпоративная социальная ответственность: коммуникативные действия на внешнюю среду организаций государственного сектора / Й. Р. Вайнхайрдт // Современные исследования социальных проблем. - 2013. - No 10 (30). - С. 13-20.

41. Социальная ответственность и человеческий капитал предприятий в системе региональной социальной политики : монография / Е. В. Попова, Н. Р. Кельчевская, И. М. Черненко, С. А. Сироткин, И. С. Пелымская. - Москва : Креативная экономика, 2017. - 318 с. - ISBN 978-5-91292-186-5.

42. Стратегия муниципального развития моногородов высокотехнологического типа (на материалах городского округа Заречный Свердловской области) : монография / А. И. Кузьмин, Л. И. Воронина, Е. Н. Заборова, Г. Б. Иванцов [и др.]. / под науч. ред. проф. А. И. Кузьмина, доц. Л. И. Ворониной ; М-во образования и науки Рос. Федерации, Урал. федерал. ун-т. - Екатеринбург : Изд-во Урал. ун-та, 2014. - 181 c. - ISBN 978-5-7996-1379-2.

43. О несостоятельности (банкротстве) : федер. закон № 127-Ф3 : принят Гос. Думой 27 сент. 2002 г. : одобрен Советом Федерации 16 окт. $2002 \quad$ г. 2 URL: http://www.consultant.ru/document/cons_doc_LAW_39331/ (дата обращения: 17.08.2020).

44. Об утверждении перечня монопрофильных муниципальных образований Российской Федерации (моногородов) : Распоряжение Правительства РФ от 29 июл. 2014 № 1398-р : текст с изм. на 21 янв. 2020 $\Gamma$.

URL: http://www.consultant.ru/document/cons_doc_LAW_166540/(дата обращения: 21.08.2020). 
45. Официальный сайт Верхнесалдинского городского округа : офиц. сайт. - URL: http://v-salda.ru/ (дата обращения: 12.08.2020).

46. АО «Корпорация ВСМПО-АВИСМА» : офиц. сайт. - URL: http://www.vsmpo.ru/ru/ (дата обращения: 12.08.2020).

47. Численность работников всех организаций по моногородам // Федеральная служба государственной статистики : офиц. сайт. URL:

http://www.gks.ru/wps/wcm/connect/rosstat_main/rosstat/ru/statistics/wa ges/labour_force/ (дата обращения: 01.08.2020).

48. Официальный сайт городского округа Верхняя Пышма : офиц. сайт. - URL: http://movp.ru/ (дата обращения: 27.08.2020).

49. АO «Уралэлектромедь» : офиц. сайт. - URL: http://www.elem.ru/ru/ (дата обращения: 02.05.2020).

50. Аналитический доклад ИКСИ «Обзор российских моногородов» : сайт. - URL: https://icss.ru/vokrug-statistiki/obzor-rossijskixmonogorodov (дата обращения: 21.08.2020).

51. Управление Федеральной службы государственной статистики по Свердловской области и Курганской области «Свердловскстат» : офиц. сайт. - URL: https://sverdl.gks.ru/ (дата обращения: 01.08.2020).

52. Национальный регистр и библиотека нефинансовой отчетности. // Российский союз промышленников и предпринимателей : офиц. сайт. - URL: http://www.rspp.ru/simplepage/157 (дата обращения: 17.08.2020).

53. Попова Е. В. Инструментарий развития социальной ответственности промышленного предприятия : спец. 08.00.05 «Экономика и управление народным хозяйством» : дис. ... канд. экон. наук / Попова Екатерина Владимировна ; Сургутский государственный университет. - Сургут, 2015. - 162 с. 
54. Социальный отчет за 2018 год ПАО «Магнитогорский металлургический комбинат» : сайт. - URL: http://www.rspp.ru/document/1/5/c/5c730581b34046628b51567b8f81876 8.pdf (дата обращения: 12.08.2020).

55. Отчет о корпоративной социальной ответственности и устойчивости развития за 2018 год ПАО «Северсталь» : сайт. URL:

http://www.rspp.ru/document/1/2/9/292d62f62f4e6912c1821882590a073 2.pdf (дата обращения: 12.08.2020).

56. Социально экологический отчет за 2018 год ПАО «АК «АЛРОСА» : сайт. http://www.rspp.ru/document/1/7/5/75557173eed9e0e49677dd85537b8c7 8.pdf (дата обращения: 12.08.2020).

57. Corporate register of GRI : official website. - URL: http://www.corporateregister.com/ (дата обращения: 20.08.2020).

58. Годовой отчет за 2018 год АО «Корпорация «ВСМПОАВИСМА» : сайт. http://www.vsmpo.ru/doc_e/otchet/2018/god_2018.pdf (дата обращения: 19.08.2020).

59. Нефинансовые отчеты компаний, работающих в России: практика развития социальной отчетности. Аналитический обзор / Под общей ред. А. Н. Шохина - РСПП, Москва, 2006. - 108 с. - ISBN 5-98006-024-3.

60. Федеральная служба государственной статистики «Росстат» : офиц. сайт. - URL: https://sverdl.gks.ru/ (дата обращения: 19.08.2020).

61. Шитов В. Н. Комплексный подход к анализу конкурентоспособности предприятий / В.Н. Шитов, О.Ф. Цымбалист // Экономический анализ: теория и практика. - 2014. - No 13 (364). - С. 59-63. 
62. Луков В. А. Социальное проектирование : учеб. пособие / В. А. Луков. - 3-е изд., перераб. и доп. - Москва : Изд-во МГУ: Флинта, 2003. - 240 c. - ISBN 978-5-85085-747-9.

63. Смехов М. Неучебник по социальному проектированию / М. Смехов, О. Солдатова. - Москва : Педагогические технологии, 2008. $184 \mathrm{c}$.

64. Воробьева Д. Социальная ответственность бизнеса : сайт. URL: http:// www.socreklama.ru/ (дата обращения: 22.08.2020).

65. Курбатов В. И. Социальное проектирование: учеб. пособие / В. И. Курбатов, О. В. Курбатова. - Ростов-на-Дону : «Феникс», 2001. - 416 c. - ISBN 5-222-01636-6.

66. Остроух О. А. Основные этапы проведения мониторинга социальных проектов / О. А, Остроух, Е. Л. Соколова // Управление человеческими ресурсами - основа развития инновационной экономики. - 2016. - No 2. - С. 363-365.

67. Евдокимов Ф. И. Методические подходы к оценке социальной ответственности инвестиционных проектов / Ф. И. Евдокимов, В. Ф. Лысяков, Н. В. Розумная // Научные труды Донецкого национального технического университета. Серия : экономическая. $-2013 .-$ No 4 (46). - C. 132-140.

68. Вагизова Н. Г. Актуализация корпоративной социальной ответственности в нефтегазохимическом комплексе (на примере НГДУ «Ямашнефть») / Н. Г. Вагизова, Г. Х. Яруллина // Вестник Казанского технологического университета. - 2014. - Т. 17. No 13. - С. 318-320.

69. Марченко Е. М. Методические подходы к оценке эффективности инвестиций в социальные проекты / Е. М. Марченко, В. В. Глазкова // Экономический анализ: теория и практика. - 2014. - No 8 (359). - C. 35-42. 
70. Емельянов А. М. Оценка эффективности социальных проектов на основе индикаторов качества жизни населения / А. М. Емельянов, М. А. Исакин, Е. А. Исакина // Экономический анализ: теория и практика. - 2010. - No 21. - С. 43-52.

71. Гражданский кодекс Российской Федерации (часть первая) : закон. акт № 51-Ф3 : принят Гос. Думой 21 окт. 1994 г. - URL: http://www.consultant.ru/document/cons_doc_LAW_5142/ (дата обращения: 11.08.2020).

72. Об акционерных обществах : федер. закон № 208-Ф3 : принят Гос. Думой 24 нояб. 1995 : текст с изм. на 01 янв. 2020. - URL: http://www.consultant.ru/document/cons_doc_LAW_8743/ (дата обращения: 11.08.2020).

73. Министерство строительства и развития инфраструктуры Свердловской области : офиц. сайт. - URL: https://minstroy.midural.ru/ (дата обращения: 11.04.2020). 


\section{ПРИЛОЖЕНИЕ А}

Таблииа A.1

\section{Фрагмент Корпоративного социального пакета работникам ПАО «Корпорация «ВСМПО-АВИСМА» на 2019-2021 гг.}

\begin{tabular}{|c|c|}
\hline $\begin{array}{r}\text { Пункт } \\
\text { на } 201 \\
2021 \text { гс }\end{array}$ & $\begin{array}{c}\text { Минимальный социальный пакет - социальные льготы, предо- } \\
\text { ставляемые всем работникам }\end{array}$ \\
\hline 8.13 .1 & $\begin{array}{l}\text { Медицинское обслуживание работников за счет средств Работода- } \\
\text { теля: } \\
\text { - ВСМПО: в МУ МСЧ «Тирус» (в поликлинике, диагностическом } \\
\text { центре, ЦВМиР, здравпунктах, межцеховых оздоровительных цен- } \\
\text { трах); } \\
\text { - АВИСМА: в медико-санитарной части ООО «АВИСМА-МЕД», } \\
\text { кабинетах физиотерапевтического отделения ООО «АВИСМА- } \\
\text { МЕД» в цехах, здравпунктах. }\end{array}$ \\
\hline 8.13 .2 & $\begin{array}{l}\text { рилактической помощи в других ле- } \\
\text { еждениях в соответствии с догово- } \\
\text { сого страхования. }\end{array}$ \\
\hline 8.13 .3 & $\begin{array}{l}\text { емы оплаты труда, } \\
\text { ощим стаж работы } \\
1 \% \text { за каждый год } \\
\text { более } 25 \%\end{array}$ \\
\hline 8.13 .4 & $\begin{array}{l}\text { Реабилитационное лечение в профилактории «Чайка» ООО } \\
\text { «АВИСМА-МЕД» в соответствии с договором добровольного ме- } \\
\text { дицинского страхования работников, имеющих стаж работы не ме- } \\
\text { нее одного года }\end{array}$ \\
\hline 8.13 .5 & \\
\hline 8.13 .6 & отников до проходных и обратно \\
\hline 8.13 .7 & $\begin{array}{l}\text { Возможность пользования услугами на спортивных объектах Кор- } \\
\text { порации и посещения культурно-досуговых мероприятий, прово- } \\
\text { димых Корпорацией, на льготных условиях }\end{array}$ \\
\hline \multicolumn{2}{|c|}{$\begin{array}{c}\text { Адресная социальная поддержка - социальные льготы, предоставляемые в от- } \\
\text { дельных жизненных ситуациях }\end{array}$} \\
\hline 8.14 .1 & $\begin{array}{l}\text { я помощь на хозяйственное обзаве- } \\
\text { в запас после прохождения службы } \\
\text { ой Армии }\end{array}$ \\
\hline
\end{tabular}




\begin{tabular}{|c|c|}
\hline 8.14 .2 & $\begin{array}{l}\text { Единовременная материальная помощь иногородним выпускни- } \\
\text { кам учебных заведений начального, среднего и высшего професси- } \\
\text { онального образования, имеющим востребованные дефицитные } \\
\text { профессии и приглашенным на работу после прохождения произ- } \\
\text { водственной практики в Корпорации }\end{array}$ \\
\hline 8.14 .4 & $\begin{array}{l}\text { Социальный отпуск беременным женщинам, имеющим непрерыв- } \\
\text { ный стаж работы в Корпорации не менее двух лет и срок беремен- } \\
\text { ности не менее } 12 \text { недель }\end{array}$ \\
\hline 8.14 .5 & $\begin{array}{l}\text { Разовая премия в связи с } 25 \text {-летием непрерывной трудовой дея- } \\
\text { тельности в Корпорации при наличии ходатайства о поощрении } \\
\text { работника }\end{array}$ \\
\hline 8.14 .6 & $\begin{array}{l}\text { Разовая премия при увольнении в связи с выходом на пенсию } \\
\text { на общих или льготных основаниях, либо по инвалидности } \\
\text { при стаже работы в Корпорации } 12 \text { и более лет при наличии хода- } \\
\text { тайства о поощрении работника }\end{array}$ \\
\hline 8.14 .7 & $\begin{array}{l}\text { Единовременная материальная помощь при рождении ребенка од- } \\
\text { ному из родителей, если на момент рождения ребёнка родитель яв- } \\
\text { лялся работником Корпорации }\end{array}$ \\
\hline 8.14 .8 & $\begin{array}{l}\text { Ежемесячная материальная помощь работнику по уходу за ребен- } \\
\text { ком в возрасте от } 1,5 \text { до трёх лет, находящемуся в отпуске по уходу } \\
\text { за ребёнком в возрасте от } 1,5 \text { до трёх лет, при наличии стажа ра- } \\
\text { боты в Корпорации не менее двух лет }\end{array}$ \\
\hline 8.14 .9 & $\begin{array}{l}\text { Ежемесячная материальная помощь работникам, имеющим трех } \\
\text { и более детей на каждого ребенка до } 16 \text { лет (до } 18 \text { лет учащегося } \\
\text { или студента образовательного учреждения очной формы обуче- } \\
\text { ния), при наличии стажа работы в Корпорации не менее двух лет }\end{array}$ \\
\hline 8.14 .10 & $\begin{array}{l}\text { Ежемесячная материальная помощь работнику, имеющему ре- } \\
\text { бенка-инвалида в возрасте от трёх до } 18 \text { лет, нуждающегося в по- } \\
\text { стоянном уходе и не посещающего детский сад (школу) по меди- } \\
\text { цинским показаниям }\end{array}$ \\
\hline 8.14 .13 & $\begin{array}{l}\text { Беспроцентный денежный займ на возвратной основе на неотлож- } \\
\text { ные нужды, возникшие в случае пожара, потопа. Займ предостав- } \\
\text { ляется на основании решения комиссии по предоставлению зай- } \\
\text { мов с учётом нанесённого ущерба и материального положения ра- } \\
\text { ботника. Займ выдаётся в размере не более трёх средних месячных } \\
\text { заработных плат с погашением в течение одного года }\end{array}$ \\
\hline 8.14 .16 & $\begin{array}{l}\text { Беспроцентный денежный займ работникам АВИСМА на возврат- } \\
\text { ной основе для строительства и приобретения жилья. Займ выда- } \\
\text { ется работникам, состоящим в очереди на улучшение жилищных }\end{array}$ \\
\hline
\end{tabular}




\begin{tabular}{|c|c|}
\hline & $\begin{array}{l}\text { условий по решению жилищно-бытовой комиссии в пределах } \\
\text { утверждённых смет }\end{array}$ \\
\hline 8.14 .14 & $\begin{array}{l}\text { Единовременная выплата по возмещению морального вреда работ- } \\
\text { никам, получившим трудовое увечье, профессиональное заболев- } \\
\text { ние, связанное с работой, в случае установления процента утраты } \\
\text { трудоспособности }\end{array}$ \\
\hline $\begin{array}{c}\text { Пункт КД } \\
\text { на } 2019- \\
2021 \text { годы } \\
\end{array}$ & $\begin{array}{l}\text { Минимальный социальный пакет - социальные льготы, предо- } \\
\text { ставляемые всем работникам }\end{array}$ \\
\hline 8.14 .16 & $\begin{array}{l}\text { Предоставление жилых помещений на условиях найма/аренды ра- } \\
\text { ботникам, нуждающимся в улучшении жилищных условий, с ко- } \\
\text { торыми Корпорация заинтересована в сохранении и закреплении } \\
\text { трудовых отношений. Работники, вносящие значительный вклад } \\
\text { в развитие производства, имеют возможность выкупа жилых поме- } \\
\text { щений }\end{array}$ \\
\hline 8.14 .17 & $\begin{array}{l}\text { Кратковременный социальный отпуск для решения неотложных } \\
\text { социально-бытовых вопросов: для организации свадьбы, в связи } \\
\text { с рождением ребёнка (для отца), в связи с проводами сыновей в ар- } \\
\text { мию, в связи с похоронами близких родственников (родителей } \\
\text { (опекунов), супругов, детей (опекаемых)), родных братьев, сестёр, } \\
\text { бабушек, дедушек, внуков, внучек, родителей мужа (жены) }\end{array}$ \\
\hline 8.14 .18 & $\begin{array}{l}\text { Новогодние подарки детям работников в возрасте до } 14 \text { лет по со- } \\
\text { стоянию на } 31 \text { декабря текущего года. Подарки предоставляютяя } \\
\text { работникам, имеющим стаж не менее одного года на } 1 \text { декабря те- } \\
\text { кущего года }\end{array}$ \\
\hline 8.14 .19 & $\begin{array}{l}\text { Новогодние утренники для детей работников в возрасте от трёх } \\
\text { до } 12 \text { лет }\end{array}$ \\
\hline 8.14 .20 & $\begin{array}{l}\text { Путёвки на базу отдыха «Тирус», путёвки для детей в профилакто- } \\
\text { рий «Чайка» (г. Березники), в корпоративные детские лагеря «Ти- } \\
\text { рус», «Олимп», «Чайка» на льготных условиях }\end{array}$ \\
\hline 8.14 .13 & $\begin{array}{l}\text { Беспроцентный денежный займ на возвратной основе на неотлож- } \\
\text { ные нужды, возникшие в случае пожара, потопа. Займ предостав- } \\
\text { ляется на основании решения комиссии по предоставлению зай- } \\
\text { мов с учётом нанесённого ущерба и материального положения ра- } \\
\text { ботника. Займ выдаётся в размере не более трёх средних месячных } \\
\text { заработных плат с погашением в течение одного года }\end{array}$ \\
\hline
\end{tabular}




\section{ПРИЛОЖЕНИЕ Б} сти Корпорации

$\checkmark$ Участие в КСО инициативах

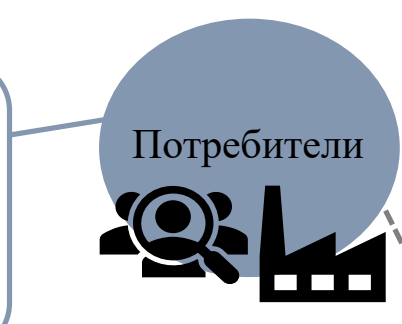

Рост инвестиционной привлекательности

$\checkmark$ Минимизация нефинансовых рисков

Повышение квалификации кадров

сти при реализации совместных проектов

$\checkmark$ Устойчивые взаимоотношения с $\quad \mathrm{AO}$ «Корпорация ВСМПО-АВИСМА»

$\checkmark$ Повышение качества управления компанией

$\checkmark$ Повышение эффективности деятельности предприятия в рамках устойчивого развития

$\checkmark$ Улучшение социальной репутации компании

$\checkmark$ Повышение качества взаимодействия со стейкхолдерами

$\checkmark$ Устойчивые взаимоотношения с поставщиками и партнерами

$\checkmark$ Увеличение финансовых показателей

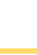

Рисунок Б.1. Концепция социальной политики АО «Корпорация ВСМПО-АВИСМА» 


\section{СВЕДЕНИЯ ОБ АВТОРАХ}

Кельчевская Наталья Рэмовна - доктор экономических наук, профессор, Заслуженный работник Высшей школы РФ, зав. кафедрой экономики и управления на металлургических и машиностроительных предприятиях Института экономики и управления Уральского федерального университета.

Пелымская Ирина Сергеевна - кандидат экономических наук, доцент, доцент кафедры экономики и управления на металлургических и машиностроительных предприятиях Института экономики и управления Уральского федерального университета. 
Кельчевская Наталья Рэмовна

Пелымская Ирина Сергеевна

\title{
КОРПОРАТИВНАЯ СОЦИАЛЬНАЯ ОТВЕТСТВЕННОСТЬ ПРОМЫШЛЕННЫХ ПРЕДПРИЯТИЙ В МОНОГОРОДАХ
}

\author{
монография \\ Выпускающий редактор: Цветкова А.В. \\ Корректор: Бородина Л.В. \\ Верстальщик: Журавлева В.А. \\ Издание научных монографий: \\ mono@1economic.ru \\ +74956486241 \\ Информация для авторов: \\ www.1 economic.ru
}

Усл. печ. л. 9,42. Тираж 500 экз.

Подписано в печать 06.11.2020

Формат: 60x84/16

Отпечатано: ПАО «Т8 Издательские Технологии»

109316 Москва, Волгоградский проспект, дом 42, корпус 5

Тел.: +7 (499) 322-38-30 